\title{
In vitro gyökér alapú regenerációs rendszer Arabidopsis-ban
}

Doktori (Ph.D.) értekezés

\section{Bernula Dóra}

\author{
Témavezetök: \\ Prof. Dr. Fehér Attila \\ tanszékvezető egyetemi tanár

\section{Pichererné Dr. Gémes Katalin} \\ egyetemi adjunktus
}

\author{
Szegedi Biológiai Kutatóközpont \\ Növénybiológiai Intézet \\ Növényi Fejlődés és Alkalmazkodás Molekuláris Szabályozása Kutatóegység \\ Növényi Morfogenezis Szabályozása Csoport \\ Szegedi Tudományegyetem \\ Természettudományi és Informatikai Kar \\ Biológia Doktori Iskola
}

Szeged

2020 


\section{Tartalom}

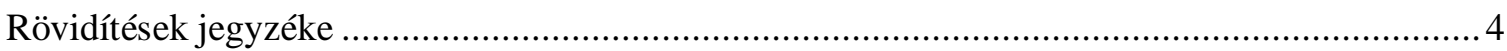

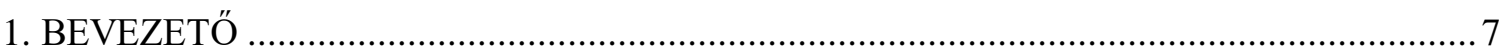

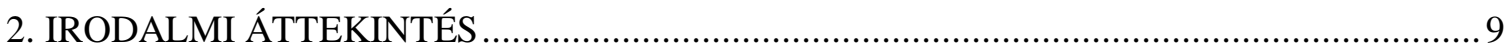

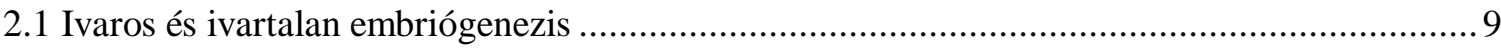

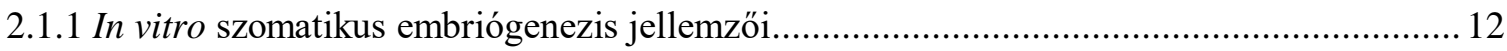

2.1.2 In vitro szomatikus embriógenezis gyakorlati alkalmazása............................................ 14

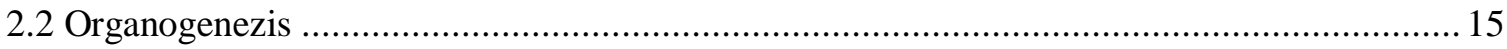

2.3 A növényi hormonok szerepe a regenerációs folyamatokban ......................................... 16

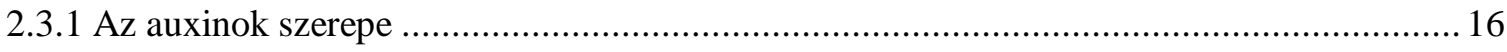

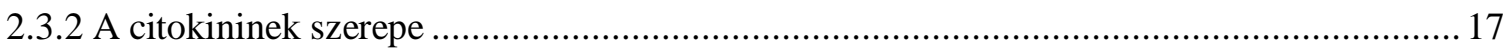

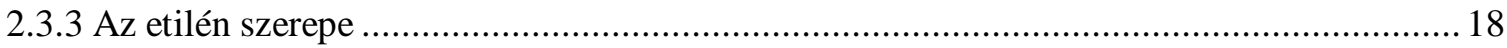

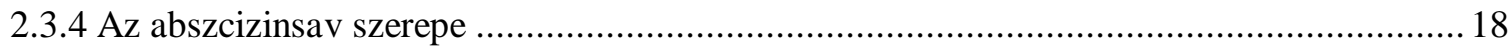

2.4 Transzkripciós faktorok szerepe az Arabidopsis in vitro regenerációjában .......................... 19

2.4.1 A SE során szerepet játszó főbb transzkripciós faktorok ............................................... 19

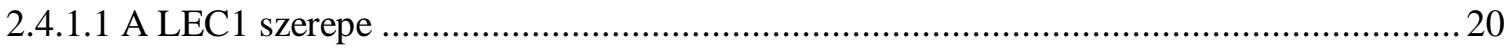

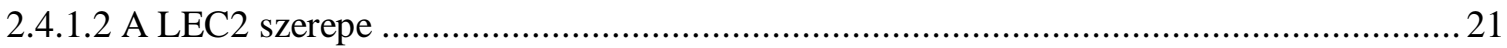

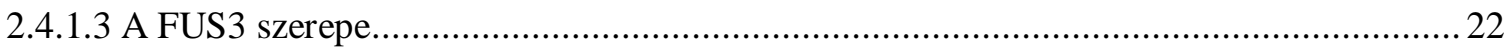

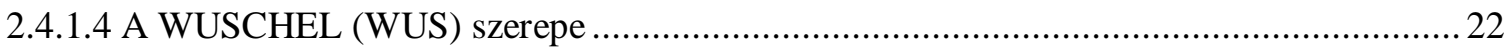

2.4.1.5 A WOUND-INDUCED DEDIFFERENTIATION 1 (WIND1) szerepe ......................... 24

2.4.2 A de novo hajtás organogenezis során szerepet játszó fő́bb transzkripciós faktorok ...........25

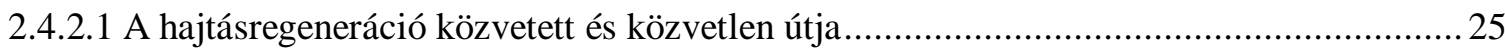

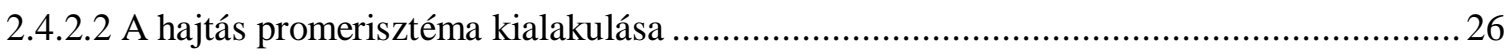

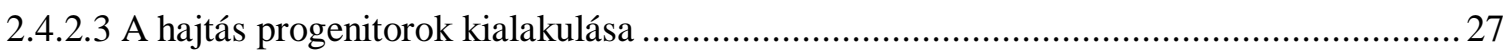

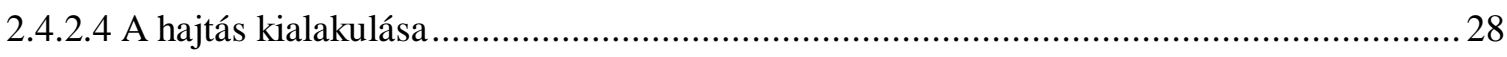

2.5 Arabidopsis thaliana, mint a regeneráció modellnövénye ............................................... 29

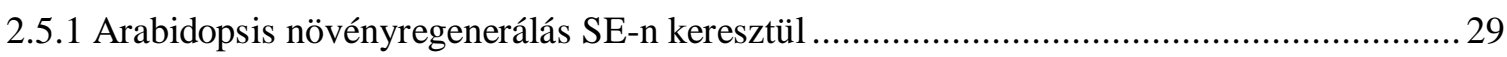

2.5.2 Arabidopsis növényregenerálás organogenezisen keresztül ........................................... 31

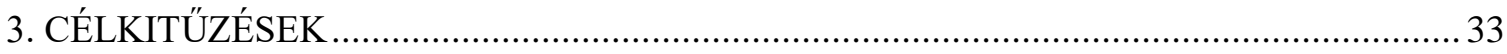

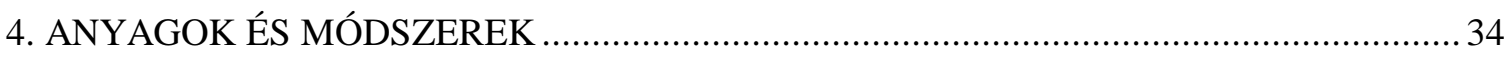

4.1 A kísérleti növény bemutatása, in vitro szövettenyészetek ............................................. 34

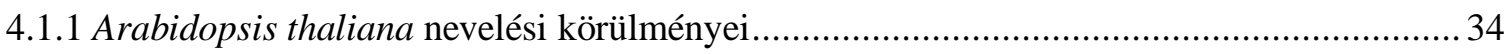

4.1.1.1 Vad típusú növények nevelése, elökészítése ............................................................... 34

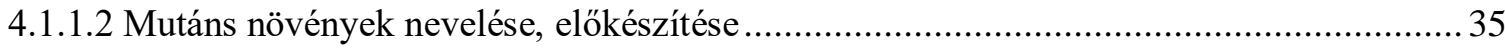


4.1.2 In vitro gyökér alapú regenerációs rendszer ............................................................. 35

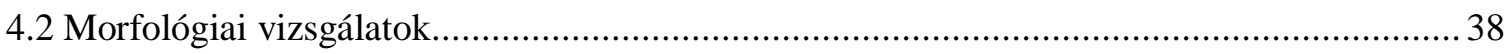

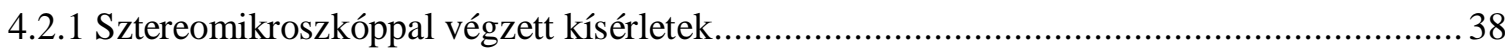

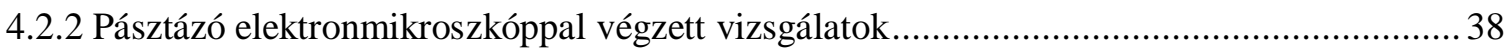

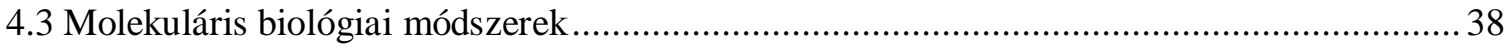

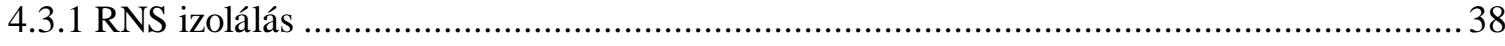

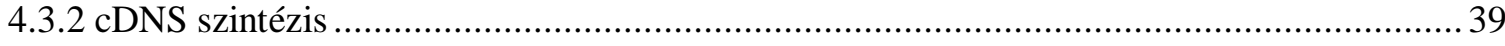

4.3.3 Valós idejü kvantitatív polimeráz láncreakció (RT-QPCR) …….......................................39

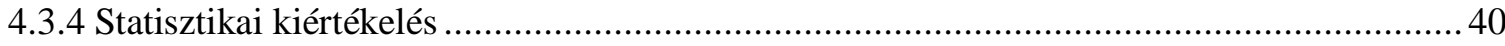

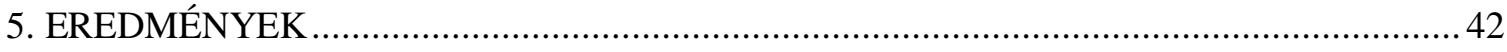

5.1 Arabidopsis in vitro gyökér alapú regenerációs rendszer .....................................................42

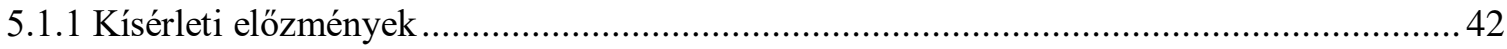

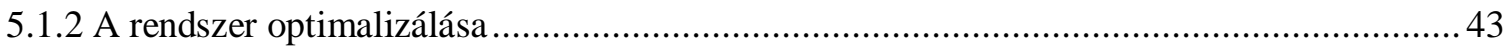

5.1.3 A citokinin megfelelő időben történő eltávolítása két regenerációs útvonal megjelenését

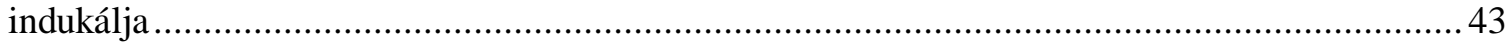

5.1.3.1 Sztereomikroszkóppal végzett morfológiai vizsgálatok ............................................. 43

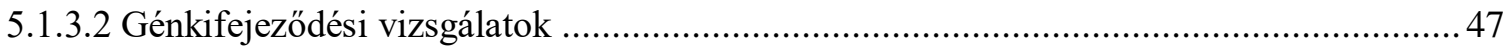

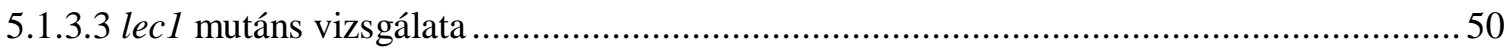

5.1.4 A hajtáseredetủ auxin hatása a gyökér regenerációs folyamataira ......................................53

5.1.4.1 Sztereomikroszkóppal végzett morfológiai vizsgálatok ............................................. 53

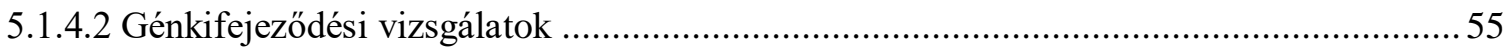

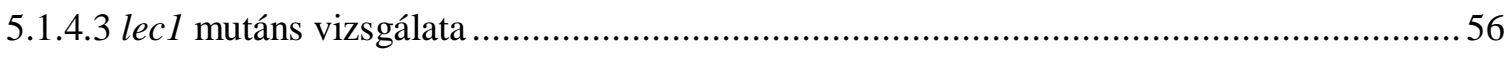

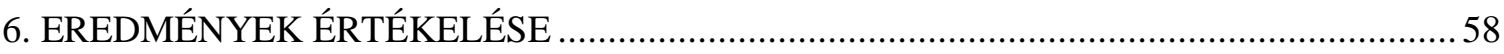

6.1 A citokinin megfelelő időben történő eltávolítása két regenerációs útvonal megjelenését

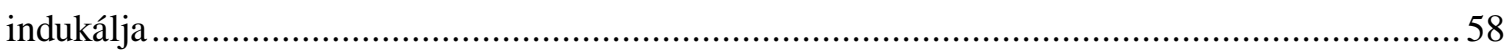

6.2 A hajtáseredetủ auxin gátló hatással van a gyökér regenerációs folyamataira ...................... 60

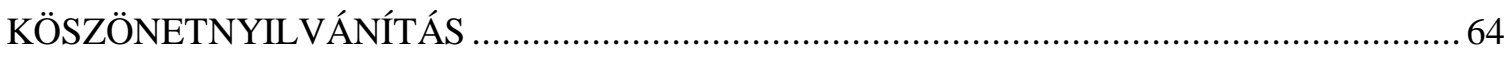

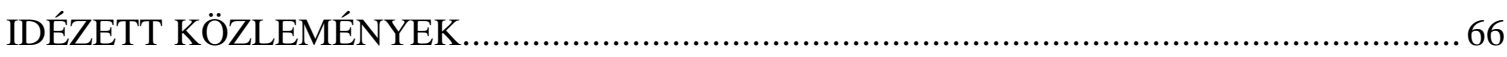

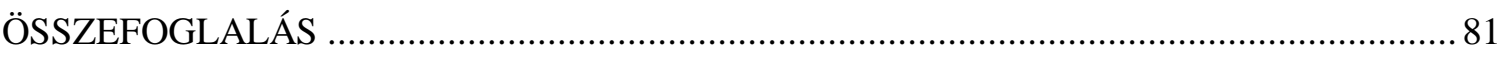

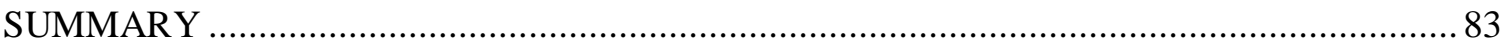

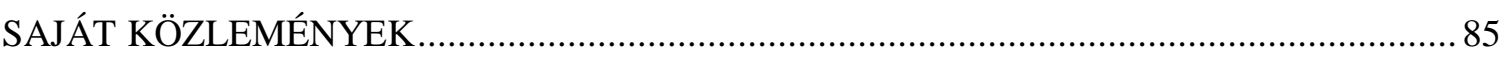

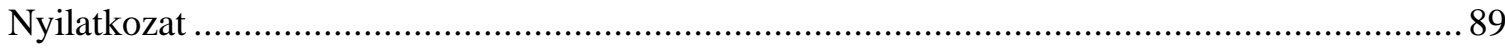




\section{Rövidítések jegyzéke}

\begin{tabular}{|c|c|}
\hline $2,4-\mathrm{D}$ & 2,4-diklórfenoxi-ecetsav \\
\hline $2 \mathrm{iP}$ & $\mathrm{N}^{6}$-(2-izopentenil)-adenin \\
\hline $35 S$ & karfiolmozaik vírus $35 S$ RNS génjének promótere \\
\hline$A B A 2$ & ABA DEFICIENT 2 \\
\hline $\mathrm{ABS}$ & abszcizinsav \\
\hline $\mathrm{ACC}$ & 1-aminociklopropán-1-karbonsav \\
\hline AHP6 & ARABIDOPSIS PHOSPHOTRANSMITTER 6 \\
\hline ALF4 & ABERRANT LATERAL ROOT FORMATION 4 \\
\hline ANOVA & Analysis of variance (varianciaanalízis) \\
\hline$A P 2 / E R F$ & APETALA2/Ethylene Responsive Factor \\
\hline ARM I & Arabidopsis regeneration media I (Arabidopsis regeneráló táptalaj I) \\
\hline ARM IIr & Arabidopsis regeneration media IIr (Arabidopsis regeneráló táptalaj IIr) \\
\hline ARR1 & ARABIDOPSIS RESPONSE REGULATOR 1 \\
\hline ARR2 & ARABIDOPSIS RESPONSE REGULATOR 2 \\
\hline ARR5 & ARABIDOPSIS RESPONSE REGULATOR 5 \\
\hline ARR6 & ARABIDOPSIS RESPONSE REGULATOR 6 \\
\hline$A R R 7$ & ARABIDOPSIS RESPONSE REGULATOR 7 \\
\hline ARR10 & ARABIDOPSIS RESPONSE REGULATOR 10 \\
\hline ARR12 & ARABIDOPSIS RESPONSE REGULATOR 12 \\
\hline ARR15 & ARABIDOPSIS RESPONSE REGULATOR 15 \\
\hline At & Arabidopsis thaliana \\
\hline ATHB8 & ARABIDOPSIS THALIANA HOMEOBOX GENE 8 \\
\hline $\mathrm{BA}$ & 6-benziladenin \\
\hline cDNS & komplementer egyszálú DNS \\
\hline CLV1 & CLAVATA 1 \\
\hline CLV2 & CLAVATA 2 \\
\hline CLV3 & CLAVATA 3 \\
\hline Col & Columbia (ökotípus) \\
\hline$C U C 1$ & CUP-SHAPED COTYLEDON 1 \\
\hline$C U C 2$ & CUP-SHAPED COTYLEDON 2 \\
\hline$D R N$ & DORNRÖSCHEN \\
\hline$D R N L$ & $D R N-L I K E$ \\
\hline
\end{tabular}




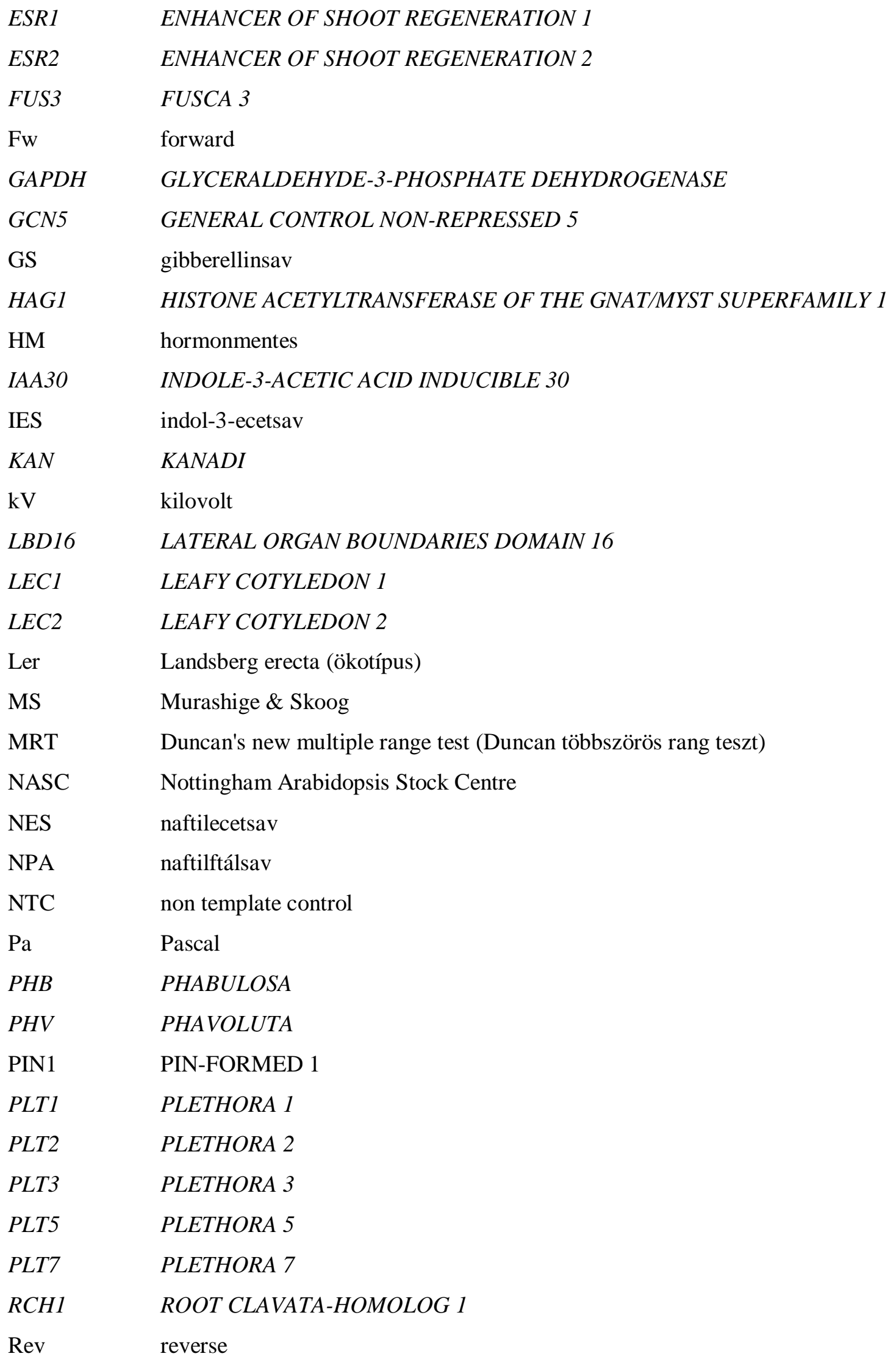




$\begin{array}{ll}\text { REV } & \text { REVOLUTA } \\ \text { RT-QPCR } & \text { valós idejü kvantitatív polimeráz láncreakció } \\ \text { SCR } & \text { SCARECROW } \\ \text { SHR } & \text { SHORTROOT } \\ \text { SE } & \text { szomatikus embriógenezis } \\ \text { STM } & \text { SHOOT MERISTEMLESS } \\ \text { TAA1 } & \text { TRYPTOPHAN AMINOTRANSFERASE OF ARABIDOPSIS 1 } \\ \text { TAIR } & \text { The Arabidopsis Information Resource } \\ \text { TF } & \text { transzkripciós faktor } \\ \text { TIBA } & 2,3,5 \text {-trijód-benzoesav } \\ \text { UBQ1 } & \text { UBIQUITIN 1 } \\ \text { WIND1 } & \text { WOUND-INDUCED DEDIFFERENTIATION 1 } \\ \text { WOX5 } & \text { WUS-RELATED HOMEOBOX 5 } \\ \text { WOX11 } & \text { WUS-RELATED HOMEOBOX 11 } \\ \text { WUS } & \text { WUSCHEL } \\ \text { YUC } & \text { YUCCA } \\ \text { YUC2 } & \text { YUCCA 2 } \\ \text { YUC4 } & \text { YUCCA 4 } \\ \text { ZE } & \text { zigotikus embriógenezis } \\ \end{array}$




\section{BEVEZETŐ}

Az elmúlt évtizedekben számos in vitro regenerációs rendszert dolgoztak ki a növények vegetatív szaporítására. Ezek egy része a szomatikus embriógenezist (SE), míg más részük a de novo organogenezist veszi alapul. Mindkét folyamat történhet direkt vagy indirekt módon. Ha a regeneráció indirekt módon történik, akkor kallusz kialakulásán keresztül, míg ha direkt módon, akkor kallusz kialakulása nélkül, egy vagy néhány sejtből indul el a folyamat.

A regeneráció sikerességét több tényező is befolyásolja, úgymint a megfelelő explantum megléte, a környezeti körülmények, valamint a táptalaj megfelelö összetétele. A stressz és a növényi hormonok, elsősorban az auxin és a citokinin fontosságát a növényi regenerációs folyamatokban több tanulmányban leírták. Az auxin elsősorban a gyökér regenerációját, a citokinin a hajtásregenerációját serkenti, kiegyenlített együttes hatásuk folyamatosan osztódó kallusztenyészetet eredményez.

A szomatikus embriógenezis elindításában a hormonok közül a legjelentősebb az auxinok szerepe. A citokininek hatása a folyamatra változó. A legtöbb kísérleti rendszerben az alacsony citokinin koncentráció kedvez a SE-nek, míg más esetekben a külső citokinin kezelés gátolja azt.

Az elmúlt években számos olyan transzkripciós faktort sikerült azonosítani, melyek részt vesznek az embrióképződés folyamatában. A LEC1, a LEC2 és a FUS3 transzkripciós faktorok egymással kölcsönhatásban szabályozzák a mag érése mellett az embrió identitását és az esetek egy részében a SE folyamatát is.

A regenerációs folyamatok sebzés hatására is indukálódhatnak. A sebzés során az egyik elsőként aktiválódó transzkripciós faktor a WIND1. A sebzésről és a sebzés által indukált WIND1ről kimutatták, hogy központi szerepük van a gyökér explantumok megnövekedett regenerációs potenciáljában.

A növényi regenerációs folyamatok megértéséhez nagymértékben hozzájárultak és hozzájárulhatnak azok a kutatások, melyeket a modellnövény Arabidopsis thaliana (lúdfü) segítségével végeznek, mivel e növény kapcsán nagy mennyiségben állnak rendelkezésre különféle mutáns és transzgénikus vonalak, markerek, génkonstrukciók, ellenanyagok és specifikus információk. Azonban ezek kihasználására a SE kutatásában eddig korlátozott volt a lehetőség, mert nem állt rendelkezésre egy olyan hatékony és rutinszerủen használható sejt- és szövettenyésztési kísérleti rendszer, ami ezt lehetővé tette volna. Bár az Arabidopsis érett/éretlen zigotikus embriók tenyésztésén alapuló SE tanulmányozása jelentős betekintést nyújtott ebbe a folyamatba, a megállapítások általánosítása céljából más explantumok használata (lehetőleg azok, amelyek a 
zigotikus embrióknál differenciáltabb szövetet tartalmaznak) hasznos lenne. A múlt század 90-es éveinek elején Arabidopsis gyökértenyészeteken végzett munkák eredményeként SE útján történő regenerációról vagy legalábbis szomatikus embriószerü struktúrák megjelenéséről számoltak be.

Mindezek tükrében munkánk során célunk volt egy olyan hatékony in vitro gyökér alapú regenerációs kísérleti rendszer kidolgozása, mely a jelenleg elterjedt zigotikus embriók tenyésztésén alapuló rendszernél egyszerübb és megfelelő minőségü, mennyiségü kísérleti anyagot szolgáltat, továbbá lehetővé teszi az organogenezis és a SE kezdeti lépéseinek tanulmányozását és összehasonlítását Arabidopsis thaliana növényen. 


\section{IRODALMI ÁTTEKINTÉS}

A növények környezetüktől való függésük miatt figyelemre méltó fejlődési rugalmassággal rendelkeznek, ami elősegíti alkalmazkodásukat a környezeti feltételek változásához. Folyamatosan ki vannak téve sérüléseknek egyrészt a kártevők támadásai, másrészt a környezeti ártalmak (fagy, viharok, tűz) révén. Ezek túlélését lenyügöző regenerációs képességük teszi lehetővé (Fehér, 2015). A magasabbrendü növények esetén három fő regenerációs folyamatot különböztetünk meg: a szöveti regenerációt, ami a sérült szövet vagy hiányzó szövetdarab regenerációja, a de novo organogenezist, ami egy teljes szerv fejlődése és a szomatikus embriógenezist (SE), melynek során egy vagy több testi sejt képes embrióvá fejlődni, majd kialakítani a teljes növényt (Xu és Huang, 2014; Fehér és mtsai., 2016; Fehér, 2019).

\subsection{Ivaros és ivartalan embriógenezis}

A növények életciklusának kezdeti szakasza az embriófejlődés (embriógenezis), mely az embrió előre programozott, meghatározott eseményeket adott sorrendben magába foglaló fejlődése. Az embriógenezisnek növényekben két fö típusa különböztethető meg: az ivaros és az ivartalan embriógenezis.

Ivaros embriógenezis során a haploid ivarsejtek egyesülésének eredményeképpen kialakul a diploid zigóta, amely ezt követően embrióvá fejlődik. Ezt a folyamatot zigotikus embriógenezisnek (ZE) is nevezik. Az embriófejlődés aszimmetrikus sejtosztódással kezdődik. A nagyobb bazális sejtből alakul ki a szuszpenzor, a kisebb apikális sejtből pedig az embrió differenciálódik. Az embrió fejlődése ezt követően jellegzetes morfológiai stádiumokkal jellemezhető. A gömb (globuláris) stádiumot a szív, majd végül a torpedó stádium követi (Capron és mtsai., 2009) (1. ábra). 


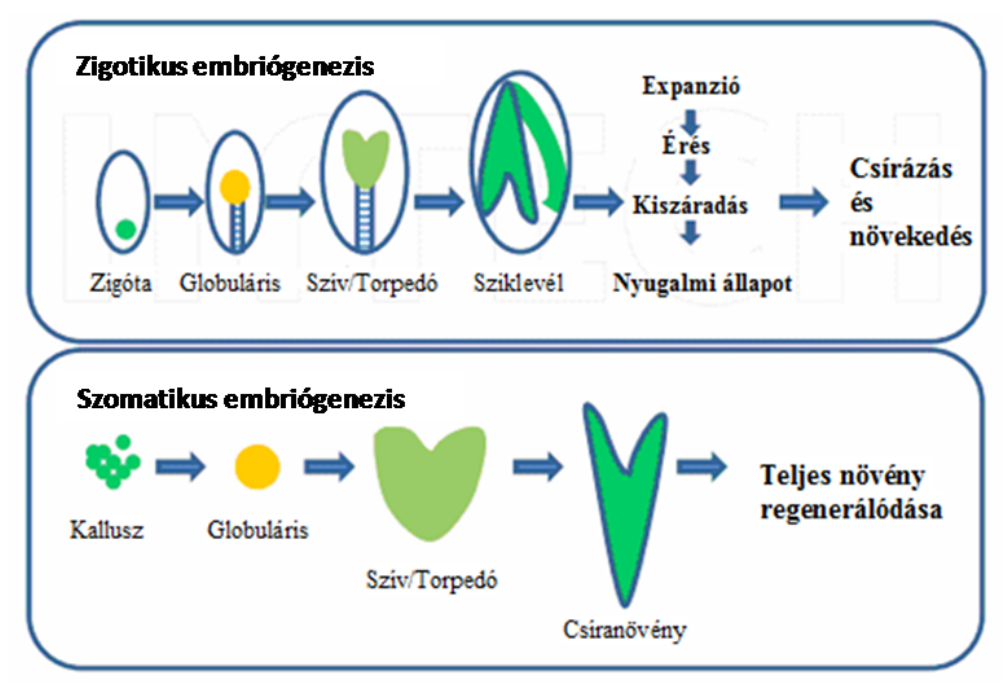

1. ábra: Zigotikus és indirekt szomatikus embriógenezis növényekben (Solís-Ramos és mtsai., 2012 alapján).

Növényekben az embriógenezis elindítása nem korlátozódik a megtermékenyített petesejtre. A növények ivartalan embriógenezise során nincs szükség sem meiózisra, sem pedig a petesejt megtermékenyítésére (Fehér, 2015). Az ivartalan embriók fejlődése nagyon hasonlít a zigotikus embriók fejlődéséhez mind morfológiailag, mind fiziológiailag (Solís-Ramos és mtsai., 2012). A fejlődő embrió fokozatos szerveződésének eredményeképpen ezekben az esetekben is előbb egy soksejtes gömb alak (globuláris stádium) jön létre, majd az embrió bipolárissá válik, kialakul a szív, majd a torpedó stádium (Heszky, 2003; Solís-Ramos és mtsai., 2012) (1. ábra). Mind az ivaros, mind az ivartalan embriógenezisre sor kerülhet természetes (in planta) és mesterséges (in vitro) körülmények között is. A növényi embriógenezis különböző útvonalait a 2. ábra mutatja be vázlatosan.

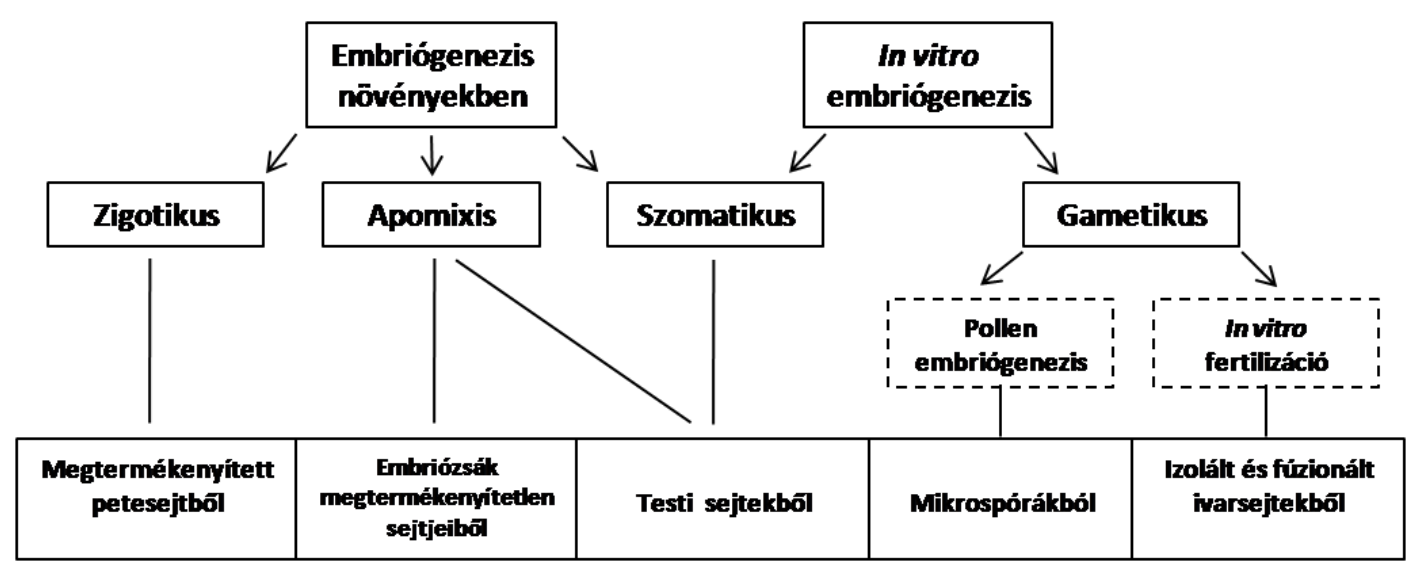

2. ábra: Embriógenezis típusai növényekben (Fehér, 2005 alapján). 
Az ivartalan embriógenezisnek egyik természetes formája az apomixis. Apomixisről akkor beszélhetünk, amikor megtermékenyítés hiányában is megindul a magfejlődés, azaz a mag aszexuálisan alakul ki. Apomixis során vagy diploid embriózsák jön létre és a diploid petesejt partenogenetikusan embrióvá fejlődik vagy a nucellusz diploid sejtjeiből indul el járulékos embriófejlődés (Hand és Koltunow, 2014).

A hím gametofiton sejtjeiből kiinduló embriófejlődés (androgenezis) ritkán zajlik le spontán módon, általában valamilyen kiváltó hatás szükséges az elindításához. Ez a hatás az esetek túlnyomó részében valamilyen stresszkezelést jelent, aminek a teljes növényt, a virágot, a bimbót, a portokot vagy az izolált mikrospórákat teszik ki (Maraschin és mtsai., 2005). Legelterjedtebb az izolált portokok vagy mikrospórák kezelésével kiváltott in vitro androgenezis, melyet elterjedten használnak a növénynemesítők haploid/dihaploid növény vonalak elóállítására (Basu és mtsai., 2011).

A SE jelensége a természetben spontán is előfordul bizonyos fajoknál, például az álelevenszülö Kalanchoe, Bryophillum fajoknál (Yarbrough, 1932), ahol a levelek szélén fejlödnek embriók, majd azokból növények. A folyamat azonban számos növényfaj esetében csak mesterségesen, in vitro körülmények között váltható ki. 


\subsubsection{In vitro szomatikus embriógenezis jellemzői}

A SE az ivartalan embriógenezis azon formája, mely során különböző indukciós tényezők (növényi hormonok, stressz) hatására a differenciált testi sejtek embrióvá fejlődnek. In vitro embriógenezist először répában (Daucus carota) írtak le 1958-ban (Steward és mtsai., 1958; Reinert, 1959), azóta azonban már számos más növényfaj esetében is sikerült SE elindítására alkalmas körülményeket kidolgozni. Az in vitro tenyésztési rendszereknek köszönhetően olyan sejtekből is kifejlődhetnek embriók, melyekből természetes körülmények között sosem fejlődnének ki. Ezen tenyésztés magába foglalja a növény egy részének (explantum) mesterséges tápközegbe való helyezését, aminek következtében a sejtek felszabadulnak az addigi differenciációs kényszer alól (“dedifferenciálódnak”), majd ezáltal képessé válnak szignálokra reagálva új egyedfejlődési program elindítására és a kompetensek elindíthatják az embriógenezis programját (Burgess, 1985). A tenyészetekbe helyezett explantumok és sejtjeik többféle útvonalon fejlődhetnek embrióvá (Fehér és mtsai., 2016; Fehér, 2019). Az in vitro SE-nek két fő formája különíthető el. Indirekt, más néven közvetett embriógenezis során a differenciált testi sejtből először kallusz szövet (proembriogén sejttömeg) képződik, amely megfelelő körülmények hatására (hormonális grádiensek kialakulásának eredményeként) hajtás- és gyökérmerisztémává szerveződve kialakítja a szomatikus embrió struktúráját (Fehér és mtsai., 2016). Ezzel szemben direkt, más néven közvetlen SE esetén a differenciált sejtből közvetlenül indul el az embriófejlődés genetikai programja (Gaj, 2004; Fehér, 2015). Ezen útvonalakat a 3. ábra szemlélteti vázlatosan. 


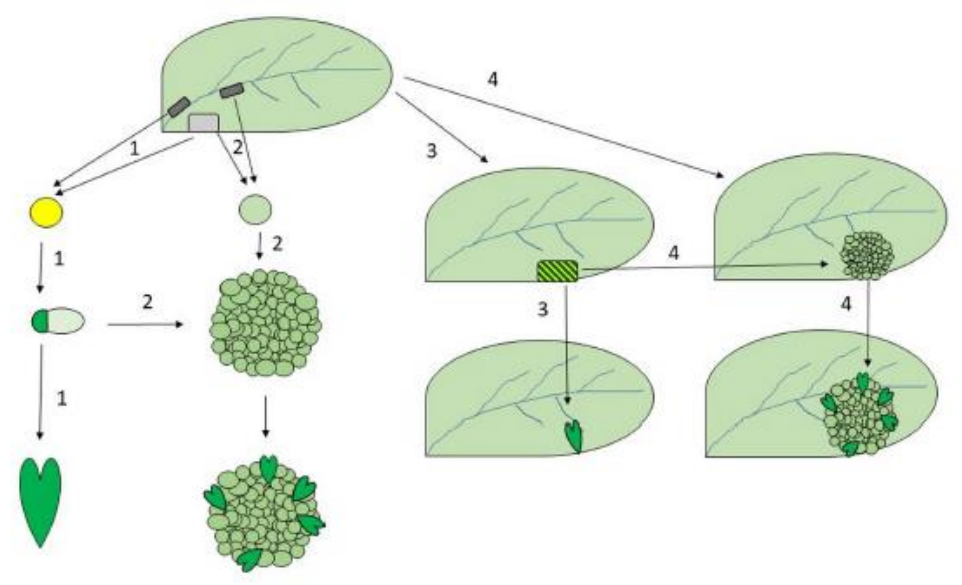

\section{3. ábra: Szomatikus embriók kialakulásának lehetséges útvonalai (Fehér, 2019 alapján).}

A szomatikus embriók fejlödése indulhat differenciált testi sejtekböl (világosszürke) vagy periciklusszerü össejtekböl (sötétszürke) és végbemehet a folyamat direkt $(1,3)$ vagy indirekt $(2,4)$ módon in vitro $(1,2)$, valamint in planta $(3,4)$. In vitro szomatikus embriógenezis (SE) indulhat egyetlen totipotens sejt (sárga) indukciójával, mely proembriót (sötétzöld) hoz létre az elsö aszimmetrikus osztódást követöen (közvetlen vagy direkt SE; 1). Szomatikus embriók alakulhatnak ki in vitro embriogén kallusz felszínén több sejtböl (közvetett vagy indirekt SE; 2). In planta SE is elindulhat direkt (3) vagy indirekt (4) módon bizonyos szabályzó gének mutációjának vagy ektópikus túltermelödésének eredményeként. Amennyiben ez a folyamat egyetlen embriogén sejtben indul (3), akkor ez a sejt is totipotensnek tekinthetö (sárga, sötétzöld vonalakkal), de expressziós mintázata valószinüleg különbözik a hipotetikus zigótaszerü totipotens sejtétöl (sárga, l-es folyamatnál). Figyelembe kell venni, hogy sem a differenciált szomatikus sejtek, sem a periciklusszerü össejtek önmagukban nem totipotensek és szomatikus embriók egyetlen totipotens sejt részvétele nélkül is kialakulhatnak (2-es folyamat), (a rajzok nem méretarányosak).

Nem minden növényi sejt totipotens, de egyes sejtek megfelelő körülmények alatt totipotenssé válhatnak. Egy sejt (és csakis egyetlen sejt) tekinthető totipotensnek, amennyiben képes önállóan embriógenezisen keresztül egész növénnyé fejlödni. A közvetett, több sejtből kiinduló SE nem függ a celluláris totipotenciától (3. ábra; Fehér, 2019). Az embriogén képesség vagy potenciál egy adott növényi genotípus, illetve explantum azon tulajdonságainak összessége, amely megfelelő belső és külső körülmények teljesülése esetén megengedi, hogy differenciált sejtekböl embriogén sejtek fejlödhessenek (Fehér, 2005). Ez a kompetencia azonban nem minden sejtre jellemző, azoknak csak bizonyos hányadában alakul ki. Általánosságban véve elmondható, hogy a differenciált sejtek speciális funkcióinak elvesztése az embriogén kompetencia kialakulásának feltétele. A folyamat során a sejt képes lesz olyan hormonális, illetve stressz tényezők szignálként való felfogására, amelyek az embriógenezis kiváltásához vezetnek. 
Az embriogénné válás képességét más tényezők, úgymint a kiindulási állapot (fejlődési állapot, explantum típus), stresszkezelések (sebzés, ozmotikus stressz, nehézfémstressz, hideg stressz vagy magas hőmérséklet), a kezelés időtartama, a külső környezet, a mesterséges táptalaj alkotó elemei, a megvilágítás, illetve az alkalmazott növekedésszabályozó anyagok (auxin, citokinin) is meghatározzák (Ikeda-Iwai és mtsai., 2003; Gaj, 2004; Fehér, 2015). A mechanizmus azonban, ami által egy sejt az embriógenezisre újra képessé válik csak részben feltárt és jelenleg is intenzív kutatások tárgyát képezi (Fehér és mtsai., 2003; Jiménez, 2005; Venglat és mtsai., 2005; Fehér, 2015).

Annak ellenére, hogy a különböző embriogén fejlődési utak során a fejlődési program meglehetősen hasonló és az embriók hasonló fejlődési fázisokon mennek keresztül (lásd 1. ábra), különbségeket is tapasztalhatunk. Az in vitro embriók gyakran nagyobbak, több sejtből állnak és kevésbé organizált a felszínük a zigotikus embriókhoz képest. Ez leginkább az anyai környezet és az endospermium hiányának köszönhető. A környező magszövetek hiányában az in vitro fejlődő embrió érése szintén eltér a zigotikus embrióétól, mivel az előbbi esetben például nem alakul ki dormancia, azaz nyugalmi állapot (Zimmerman, 1993; Fehér, 2015), továbbá a fejlődő embriónak nincs vaszkuláris kapcsolata azzal a szövettel, melyen kialakult (Solís-Ramos és mtsai., 2012). Ez utóbbi lényegi különbséget jelent az organogenezis során képződött merisztematikus struktúrákhoz képest, mely esetben ez a vaszkuláris kapcsolat fellelhető a regenerátum és a kiindulási szövet között (Terzi és Lo Schiavo, 1990).

\subsubsection{In vitro szomatikus embriógenezis gyakorlati alkalmazása}

A szomatikus, illetve mikrospóra-eredetü embriogén tenyészetek előnye, hogy bennük nagy számban fejlődhetnek az anyaszervezettől független, szabadon álló embriók, melyek jól használhatóak fejlődésbiológiai, biokémiai, élettani és molekuláris biológiai kutatásokban. Az in vitro környezetben fejlődő szomatikus embriók morfológiai, citológiai, biokémiai és génexpressziós vizsgálatával a ZE modellezhető, ezen felül összevethetők a különböző sejtekből kiinduló embriófejlődési rendszerek, ami által a növényi embriógenezisre, mint fejlődési programra vonatkozó általános következtetések vonhatók le (Touraev és mtsai., 1995; Kasha és mtsai., 2001; Fehér és mtsai., 2003; Sprunck és mtsai., 2005; Fehér, 2015). A növények fejlődési plaszticitásának jobb megértésére is eszközként szolgálhat a SE tanulmányozása.

A szomatikus embriók in vitro tenyésztése számos növény ivartalan szaporítására kínál megoldást, továbbá a növénynemesítésben is jelentős szerepe lehet. A SE lehetővé teszi a kiváló tulajdonságokkal bíró nemesítési alapanyagok, fajták, hibridek gyors vegetatív felszaporítását, 
fenntartását, mely során változatlanul megőrződik a hibridek, fajták, vonalak genetikai állománya, mert kiiktatódik az ivaros keresztezéssel összefüggő genetikai rekombináció. Erre alapozva kezdődtek el a “mesterséges magok” előállítását és felhasználását célzó kutatások (Rihan és mtsai., 2017). Az embriók in vitro előállítása tehát mind fejlődésbiológiai, mind gazdasági szempontból fontos (Dudits és Heszky, 2014).

\subsection{Organogenezis}

Az organogenezis egy teljes növényi szerv regenerációját jelenti, mely történhet in planta vagy megfelelö indukciós körülmények esetén in vitro. A de novo organogenezis egy általánosan használt növényi stratégia a túlélésre. A természetben de novo organogenezissel általában gyökerek és/vagy hajtások alakulnak ki, lehetővé téve a károsodott vagy eltávolított szervek pótlását. Szövettenyészetekben a leválasztott szövetek, szervek arra alkalmas tápközegben elöször általában hegszövetet, "kalluszt" alakítanak ki, melyböl gyökerek vagy hajtások fejlödhetnek. Ezt a fajta organogenezist nevezzük indirekt vagy közvetett organogenezisnek. Az organogén kallusz sebzés hatására testi sejtekből (Iwase és mtsai., 2011a; 2011b), illetve exogén auxin és citokinin kezelést követően a periciklus (gyökér) vagy periciklusszerü (hajtás) szövet merisztematikus sejtjeiből képződhet (Atta és mtsai., 2009; Xu és Huang, 2014). Közvetlen (kalluszképződés nélküli) hajtásregenerációt lehet elérni oldalgyökér kezdeményekböl citokininek magas koncentrációban történő alkalmazásával (Rosspopoff és mtsai., 2017). Az oldalgyökér iniciáció korai szakaszában a merisztematikus sejtek a citokinin:auxin aránytól függően hajtás- vagy gyökérmerisztémává is fejlödhetnek. A citokininek fontos szerepet játszanak az in vitro hajtás kialakulásban (Aragão és mtsai., 2016; Rosspopoff és mtsai., 2017). A hajtásregenerációhoz a magas citokinin szint mellett azonban egy megfelelő auxin grádiens is szükséges (Negin és mtsai., 2017).

Shin és munkatársai (2020) szerint a hajtás de novo organogenezisének négy fő lépése különböztethető meg: első lépés a "pluripotencia” megszerzése (Che és mtsai., 2007; Atta és mtsai., 2009; Kareem és mtsai., 2015; Liu és mtsai., 2018); második a hajtás promerisztéma kialakulása (Aida és mtsai., 1999; Ikeda és mtsai., 2006a; Gordon és mtsai., 2007; Pulianmackal és mtsai., 2014; Iwase és mtsai., 2017); harmadik a hajtás progenitor kialakulása (Che és mtsai., 2002; Cheng és mtsai., 2013; Zhang és mtsai., 2017), majd végső lépés a hajtás kiemelkedése (Sang és mtsai., 2018; Tian és mtsai., 2018; Lee és mtsai., 2019) (4. ábra). 


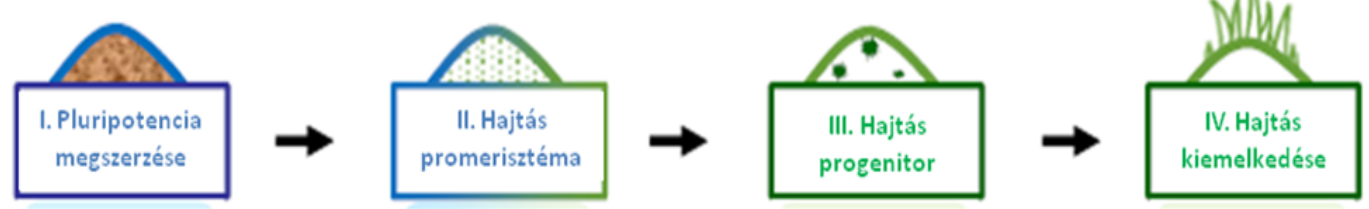

4. ábra: De novo hajtás organogenezis fő fázisai (Shin és mtsai., 2020 alapján).

Az ábrán a kék háttér az auxinban gazdag kallusz indukciós médiumot jelöli, míg a zöld háttér a citokininben gazdag hajtás indukciós tápközeget mutatja.

\subsection{A növényi hormonok szerepe a regenerációs folyamatokban}

A növényi regenerációs folyamatok indukálhatók különböző hormonok vagy stresszkezelések segítségével, a fajtól és/vagy az explantum típusától függően. A hormonok közül a két legjelentősebb az auxin és a citokinin, melyek direkt módon vesznek részt a regenerálásban, de egyéb növényi hormonok is szerepet játszanak ezekben afolyamatokban (Su és Zhang, 2014). A regeneráció sikerét az endogén hormonok megfelelő térbeli eloszlása és megfelelő időben történő alkalmazása befolyásolja (Jiménez, 2005; Su és Zhang, 2014).

\subsubsection{Az auxinok szerepe}

$\mathrm{Az}$ in vitro regenerációs eljárásokban a hormonok közül a legjelentősebb az auxinok szerepe, ezen belül is a leggyakrabban használt a 2,4-diklórfenoxi-ecetsav (2,4-D) (49\%-os gyakorisággal használt), ezt követi a naftilecetsav (NES) (27\%), az indol-3-ecetsav (IES) (6\%), majd az indol-3-vajsav (6\%), a pikloram (5\%) és a dikamba (5\%) (Jiménez, 2001). A 2,4-D egyik sajátossága, hogy növényi növekedésszabályzó és stressz indukáló ágens is egyben és ezen ellentmondásos tulajdonságának köszönheti embriógenezis indukáló képességét. Ezt bizonyítja, hogy Arabidopsis SE kezdeti szakaszában a 2,4-D által indukált transzkripciós faktorok (TF-ok) közel fele stresszhez kapcsolt (Gliwicka és mtsai., 2013). 2,4-D kezelés hatására megemelkedik az endogén auxin szint a kompetens sejtekben (Michalczuk és mtsai., 1992; Pasternak és mtsai., 2002). A belső hormonszinteket vizsgálva több faj, illetve explantum esetében megfigyelték, hogy a 
magasabb endogén auxin szint magasabb szintű embriogén válasszal jár együtt (Ivanova és mtsai., 1994; Jiménez és Bangerth, 2001a; 2001b; 2001c; Jiménez és Thomas, 2006). Azonban az exogén auxint a tápközegből el kell távolítani ahhoz, hogy a sejt és/vagy szövet polaritása kialakulhasson és a SE meginduljon (Raghavan, 2004; Jiménez, 2005). A 2,4-D eltávolítása indukálja az auxin bioszintézisért felelős flavin monooxigenázokat kódoló YUCCA (YUC) gének expresszióját lúdfüben - ennek eredménye a megnövekedett endogén IES szint (Bai és mtsai., 2013). A merisztéma (őssejt populáció) kialakulásában fontos szerepe van a lokális auxin bioszintézisnek és a poláris auxin transzportnak (Nawy és mtsai., 2008). Bai és munkatársai (2013) kimutatták, hogy a 2,4-D indukálta SE kezdetén Arabidopsis kalluszban számos citokinin, abszcizinsav (ABS), továbbá etilén szintézisben és jelátvitelben résztvevő gén alulmüködött, míg ezzel párhuzamosan megnőtt az endogén auxin szintézisért felelős $Y U C$ gén expressziója. Arabidopsis regenerációjának korai fázisában az auxin aszimmetrikus eloszlása - melynek kialakításában fontos a poláris auxin transzport - jelentős szerepet tölt be (Su és mtsai., 2009; 2015). Ezen túlmenően az auxin poláris transzportja szükséges az apikális-bazális embriogén tengely és később a bilaterális szimmetria kialakításához az embriógenezis során (Woodward és Bartel, 2005). Mindezek alapján az auxin transzport gátlása megzavarhatja az auxin időbeli/térbeli eloszlását és megakadályozhatja a hajtásregenerációt (Cheng és mtsai., 2013), valamint a SE-t (Elhiti és Stasolla, 2011). Az auxin poláris transzportjának a növény fejlődésében betöltött szerepét a transzport gátlásával vizsgálhatjuk. Ilyen gátlószerek például a 2,3,5-trijód-benzoesav (TIBA), valamint a naftilftálsav (NPA). A TIBA-t először a fotoperiódus virágzási időre gyakorolt hatásainak vizsgálatára használták (Zimmerman és Hitchcock, 1942) és gyorsan kiderült a kutatók számára, hogy a TIBA kompetitív módon gátolja az IES hatását szójababban (Galston, 1947). Mivel a TIBA egy gyenge aromás sav, úgy gondolják, hogy a protonált TIBA az IES-hez hasonló módon diffundál a sejtekbe, bár élettani körülmények között a sejtmembrán a TIBA tekintetében 100-szor nagyobb permeabilitással rendelkezik (Depta és mtsai., 1983). A NPA-tól eltérően a TIBA-ról úgy vélik, hogy az IES-hez hasonló módon polárisan szállítódik (Thomson és mtsai., 1973) közös efflux hordozókon keresztül (Depta és mtsai., 1983).

\subsubsection{A citokininek szerepe}

Növények regenerációjára leggyakrabban használt citokinin az $\mathrm{N}^{6}$-benzil-amino-purin (57\%), amit a kinetin (37\%), a zeatin (3\%) és a thidiazuron (3\%) követ (Jiménez, 2001). A citokinin a hajtás indukcióban feltételezhetően kulcs szerephez jut, úgymint az auxin a gyökér indukcióban (Skoog és Miller, 1957; Duclercq és mtsai., 2011). Pozitív korrelációt írtak le a citokinin szintek és 
a hajtás hónaljrügyek kialakulása között különböző mutánsokban és transzgénikus növényekben (Chaudhury és mtsai., 1993; Kakimoto, 2001; Catterou és mtsai., 2002; Sun és mtsai., 2003). Ugyanakkor azok az Arabidopsis mutáns növények, melyek auxin vagy citokinin szintézisben mutánsok, képtelenek a de novo hajtás organogenezisre (Hwang és Sheen, 2001; Inoue és mtsai., 2001; Sakai és mtsai., 2001; Che és mtsai., 2002; 2006; 2008; Pernisová és mtsai., 2009).

Több rendszerben az alacsony koncentrációjú citokinin auxinnal együtt alkalmazva embriógenezist indukál, ugyanakkor a citokinin kezelés gátló hatást is gyakorolhat az auxinindukált SE-re (Mujib és mtsai., 2016). Más esetekben a citokininek önmagukban is hatékonynak bizonyultak a SE indukciójában (Sagare és mtsai., 2000; Gaj, 2004; Chung és mtsai., 2005).

\subsubsection{Az etilén szerepe}

Az etilén kölcsönhathat az auxinnal a regenerációs folyamatokban (Su és Zhang, 2014). Az auxin többlet egyik legismertebb hatása kétsziküeknél az etilén túltermelődés (Song, 2013). Az etilén prekurzor 1-aminociklopropán-1-karbonsav (ACC) kezelés következtében kialakult túlzott mértékü etilén termelődés gátolja a regenerációt (Bai és mtsai., 2013). Arabidopsis szomatikus embriófejlődés indukciója során az etilén szintézis és jelátvitel folyamatosan alulszabályozott a 2,4D eltávolítását követően. Ugyanakkor úgy vélik, hogy az etilén termelődés 2,4-D hatására bekövetkező átmeneti növekedése szükséges a 2,4-D indukált SE-hez (Fehér, 2015). Az exogén etilén hatása a SE-re koncentráció és faj/genotípus függő (Zheng és mtsai., 2013a; 2013b). Kisebb koncentrációban (10-25 $\mu \mathrm{M}$ ACC) indukálhatja a szomatikus embriók kialakulását (Zheng és mtsai., 2013a; 2013b).

\subsubsection{Az abszcizinsav szerepe}

Az exogén ABS képes szomatikus embrió kialakulást indukálni bizonyos fajokban és explantumokban, például Arabidopsis hajtáscsúcsokban (Nishiwaki és mtsai., 2000; Kikuchi és mtsai., 2006) és valószínűleg fontos szerepet játszik az auxin-indukált SE iniciációjában (Su és mtsai., 2013; Fehér, 2015). A megfelelő auxin:citokinin arány mellett a gibberellinek szintjének csökkenése, valamint az ABS szintjének növekedése is szükséges ahhoz, hogy a testi sejtek sorsa megváltozzon és a sejtek embriógenezisre alkalmassá váljanak (Xu és Huang, 2014). Az ABS bioszintézis inhibítor fluridon-A kezelés hatására, valamint az ABS bioszintézis gén $A B A$ 
DEFICIENT 2 (ABA2) mutációjának eredményeként a szomatikus embrióképződés jelentős csökkenéséröl számoltak be (Su és mtsai., 2013).

\subsection{Transzkripciós faktorok szerepe az Arabidopsis in vitro regenerációjában}

Bár az in vitro regeneráció körülményeit számos növényfaj esetében kidolgozták és széles körben használják is a növények vegetatív szaporításában, a molekuláris mechanizmusokat részleteiben csak Arabidopsis thaliana modellnövény esetében ismerjük. Mivel magunk is ezt a növényfajt vizsgáltuk, a továbbiakban az Arabidopsis in vitro regenerációjában kísérletileg igazoltan szerepet játszó transzkripciós faktorokat tekintem át.

\subsubsection{A SE során szerepet játszó fóbb transzkripciós faktorok}

A legnyilvánvalóbb megközelítés a SE-ben részt vevő gének azonosítására a szomatikus embriók, a kallusz sejtek, valamint a csíranövények génkifejeződési mintázatának összehasonlítása (Zimmerman, 1993; Lin és mtsai., 1996; Dong és Dunstan, 1999). Ez a megközelítés azonban nem ad információt arról, hogy melyek azok a gének, amelyek az embriógenezis különböző fejlődési szakaszaiban specifikusan fejeződnek ki. Az embriófejlődés genetikai hátterének kutatásában a funkciómódosulást eredményező egyszeres és többszörös lúdfü mutánsok segítségével érték el ez idáig a legtöbb eredményt (Ikeda és mtsai., 2006b). Mindezek eredményeként az elmúlt években számos olyan gént sikerült azonosítani, melyek részt vesznek az embriógenezis szabályozásában. Néhány esetben azt tapasztalták, hogy ha az embriógenezis folyamatában aktiválódó TF-okat ektópikusan kifejeztetik vegetatív sejtekben, akkor azokban a sejtekben embriófejlődés indul el.

$\mathrm{Az}$ Arabidopsis éretlen zigotikus embriókban auxin által indukált direkt SE-t három magspecifikus TF expressziója jellemzi; a LEAFY COTYLEDON 1 és LEAFY COTYLEDON 2 (LEC1 és LEC2), valamint a FUSCA 3 (FUS3) (Gaj, 2001; Gaj és mtsai., 2005; Ledwoń és Gaj, 2011). A LEC1, LEC2 és FUS3 TF-ok egymással kölcsönhatásban szabályozzák a mag érése mellett a zigotikus embrió azonosságot (identitást) és ezzel összefüggésben az esetek egy részében a SE folyamatát is (Fehér, 2015; Fehér és mtsai., 2016). Azok a mutánsok, melyek nem képesek expresszálni ezeket a géneket, nem regenerálnak direkt embriógenezisen keresztül (Gaj és mtsai., 
2005), míg a LEC1-et és a LEC2-t ektópikusan expresszáló transzgénikus csíranövények szikleveleinek felszínén szomatikus embriók jelennek meg (Lotan és mtsai., 1998; Stone és mtsai., 2001).

\subsubsection{A LEC1 szerepe}

A LEC1 gén egy konzervált eukarióta transzkripciós faktor homológját kódolja, a CCAAT box-binding faktornak a HAP3 alegységével mutat hasonlóságot. Fontos szerepet tölt be mind a SE, mind pedig a ZE alatt (Ikeda-Iwai és mtsai., 2002; Zhang és mtsai., 2002; Yazawa és mtsai., 2003; Ikeda és mtsai., 2006b). A LEC1 magspecifikus TF, mely mind a korai, mind a kései embriófejlődés alatt aktív. A LEC1 szerepet játszik az embrió morfogenezisének szabályozásában és az embriogén szervek (pl. a sziklevelek) identitásának kialakításában is (Braybrook és Harada, 2008). A LECl gén nem expresszálódik posztembrionikusan, a vegetatív fejlődés elindulását (csírázás) lehetővé tevő kromatin módosulások hatására a kifejeződése megszünik (Rider és Henderson, 2003). SE során fontos szerepet játszik a szomatikus embriók differenciálódásában és fejlődésében (Gaj, 2011). Ektópikus expresszója embriószerű struktúrák megjelenéséhez vezethet transzgénikus növényekben (Lotan és mtsai., 1998), de ez a hatás fajspecifikus (Ledwoń és Gaj, 2011). Expresszióját az auxin fokozhatja (Gaj, 2011), míg a mag érése során az abszcizinsav regulált folyamatokban vesz részt (Braybrook és Harada, 2008). A lecl mutáns embriók nem kerülnek nyugalmi állapotba és intoleránsak a kiszáradásra (deszikkációra), valamint defektust szenvednek néhány - bár nem az összes - embrió érésével kapcsolatos gén expressziójában. A deszikkáció intoleráns lecl embriókat "megmenthetjük" kiszáradás előtt és in vitro környezetben kicsíráztathatjuk, hogy homozigóta mutáns növényeket kapjunk. A mutáns sziklevelein trichómákat, epidermális szőröket találhatunk, melyek normál esetben csak leveleken és szárakon alakulnak ki lúdfúben. A mutáns embriók tengelye rövid, a sziklevél kerek és a sziklevél csúcsánál antocianin halmozódik fel (Lotan és mtsai., 1998). A fontos különbségeket a vad típusú és a lecl mutáns embriók és csíranövények között az 5. ábra mutatja be. 


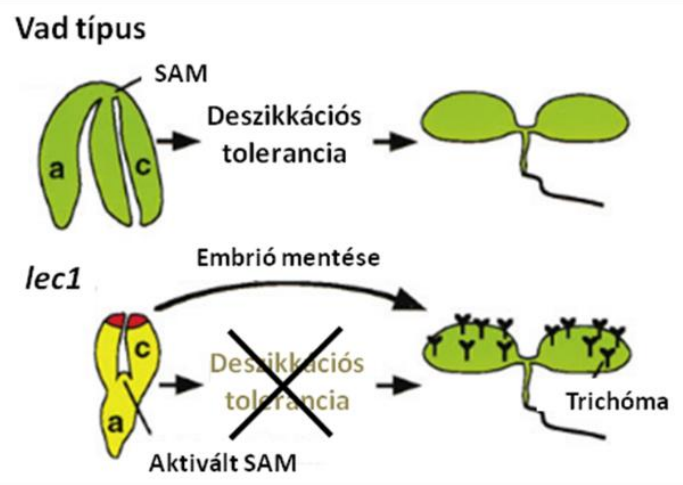

\section{5. ábra: A leafy cotyledon 1 (lec1) mutánsban a mutáció embriófejlődésre gyakorolt, több tulajdonság megváltoztatását eredményező hatása (Lotan és mtsai., 1998 alapján).}

\subsubsection{A LEC2 szerepe}

A B3 domént tartalmazó LEC2 TF ektópikus expressziója a LEC1-hez hasonlóan, szintén szomatikus embriószerü, valamint szervszerü struktúrák megjelenését eredményezi Arabidopsis csíranövények sziklevelein, levelein (Lotan és mtsai., 1998; Stone és mtsai., 2001). A gén kifejeződése becőspecifikus és auxin által közvetített (Santos-Mendoza és mtsai., 2005; Stone és mtsai., 2008). A LEC2 aktiválja a TRYPTOPHAN AMINOTRANSFERASE OF ARABIDOPSIS 1 (TAA1), valamint a YUCCA 2 és a YUCCA 4 (YUC2 és YUC4) gének expresszióját, amelyek az auxin bioszintézis útjában kulcsfontosságú enzimeket kódolnak (Zhao, 2014). A LEC2 által fokozott $Y U C$ génkifejeződés összefüggésben van annak embriógenezist indukáló képességével (Wójcikowska és mtsai., 2013). A LEC2 túltermelődése kompenzálhatja a 2,4-D szuboptimális mennyiségét vagy azon auxinokét, amelyek kevésbé hatékonyak a SE indukciójában, úgymint az IES vagy a NES (Wójcikowska és mtsai., 2013). Ezzel szemben a LEC2 ektópiás túlzott mértékü expressziója a normál 2,4-D koncentrációval kombinálva káros a SE indukciója szempontjából, mivel szomatikus embriók helyett kallusz képződik (Ledwoń és Gaj, 2009; Wójcikowska és mtsai., 2013). A lec1 mutáns növények mellett a lec2 mutánsokra is jellemző a trichómák megjelenése a szikleveleken (Stone és mtsai., 2001). 35S::LEC2-GR transzgénikus lúdfü gyökerekben a LEC2 aktiváció eredményeként embriogén kallusz alakult ki sebzés-függő módon (Iwase és mtsai., 2015). Braybrook és munkatársai (2006) kimutatták, hogy a 35S::LEC2-GR transzgén ektópiás expressziója aktiválja az INDOLE-3-ACETIC ACID INDUCIBLE 30 (IAA30) gén expresszióját. Mindezek alapján feltételezhető az auxin szignál és a LEC2 által indukált SE közötti potenciális kapcsolat. 


\subsubsection{A FUS3 szerepe}

A LEC2 TF-hoz hasonlóan B3 domént tartalmazó FUS3 TF-nak fontos szerepe van a vegetatív-embriogén átmenetben (Suzuki és McCarty, 2008). SE alatt a FUS3 expressziója auxin által stimulált (Kagaya és mtsai., 2005). Gaj (2011) ezzel szemben azt találta, hogy az auxin nem befolyásolja a FUS3 kifejeződését. Ily módon a lehetséges kapcsolat a FUS3 és az auxin között nem tisztázott teljes mértékben, további vizsgálatokat igényel. SE alatt a LEC1 és a FUS3 expressziós mintázata különböző volt, így valószínüsíthető a két gén eltérő feladata a SE folyamatában (Gaj, 2011). Habár a FUS3 expressziója nem köthető a SE egy bizonyos szakaszához, kifejeződése specifikus az embriogén kultúrában (Gaj, 2011). Funkcióvesztéses (loss-of-function) mutánsokkal igazolták, hogy FUS3 hiányában a hajtásregeneráció hatékonysága nő, az embriógenezisé pedig csökken (Gaj és mtsai., 2005). A FUS3 expressziós mintázata különböző ZE és SE alatt. ZE alatt a FUS3 expressziója a megtermékenyítést követő 2. héten indukálódik és kifejeződése a mag kiszáradásáig tart (Kroj és mtsai., 2003; Wang és mtsai., 2007). ZE-ben a LEC2 részt vesz a FUS3 szabályozásában, SE alatt azonban ez a kölcsönhatás nem figyelhető meg, ami alapján feltételezhető, hogy a LEC2 és a FUS3 gének közötti kölcsönhatás függ a sejt típusától (Gaj, 2011). ZE alatt a FUS3 expressziója LEC1 által is szabályozott, SE alatt auxin által stimulált (Kagaya és mtsai., 2005). Megfigyelték, hogy a LEC1 (Kagaya és mtsai., 2005), illetve a LEC2 (Stone és mtsai., 2008) a ZE különböző fázisai alatt indukálják és szabályozzák a FUS3 expresszióját. A FUS3 negatív szabályozó faktora a gibberellinsav (GS) akkumulációjának azáltal, hogy gátolja a GS bioszintézisben részt vevő géneket, valamint fokozza az ABS akkumulációját (Curaba és mtsai., 2004; Gazzarrini és mtsai., 2004). A többi LEC génhez hasonlóan, a FUS3 szintén részt vesz a magfejlődés érési szakaszának szabályozásában (Kagaya és mtsai., 2005).

\subsubsection{A WUSCHEL (WUS) szerepe}

A WUSCHEL homeotikus transzkripciós faktor határozza meg a hajtásmerisztéma identitását (Mayer és mtsai., 1998). Ennek megfelelően központi szerepet játszik a járulékos hajtás organogenezisében (Chatfield és mtsai., 2013). Negin és munkatársai (2017) kimutatták, hogy gyökérben a WUS aktiválódása elnyomja a sejtosztódást, a gyökér identitási gének expresszióját és gátolja az auxinra adott válaszokat, miközben az oldalgyökér primordiumok hajtásmerisztémává alakulnak.

A WUS gén kifejeződését leírták mind zigotikus, mind szomatikus embriókban. ZE alatt a 16-sejtes proembrióban (Mayer és mtsai., 1998), míg SE alatt az embriófejlődés korábbi 
szakaszában figyelték meg a gén auxin által indukált expresszióját (Su és mtsai., 2009). WUS túltermelő Arabidopsis mutánsokban ektópikus embriók jelennek meg a sziklevélen (Zuo és mtsai., 2002).

A WUS fontos szerepet tölt be a közvetett SE folyamatában. 2,4-D tartalmú táptalajon kialakult embriogén kalluszt auxinmentes médiumra helyezve endogén auxin szintézis indukálódik a kallusz szélső régiójában a YUC gének expressziójának köszönhetően (Bai és mtsai., 2013). Ezt követően a PIN-FORMED 1 (PIN1) auxin transzport fehérje szintézise indukálódik. A YUC és PIN1 szervezett elhelyezkedése auxin felhalmozódáshoz vezet a szélső sejtcsoportokban ( $\mathrm{Su}$ és mtsai., 2009). Közöttük, az auxin minimum helyén indul meg a hajtásmerisztéma azonosság szabályzó WUS gén kifejeződése (Su és mtsai., 2009). Ebben a korai fázisban a gyökérmerisztéma kialakulásának fó szabályzója, a WUS-RELATED HOMEOBOX 5 (WOX5) expressziója részben átfed a WUS expressziójával (Su és mtsai., 2015). Következő lépésben a sziklevél primordium az auxin maximumok helyein szerveződik a kallusz szélső régiójában. Ebben az időpontban citokinin felhalmozódás detektálható a WUS expressziós régió alatt, ahol ekkor a WOX5 kifejeződése is megfigyelhető. A citokinin termelés és a WOX5 expresszió a gyökérmerisztéma kialakulásának helyét jelzi. Ily módon a WUS és WOX5 kifejeződése elkülönül és kialakul az embrió apikálisbazális (hajtás-gyökér) tengelye, mielőtt a szomatikus embriók maguk láthatóak lennének (Su és mtsai., 2009; Bai és mtsai., 2013; Su és mtsai., 2015). A folyamatot a 6. ábra mutatja be sematikusan. 


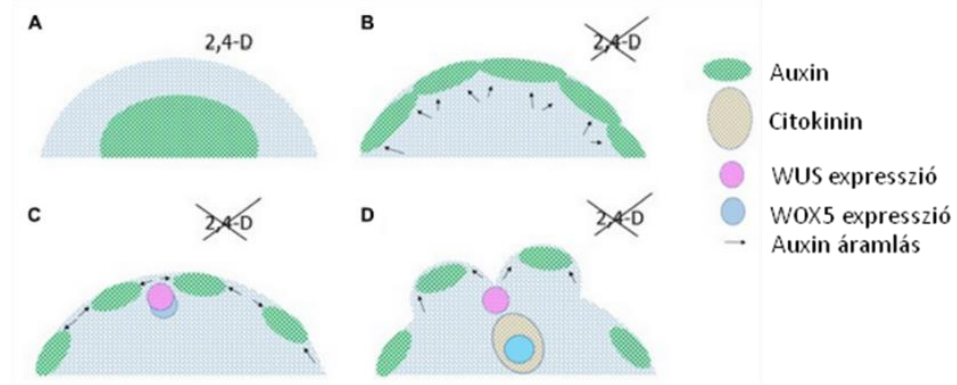

\section{6. ábra: Az embriogén kallusz felszínén a többsejtü szomatikus embriók kialakulása}

(az ábra forrása: Fehér, 2019).

A) 2,4-diklórfenoxi-ecetsav (2,4-D) jelenlétében kialakult embriogén kallusz fejlödése megáll, mig el nem távolítják az exogén mesterséges auxint. 2,4-D jelenlétében auxin a kallusz belsejében mutatható ki nagyobb mennyiségben. B) 2,4-D eltávolitása után endogén auxin termelödés indul meg. Az auxin a sejtek membránjában polárisan felhalmozódó PIN-FORMED 1 (PIN1) auxin efflux transzporterek által közvetített auxin transzportnak köszönhetöen a kallusz perifériája felé áramlik. C) PIN1 orientáció változása auxin felhalmozódást eredményez foltokban a kallusz felszínén. Ezen foltok között, az auxin minimumok helyén a WUSCHEL (WUS) transzkripciós faktor expresszálódik a WUS-RELATED HOMEOBOX 5 (WOX5)-tel részben átfedve. D) Sziklevél primordium kezd kialakulni az auxin maximumok helyén, míg közöttük a hajtásmerisztéma organizáló központja alakul ki azon sejtekböl, melyek expresszálják a WUS-t. A gyökérmerisztéma fejlödése a citokinin felhalmozódás és a WOX5 expresszió helyén indul. Su és mtsai., 2009; 2015, valamint Bai és mtsai., 2013 kísérletei alapján.

\subsubsection{A WOUND-INDUCED DEDIFFERENTIATION 1 (WIND1) szerepe}

A regenerációs folyamatok sebzés hatására is indukálódhatnak. A sebzés során az egyik elsőként aktiválódó TF az APETALA2/Ethylene Responsive Factor (AP2/ERF)-típusú WIND1 TF (Iwase és mtsai., 2011a; 2011b; 2015). Sebzés hiányában csíranövények gyökerén csak csökkent mértékü indirekt hajtás organogenezis figyelhető meg (Iwase és mtsai., 2015). A WIND1 ektópikus expressziójával megkerülhető a sebzés és az auxin szükségessége a de novo hajtás indukciójához gyökér explantumokon, jelezve, hogy a sebzés és az auxin hatását a WIND1 közvetíti (Iwase és mtsai., 2015). Ugyanakkor a WIND1 túltermelődés nem vezet emelkedett auxin akkumulációhoz, a sebzés helyén auxin válasz nem figyelhető meg, továbbá az auxin jelátviteli mutáns solitary root sebzés által indukált kallusz képződése normális (Iwase és mtsai., 2011a; 2011b; Ikeuchi és mtsai., 2017). Mindezek alapján feltételezhető, hogy az exogén auxin és a sebzés a kalluszképződést különböző útvonalakon aktiválja. A WIND1 ektópikus túltermelődése feltételezhetően citokinin 
jelátvitel-függő útvonalon (a citokinin válasz pozitív szabályzóin, a B-típusú Arabidopsis Response Regulator $(A R R)$ géneken keresztül) eredményezi kallusz kialakulását, majd a hajtásregenerációt (Iwase és mtsai., 2011a). A sebzés felülszabályozza a citokinin bioszintézist és jelátvitelt, mindezek a sejtosztódás aktiválódásához, majd kallusz képződéséhez vezetnek (Iwase és mtsai., 2011a; 2011b; Ikeuchi és mtsai., 2017). A WIND1 túltermelődése szomatikus embriók kialakulásához vezethet, ez alapján a sebzés indukálta kallusz bizonyos sejtjei embriogének (Iwase és mtsai., 2011a; Ikeuchi és mtsai., 2013).

\subsubsection{A de novo hajtás organogenezis során szerepet játszó főbb transzkripciós faktorok}

\subsubsection{A hajtásregeneráció közvetett és közvetlen útja}

$\mathrm{Az}$ Arabidopsis hajtásregenerációját elsősorban gyökér explantumokból kiindulva vizsgálták és mivel a mi kísérleti rendszerünk is gyökér alapú, az alábbiakban az ezzel kapcsolatos ismereteket tekintem át. Arabidopsis hajtások in vitro regenerációja gyökérből történhet közvetve, kallusz fázison keresztuil, illetve közvetlenül, oldalgyökér primordiumok átalakulásával.

A közvetett de novo hajtás organogenezis folyamatában a kallusz kialakulása a xilémpólusú periciklus sejtek auxin-indukált osztódásával kezdődik, ez a folyamat az oldalgyökér kialakulásához hasonló (Atta és mtsai., 2009; Sugimoto és mtsai., 2010). Számos TF, ami részt vesz az oldalgyökér kialakulásában, a kallusz kialakulásában is jelentős szerepet játszik. Ide tartozik az ABERRANT LATERAL ROOT FORMATION 4 (ALF4), mely fontos szerephez jut a periciklus sejtek kezdeti osztódásánál (Sugimoto és mtsai., 2010; Shang és mtsai., 2016). A gyökérmerisztéma kialakításában szerepet játszó gének expressziója, úgymint a WOX5, SCARECROW (SCR), PLETHORA 1 (PLT1), PLETHORA 2 (PLT2), ROOT CLAVATA-HOMOLOG 1 (RCH1) és a SHORTROOT (SHR) a kallusz kialakulása során is megjelenik, de kevésbé szervezett módon (Atta és mtsai., 2009; Sugimoto és mtsai., 2010). A regenerációs képesség kialakításában számos, a gyökér fejlődését szabályzó faktor játszik szerepet. Ilyen a hiszton-acetiltranszferáz fehérje HISTONE ACETYLTRANSFERASE OF THE GNAT/MYST SUPERFAMILY 1 (HAG1)/GENERAL CONTROL NON-REPRESSED 5 (GCN5), melynek feladata az őssejt populáció fenntartása a gyökérben azáltal, hogy szabályozza a PLT1 és a PLT2 gének expresszióját (Vlachonasios és mtsai., 2003; Kornet és Scheres, 2009; Servet és mtsai., 2010). A PLT1 és a PLT2 homeotikus transzkripciós faktorok elengedhetetlenek a gyökérmerisztémának és a gyökér fejlődési 
mintázatának kialakításában (Aida és mtsai., 2004; Guillotin és Birnbaum, 2020). Ennek során a gyökér auxin grádiense által szabályozott kifejeződésüknek köszönhetően dózis-függő módon szabályozzák a sejtek differenciáltsági állapotát a gyökér egyes régióiban, ami alapvetően meghatározza a régiók regenerációs képességét (Durgaprasad és mtsai., 2019). Kimutatták, hogy a gyökérből képződött kallusz szövet regenerációs képessége függ a PLETHORA 3, 5 és 7 (PLT3, PLT5, PLT7) faktoroktól is, melyek szintén transzkripcionálisan szabályozzák a PLT1, PLT2 géneket (Kareem és mtsai., 2015). Az oldalgyökér kialakulásának kezdetén a WUS-RELATED HOMEOBOX 11 (WOX11)-LATERAL ORGAN BOUNDARIES DOMAIN 16 (LBD16) szabályozó modul, mint a gyökérmerisztéma génexpressziójának upstream szabályozó komplexe, szintén meghatározza a kalluszképződés kezdeti lépéseit (Liu és mtsai., 2018). A hajtás promerisztéma kialakulása a kalluszban, a későbbiekben tárgyalt módon, citokinin alkalmazásával érhető el.

Az oldalgyökér primordiumból történő direkt hajtásregenerációhoz a még nem teljesen elkötelezett apikális gyökérmerisztéma őssejtek jelenléte szükséges, így ez a regenerációs útvonal az oldalgyökér fejlődés meghatározott szakaszaiban indítható el (VI. és VII. fázisok - Rosspopoff és mtsai., 2017). A kompetens oldalgyökér primordiumok a pluripotencia fenntartásában részt vevő merisztematikus géneket expresszálnak, úgymint a gyökérmerisztéma identitási faktor WOX5-öt, melynek kifejeződése megkönnyíti a sejtek átprogramozását, hogy a primordium később hajtássá alakuljon (Rosspopoff és mtsai., 2017). Rosspopoff és munkatársai (2017) kimutatták, hogy az oldalgyökér primordiumok fejlődésének programja a fenti fejlődési szakaszokban rendkívül plasztikus: ugyanazon sejtcsoport auxin hatására gyökérmerisztémává, citokinin hatására hajtásmerisztémává fejlődik és ezek a fejlődési utak többször is átkapcsolhatóak.

\subsubsection{A hajtás promerisztéma kialakulása}

A CUP-SHAPED COTYLEDON 1 (CUC1) és CUP-SHAPED COTYLEDON 2 (CUC2) fehérjék nélkülözhetetlenek a hajtás promerisztéma létrehozásánál (Aida és mtsai., 1999), kifejeződésük megelőzi más hajtásmerisztéma gének expresszióját a kalluszban és kijelölik a promerisztematikus régiókat (Gordon és mtsai., 2007; Pulianmackal és mtsai., 2014). A CUCindukált PIN1 auxin transzporter fehérje poláris lokalizációja meghatározza a hajtás progenitorok jövőbeli elhelyezkedését (Gordon és mtsai., 2007). Ezzel egyidőben a hajtásmerisztéma fenntartásáért felelős fő szabályzó, a SHOOT MERISTEMLESS (STM) expresszálódik a promerisztémában (Daimon és mtsai., 2003; Hibara és mtsai., 2003; Gordon és mtsai., 2007). A CUC1 és CUC2 túltermelődés növeli a kallusz regenerációs képességét (Daimon és mtsai., 2003). A 
CUC géneket számos upstream TF finomszabályozza, például az AP2/ERF-típusú ENHANCER OF SHOOT REGENERATION 1 (ESR1)/DORNRÖSCHEN (DRN) és ENHANCER OF SHOOT REGENERATION 2 (ESR2)/DRN-LIKE (DRNL) TF-ok. Arabidopsis-ban a regenerációs kompetencia megszerzését követően az ESRl transzkriptumok gyors felhalmozódása figyelhető meg kallusz indukciós médiumon és az ESR1 fehérje a $C U C 1$ lókuszhoz kötve aktiválja annak expresszióját. Ráadásul az ESR2, mely a későbbi szakaszban, a hajtás indukciós médiumon a hajtás regenerációjakor átmenetileg indukálódik (Ikeda és mtsai., 2006a; Matsuo és mtsai., 2011), direkt módon szabályozza a CYCLIN D1;1-et, az ARABIDOPSIS PHOSPHOTRANSMITTER 6-ot (AHP6) és a $C U C 1$-et (Ikeda és mtsai., 2006a). Az ESR2 a CUC1 expressziójának felülszabályzásával segíti a hajtás képződését (Xu és Huang, 2014). ESR1 és ESR2 túltermelődése de novo hajtásregenerációt indukál kalluszból (Banno és mtsai., 2001; Ikeda és mtsai., 2006a). Az ESR géneken kívül a PLT3, PLT5 és PLT7 gének is upstream szabályzói a CUC géneknek a de novo hajtás organogenezis alatt (Kareem és mtsai., 2015).

\subsubsection{A hajtás progenitorok kialakulása}

A hajtásprogenitorok promerisztémából, illetve gyökérprimordiumokból való kialakulása során fő szerephez jut a WUS, mely a hajtáscsúcsi merisztéma szövetének fenntartásáért felelös, azáltal, hogy megakadályozza a merisztémát szervező központi sejtcsoport differenciálódását (Mayer és mtsai., 1998; Zuo és mtsai., 2002). A WUS továbbá elnyomja a gyökér azonossági gének auxin indukált expresszióját, hogy segítse a hajtásregenerációt (Negin és mtsai., 2017). Ebböl adódóan a WUS-t expresszáló sejtek jelölik ki a hajtás progenitor régióját (Gordon és mtsai., 2007). A WUS, a leucin gazdag ismétlődéseket tartalmazó receptor kináz CLAVATA 1 (CLV1), a CLAVATA 2 (CLV2) receptorszerü, kináz aktivitással nem rendelkező fehérje és a CLAVATA 3 (CLV3) ligand egy jelátviteli komplexet alkotnak, mely a WUS kifejeződésének kontrollálásával az össejt populáció fenntartásáért felel (Schoof és mtsai., 2000). A wus mutáns defektusokat mutat a kalluszból történő de novo hajtás organogenezisben (Gordon és mtsai., 2007), míg a WUS túltermelődés fertilis hajtások ektópikus megjelenését eredményezi, akár gyökércsúcsból is (Gallois és mtsai., 2004; Rashid és mtsai., 2007). A WUS-t, illetve a CUC2-t expresszáló sejtek megfelelő térbeli szerveződése lényeges a hajtás progenitor kialakulása során; ekkor a CUC2-t expresszáló sejteket WUS-t expresszáló sejtek veszik körül. A hajtás össejtek osztódása az újonnan kialakuló hajtás promerisztémájának radiális mintázatához vezet, amit többek között a $S T M$ expresszió jelez a merisztéma középpontját övező régióban. Ebben a stádiumban a PIN1 auxin transzporter fehérje is megjelenik a hajtás promerisztéma felszínén és a kialakuló poláris auxin transzport is szükséges a 
hajtás apikális merisztémájának szerveződéséhez és müködéséhez (Gordon és mtsai., 2007). A hajtásmerisztéma kialakulásában és fenntartásában a citokinin hormon is fontos szerepet játszik. A citokinin jelátvitelben szerepet játszó B-típusú ARR-ekről, mint például az ARR1, ARR2, ARR10 és ARR12 transzkripcionális szabályzókról kimutatták, hogy direkt módon kötnek a WUS gén promóteréhez és aktiválják annak expresszióját hajtás indukciós médiumon (Zhang és mtsai., 2017), továbbá erősítik a WUS expressziót azáltal is, hogy elnyomják a YUC-közvetítette auxin felhalmozódást (Meng és mtsai., 2017). A B-típusú ARR-ek fenntartják a jelátviteli homeosztázist azáltal, hogy direkt módon szabályozzák a hajtásregenerációt gátló A-típusú ARR-eket, melyek a citokinin jelátvitel negatív regulátorai (Mason és mtsai., 2005). A WUS is represszálja az A-típusú ARR5, ARR6, ARR7 és ARR15 gének expresszióját, tovább erősítve a negatív visszacsatoláson alapuló szabályozást (Leibfried és mtsai., 2005).

\subsubsection{A hajtás kialakulása}

A hajtás megjelenése és fejlődése az utolsó lépés a regeneráció során. A hajtás organogenezis késői szakaszában jelennek meg a hajtás és a levelek szerveződéséért felelős homeotikus transzkripciós faktorok (szervazonossági gének). Legjellegzetesebbek ezek közül a HDZIP III géncsalád tagjai, úgymint a PHABULOSA (PHB), PHAVOLUTA (PHV), REVOLUTA (REV), KANADI (KAN) és ARABIDOPSIS THALIANA HOMEOBOX GENE 8 (ATHB8) (Jung és Park, 2007; Liu és mtsai., 2012; Zhang és Zhang, 2012), melyek a hajtás, illetve a levelek különböző (adaxiális/abaxiális) régióinak kialakításáért felelnek. 


\subsection{Arabidopsis thaliana, mint a regeneráció modellnövénye}

A káposztafélék (Brassicaceae) családjába tartozó kétszikü, kistermetű, egynyári virágos növény kisméretü genommal rendelkezik. Alacsony kromoszómaszáma $(\mathrm{n}=5)$ is hozzájárult ahhoz, hogy 2000-ben az Arabidopsis lett az első növény, aminek a teljes genetikai állományát megszekvenálták. A teljes genom szekvenciája elérhető a The Arabidopsis Information Resource (TAIR) weboldalon. Kutatási célokra többféle ökotípust használnak. Vad, vagy másnéven standard típusnak a Columbia (Col) és a Landsberg erecta (Ler) vonalakat tekintik. A lúdfü gyors növekedése, valamint kis mérete miatt könnyen nevelhető fitotronban és steril körülmények között, Petri-csészében, mesterséges táptalajon is. A kis növényméret, a rövid életciklus és a kisméretű genom mind előnyt jelentenek a genetikai kutatásokban. Ezt a fajt széles körben alkalmazzák a kutatók fejlődésbiológiai és növénybiológiai modellnövényként, azonban a SE vizsgálatában ez ideáig korlátozott volt a lehetőség, mivel nem állt rendelkezésre egy olyan igazán hatékony kísérleti rendszer, ami ezt lehetővé tette volna. Ugyanakkor a gyökérből történő indirekt hajtásregeneráció rutin eljárásnak számít Arabidopsis esetében (Feldmann és Marks, 1986; Valvekens és mtsai., 1988).

\subsubsection{Arabidopsis növényregenerálás SE-n keresztül}

A növények regenerációja szempontjából azok a rendszerek, melyek a SE-t veszik alapul, sokkal hatékonyabbnak bizonyultak, mint azok, amelyek kallusz tenyészetből kiinduló indirekt organogenezisen alapulnak, mivel az előbbi esetekben csökken a szomaklonális variabilitás kialakulásának esélye. Az 1990-es évek óta több olyan rendszert dolgoztak ki, melyek megoldást kínálhatnak a SE lúdfüben való tanulmányozásához.

Huang és Yeoman (1983) érett magból indított kallusz tenyészet esetében figyeltek meg szomatikus embrióképződést Arabidopsis-ban.

Sangwan és munkatársai (1992), valamint Wu és munkatársai (1992) éretlen zigotikus embriókból indított tenyészetben is figyeltek meg SE-t. A rendszer azonban nem bizonyult hatékonynak. Az éretlen zigotikus embriókból indított tenyészetben azt tapasztalták, hogy a rendszer nem tartható fent hosszú távon, ami miatt nem alkalmas a szomatikus embriók biokémiai, illetve molekuláris biológiai vizsgálatára (Pillon és mtsai., 1996). A folyadékkultúrában való 
tenyésztés növelte a burjánzási rátát, valamint a sárga színű embriogén sejtek és szomatikus embriók számát (Ikeda-Iwai és mtsai., 2002). Az embriogén kompetencia azonban ebben az esetben is rövid időn belül lecsökkent és szomatikus embriók helyett járulékos gyökerek képződtek. A rendszer hatékonysága növelhető volt, ha ezeket a csökkent embriogén kompetenciával rendelkező sejteket szilárd táptalajon, fényen tartották. Ebben az esetben zöld színű másodlagos szomatikus embriók alakultak ki. Ezek a másodlagos embriók azokkal az elsődleges embriókkal mutattak hasonlóságot, melyek éretlen zigotikus embriókból képződtek. A sejtek vissza tudták nyerni embriogén potenciáljukat és megfelelő mennyiségü embriogén sejt volt fenntartható. Gaj (2001) szintén éretlen zigotikus embriókat használt explantumként SE indukálására azok felszínén, 2,4-D alkalmazásával. Ez a mai napig a legelterjedtebb kísérleti rendszer Arabidopsis-ban a SE tanulmányozására. Hátránya, hogy manuálisan izolált éretlen zigotikus embriókat igényel, amelyek száma korlátozott és izolálásuk rendkívül munka- és időigényes. Megfigyelték, hogy az embriógenezis hatékonyságát nagymértékben befolyásolja az explantum fejlődési állapota. Wu és munkatársai (1992), valamint Luo és Koop (1997) szerint a korai fázisban levő, míg Pillon és munkatársai (1996) és Gaj (2001) szerint a késői fejlődési stádiumban (késői kotiledon fázis) levő zigotikus embriók alkalmasak erre leginkább.

O’Neill és Mathias (1993), majd Luo és Koop (1997) is levél protoplasztokban indukáltak SE-t, azonban ezek az embriók megrekedtek a korai globuláris stádiumban.

Ikeda-Iwai és munkatársai (2003) explantumként Arabidopsis csíranövények hajtásának apikális merisztémáját használták, majd a SE-t különböző stresszorok (ozmotikumok, nehézfém, szárazság, hideg) alkalmazásával indukálták. A stresszkezelés önmagában azonban nem volt elegendő a SE indukciójához. A szomatikus embriók képződéséhez a stresszkezelés mellett szükség volt 2,4-D alkalmazására is. Szomatikus embriók abban az esetben képződtek, amikor az explantumot először olyan hormonmentes (HM), szilárd B5 táptalajon tenyésztették, mely táptalaj tartalmazta a stresszt kiváltó komponenseket, de fitohormont nem, majd olyan táptalajon, mely a stressz kiváltására alkalmas anyagokat már nem, de fitohormonként 2,4-D-t tartalmazott. Ebben a kísérleti rendszerben az előzőekhez hasonlóan az embriógenezis hatékonyságát nagymértékben befolyásolta az explantum fejlődési állapota.

Márton és Browse (1991) lúdfü gyökerekből tenyészeteket hoztak létre. A gyökerek IES kezelésének eredményeképpen járulékos gyökerek képződtek. Ezután a gyökereket magas auxin, majd magas citokinin tartalmú táptalajra helyezték, aminek eredményeképpen a gyökereken egy idő után csíranövények jelentek meg. Feltételezték, hogy a folyamat SE-n keresztül történik, azonban ennek bizonyítására akkor még nem álltak rendelkezésre korszerű molekuláris biológiai eszközök. 


\subsubsection{Arabidopsis növényregenerálás organogenezisen keresztül}

Annak a felfedezésnek köszönhetően, mely szerint a magas auxin - alacsony citokinin arány gyökérfejlődést, a magas citokinin - alacsony auxin arány pedig hajtásregenerációt indukál, növényfajok százain vált lehetővé in vitro organogenezis rendszerek létrehozása. Számos tanulmány használta ki az Arabidopsis gyökerek hajtáskialakító képességét, hogy felmérjék azoknak a mutáns vagy transzgénikus vonalaknak a regenerációs kapacitását, melyekben a hormonszintek vagy a hormon érzékenység megváltozott (Endrizzi és mtsai., 1996; Kakimoto, 1996; Ozawa és mtsai., 1998; Daimon és mtsai., 2003; Ikeda és mtsai., 2006a; Mähönen és mtsai., 2006; Andersen és mtsai., 2008). Arabidopsis explantumok hajtás organogenezisét általában kétlépéses (indirekt) úton érik el (Feldmann és Marks, 1986; Valvekens és mtsai., 1988): első lépésként kalluszképződést indukálnak kiegyenlített hatású auxin és citokinin mennyiségekkel (kallusz indukciós médium), majd ezt követően a hajtásmerisztéma kialakulásához szükséges magas citokinin - alacsony auxin arányt biztosítják a táptalajban (hajtás indukciós médium).

Atta és munkatársai (2009) kimutatták, hogy az indirekt módon regenerált hajtások a xilém pólusokkal szomszédos periciklus sejtekből származnak. Ráadásul a hajtásregeneráció az oldalgyökér merisztéma kialakulásához részben hasonlónak tünt. 2,4-D-ben gazdag kallusz indukciós táptalajon a xilém periciklus újraaktiválódása kinövéseket hozott létre, melyek nem valódi kalluszok voltak, hanem az oldalgyökér merisztémák jellemzőit mutató sejtburjánzások. Citokininben gazdag hajtás indukciós médiumra helyezés ezeknek a speciális kalluszoknak a hajtásmerisztémává alakulását eredményezte. Sokáig úgy gondolták, hogy a kallusz kialakulása elkerülhetetlen lépés a hajtás in vitro organogenezise során. Atta és munkatársai (2009) a xilém pólus periciklusból végbemenő hajtás direkt módon történő kialakulását azáltal érték el, hogy kihagyták a kallusz indukciós táptalajon történő előtenyésztést és a gyökereket közvetlenül magas citokinin tartalmú táptalajra helyezték. Ez azonban nem bizonyult hatékonynak. Az elmúlt években azonban sikerült a módszert tökéletesíteni és kimutatni, hogy ebben az esetben a hajtás regenerációja kallusz átmenet nélkül, oldalgyökér primordiumokon keresztül történik. Ez a módszer a kallusz tenyészetből kiinduló organogenezishez képest rövidebb idő alatt teszi lehetővé a hajtás primordiumok kialakulását és ily módon a növényregenerálást.

Chatfield és munkatársai (2013) munkájuk során Arabidopsis csíranövények rövid NES kezelésével elérték, hogy a növények gyökerének teljes hosszán oldalgyökér primordiumok képződtek. Az auxin indukciót követően a csíranövényeket citokinin tartalmú táptalajra helyezték, melynek eredményeképpen az oldalgyökér primordiumok nagy hatékonysággal hajtásmerisztémává alakultak. 
Kareem és munkatársai (2016) ugyanezt a kísérleti rendszert használva azt tapasztalták, hogy a kezdeti NES indukció fontos az oldalgyökér primordiumok kialakulása szempontjából. NES indukció nélkül, citokinin jelenlétében kisebb mértékü volt a vágott gyökereken az oldalgyökér primordiumok megjelenése, mint NES indukcióval teljes csíranövények esetében. Azonban, ha a NES indukciót 24 óránál hosszabb ideig alkalmazták, csökkent az oldalgyökér primordiumok citokinin érzékenysége. A citokinin koncentrációja szintén fontos az oldalgyökér primordiumok hajtássá alakulásában. Ezen felül a gyökér fejlődési állapota, illetve a külső környezeti hatások is befolyásolhatják ezen primordiumok hajtássá történő átalakulását. A regeneráció szempontjából leghatékonyabb oldalgyökér primordium fejlődési állapotot Rosspopoff és munkatársai (2017) azonosították, tovább növelve a módszer reprodukálhatóságát. 


\section{CÉLKITÜZÉSEK}

Napjainkban a növényi biotechnológia talán legnagyobb előnyét és lehetőségét - az állati és humán kutatásokkal szemben - a kifejlett növényi szervezet regenerálásának lehetősége jelenti tenyésztett szomatikus sejtekből/szövetekből. Annak ellenére, hogy a SE-t széles körben alkalmazzák in vitro növényi szaporításhoz, ennek a növény-specifikus tulajdonságnak a biológiai háttere nem teljes mértékben ismert. Az Arabidopsis kedvező tulajdonságainak kihasználására a SE vizsgálatában ez ideáig korlátozott volt a lehetőség, mivel nem állt rendelkezésre egy olyan hatékony sejt- illetve szövettenyésztési kísérleti rendszer, ami ezt lehetővé tette volna. Egy hatékony Arabidopsis SE rendszer - amely megújuló és szinte korlátlanul rendelkezésre álló gyökértenyészeteken alapul - a jelenleg elterjedt zigotikus embriók tenyésztésén alapuló rendszernél egyszerübb és megfelelő minőségü, mennyiségü kísérleti anyagot szolgáltathat mind nagy áteresztő képességü, mind egyedi sejt-szintü vizsgálatokhoz. Emellett lehetővé tenné a SE és a hajtás organogenezis folyamatának összehasonlítását ugyanazon explantum esetében.

Mindezek végett munkánk során célul tüztük ki, hogy:

- létrehozzunk egy hatékony, gyökér alapú in vitro regenerációs kísérleti rendszert, mely lehetővé teszi Arabidopsis thaliana modellnövényen az organogenezis és a SE indukcióját, valamint a két folyamat összehasonlítását.

- Ennek eléréséhez pedig célul tüztük ki, hogy:

○ adaptáljuk a Márton és Browse (1991) által leírt regenerációs protokollt;

○ jellemezzük a Col ökotípust a SE/organogenezis kompetencia és hatékonyság szempontjából;

○ nyomon követjük a sejt- (mikroszkópia) és molekula (RT-QPCR) szintü változásokat térben és időben a regenerációs folyamatok indukciós szakaszában.

Ezen túl meg kívántuk vizsgálni, hogy:

○ mi okozhatja az eltérést a teljes csíranövények gyökere, illetve a csíranövényekből származó gyökér explantumok regenerációs képessége között. 


\section{ANYAGOK ÉS MÓDSZEREK}

\subsection{A kísérleti növény bemutatása, in vitro szövettenyészetek}

\subsubsection{Arabidopsis thaliana nevelési körülményei}

Kísérleteinkhez Arabidopsis thaliana (L.) vad típusú (Heynh Columbia ökotípus, Col) és heterozigóta leafy cotyledon 1 (lec1) egyszeres mutáns (AT1G21970) vonalakat használtunk (Meinke és mtsai., 1994). A növények magjait a Nottingham Arabidopsis Stock Centre (NASC) bocsátotta rendelkezésünkre (Scholl és mtsai., 2000).

\subsubsection{Vad típusú növények nevelése, előkészítése}

A Col magokat első lépésben sterilizáltuk, amihez 70\%-os etanolt, majd 4\%-os hígított nátrium-hipoklorit oldatot (4.5\% aktív klorin tartalmú Domestos) használtunk. Ezután steril vízzel mostuk a magokat öt alkalommal 1-1 percig. A sterilizált magok csíráztatása 120×120×17 mm méretü, négyzet alakú müanyag Petri-csészékben (Greiner Bio-One, International GmbH, Kremsmuenster, Ausztria) történt, 1\% szacharózt (VWR International LLC, Radnor, Pennsylvania, Egyesült Államok), 1\% plant agart (Duchefa Biochemie B.V., Haarlem, Hollandia) tartalmazó B5 táptalajon (Gamborg B5 Medium Including Vitamins, Duchefa Biochemie) (pH=5.7) steril körülmények között. 90 magot helyeztünk minden csíráztató lemezre. $21{ }^{\circ} \mathrm{C}$ hőmérsékletü növénynevelő szobában, folyamatos megvilágítás mellett a lemezeket horizontálisan tartottuk 1 napig, majd függőleges helyzetben további 6 napig. A fényintenzitás $50 \mu \mathrm{mol} \mathrm{m} \mathrm{m}^{-2} \mathrm{~s}^{-1}$ volt, melyet Sylvania Luxline Plus (Feilo Sylvania Europe Limited, London, Egyesült Királyság) fénycsövek biztosítottak. 


\subsubsection{Mutáns növények nevelése, előkészítése}

A lecl homozigóta mutáns növények előállításához steril körülmények között becőkből éretlen embriókat preparáltunk, melyeket később 1\% szacharózt, $0.5 \%$ plant agart és felezett koncentrációjú, B5 vitaminokat tartalmazó Murashige \& Skoog (1/2MS) táptalajon (Murashige \& Skoog Medium Including B5 Vitamins, Duchefa Biochemie) (Murashige és Skoog, 1962) (pH=5.8) csíráztattuk. Szelekciót követően a lecl fenotípust mutató csíranövényeket a vad típusnál alkalmazott körülményekkel megegyezően neveltük.

\subsubsection{In vitro gyökér alapú regenerációs rendszer}

A rendszer előállításához Márton és Browse (1991), Wenck és Márton (1995), Chatfield és munkatársai (2013), valamint Kareem és munkatársai (2016) által leírt módszereket alkalmaztuk, kisebb módosításokkal. A kísérletek során az egy hetes csíranövényeket 24 órán át szilárd $2 \mathrm{ml} / 1$ vitamix, 3\% szacharóz, 0.8\% plant agar, $2.7 \mu \mathrm{M}$ naftilecetsav (NES) (Duchefa Biochemie) tartalmú, B5 vitaminok nélküli MS táptalajon (Murashige \& Skoog Medium Basal Salt Mixture, Duchefa) $(\mathrm{pH}=5.8)$ tartottuk négyzet alakú müanyag Petri-csészékben, függőleges helyzetben. A vitamix összetétele az alábbi volt: $555 \mathrm{mM}$ mio-inozitol (Duchefa Biochemie); $14.8 \mathrm{mM}$ tiamin- $\mathrm{HCl}$ (B1 vitamin) (Duchefa Biochemie); $2.4 \mathrm{mM}$ piridoxin- $\mathrm{HCl}$ (B6 vitamin) (SERVA Electrophoresis GmbH, Heidelberg, Németország); $4.1 \mathrm{mM}$ nikotinsav (B3 vitamin) (Reanal, Budapest, Magyarország); $13.3 \mathrm{mM}$ glicin (Molar Chemicals, Halásztelek, Magyarország); $0.2 \mathrm{mM}$ biotin (Reanal). A túlzott gyökérszőr növekedés elkerülése érdekében az indukciót 24 óra elteltével leállítottuk és a csíranövényeket hormonmentes (HM) táptalajra (MS Basal Salt Mixture, 2 ml/1 vitamix, 3\% szacharóz, $0.8 \%$ plant agar) ( $\mathrm{pH}=5.8)$ helyeztük 3 napra. A regenerációs folyamatok indukciójához a növények egy részénél a hajtást eltávolítottuk az epikotil-hipokotil találkozási pontjánál, majd a gyökér explantumokat (16 db/lemez) - illetve a későbbiekben kontrollként használt vágatlan teljes csíranövényeket (16 db/lemez) - elöször magas auxin tartalmú ARM I (Arabidopsis regeneration media I; Márton és Browse, 1991), majd 3 nap elteltével magas citokinin tartalmú ARM IIr táptalajra (Arabidopsis regeneration media IIr; Márton és Browse, 1991) helyeztük. Az ARM I táptalaj az alábbi komponenseket tartalmazta: MS Basal Salt Mixture, 2 ml/1 vitamix, 3\% szacharóz, 0.8\% plant agar, 17.1 $\mu \mathrm{M}$ indol-3-ecetsav (IES) (Duchefa Biochemie), 0.7

$\mu \mathrm{M}$ 2,4-D (Sigma-Aldrich, St. Louis, Missouri, Egyesült Államok), $2.7 \mu \mathrm{M}$ 6-benziladenin (BA) (Sigma-Aldrich), $\quad 1.5 \mu \mathrm{M} \quad \mathrm{N}^{6}$-(2-izopentenil)-adenin (2iP) (6-( $\gamma, \gamma$-Dimethylallylamino)purine) 
(Sigma-Aldrich) (pH=5.8), az ARM IIr táptalaj összetevői az alábbiak voltak: MS Basal Salt Mixture, $2 \mathrm{ml} / 1$ vitamix, 3\% szacharóz, 0.8\% plant agar, $1.1 \mu \mathrm{M}$ NES, $19.7 \mu \mathrm{M} 2 \mathrm{iP}$ (pH=5.8). 4 nap citokinin indukció után a teljes növények és a vágott gyökerek egy részét (8-8 db) HM lemezekre [MS Basal Salt Mixture, 2 ml/1 vitamix, 3\% szacharóz, 0.8\% plant agar (pH=5.8)] tettük át.

Teljes csíranövények esetén a hajtásból származó auxin transzportot $5 \mu \mathrm{M}$ koncentrációjú 2,3,5-trijód-benzoesav (TIBA) (Fluka Chemie GmbH, Buchs, Svájc) segítségével gátoltuk. A TIBA-t alacsony olvadáspontú agaróz (Sigma-Aldrich) cseppben a hajtás és a gyökér találkozási pontjára helyeztük az auxin indukcióval egyidőben.

Mintákat vettünk az ARM IIr táptalajon 1-4 napja levő gyökér explantumokból, 5 napja HM táptalajon és 9 napja ARM IIr táptalajon levő citokinin indukált TIBA kezelt, illetve kezeletlen teljes csíranövények gyökeréből, valamint a vágott gyökerekből. Kontrollnak a HM táptalajon 5 napja levő, kezeletlen teljes csíranövények gyökerét, abszolút kontrollnak a csíráztató táptalajon levő, egy hetes csíranövények gyökerét tekintettük. A kísérleteket 3 biológiai ismétlésben végeztük el, legalább 3 párhuzamossal. A fent említett kísérleti rendszert, a TIBA kezelést és a mintavételeket a 7. ábra mutatja be. 


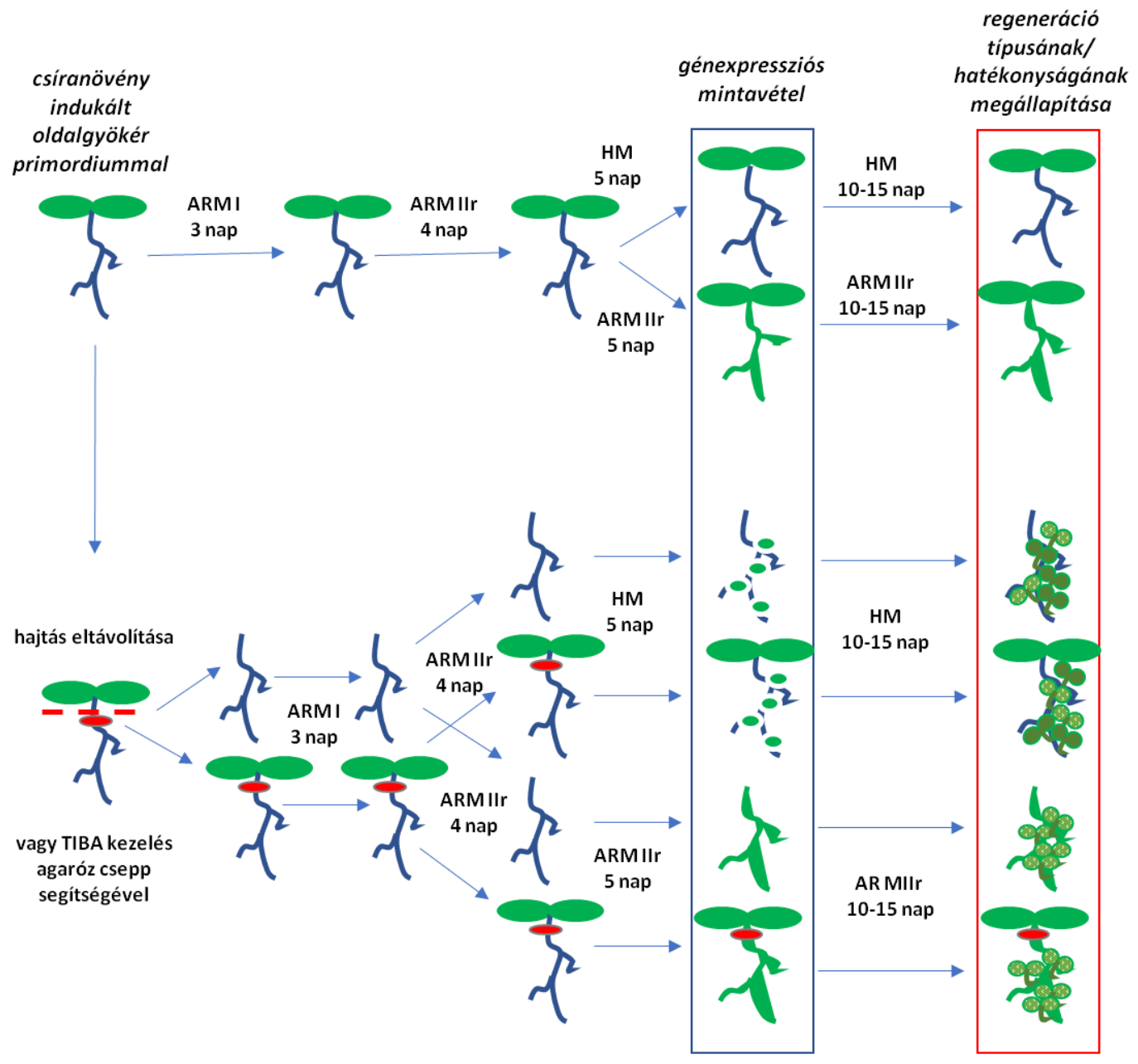

\section{7. ábra: Az in vitro gyökér alapú regenerációs rendszer sematikus ábrázolása.}

1 hetes Columbia (Col) ökotípusú csíranövények 1 napos, $2.7 \mu$ M naftilecetsav (NES) kezelése (oldalgyökér primordiumok indukciója), majd 3 napos hormonmentes (HM) lemezen történö tenyésztése után a csíranövények egy részét az epikotilhipokotil találkozási pontján 2,3,5-trijód-benzoesav (TIBA) tartalmú agaróz cseppel (piros ellipszis) kezeltük, másik részénél a gyökeret (kék vonal) a hajtásról (két zöld ellipszis) eltávolitottuk (piros szaggatott vonal) és késöbbiekben csupán a vágott gyökér explantumot használtuk. A kontrollként használt teljes növényeket nem kezeltük TIBA-val és a hajtást sem távolítottuk el. 3 napos auxin indukciót (Arabidopsis regeneration media I (ARM I) táptalaj), majd 4 napos citokinin indukciót (Arabidopsis regeneration media IIr (ARM IIr) táptalaj) követöen HM táptalajon az 5. napon (valós idejü kvantitativ polimeráz láncreakció (RT-QPCR) mintavételi idöpont, kék keret) a TIBA kezelés, illetve a hajtás eltávolitás eredményeként a gyökerek felszínén sötétzöld morfogén gócok jelentek meg (sötétzöld körök a kék keretben). 10-15 nap elteltével (sztereomikroszkópos vizsgálat, piros keret) ezen gócokból trichómákkal rendelkezö regenerátumok (világoszöld körök, fehér vonalakkal a piros keretben), valamint trichómákkal nem rendelkezö regenerátumok (sötétzöld körök a piros keretben) fejlödtek. Amennyiben a teljes növényeket folyamatosan magas citokinin tartalmú ARM IIr táptalajon tartottuk, 9 nap elteltével a növények gyökere vastagodott, kalluszosodott (vastagított zöld vonalak). 10-15 nap után a teljes növények gyökerén csupán trichómás regenerátumok jelentek meg. 


\subsection{Morfológiai vizsgálatok}

\subsubsection{Sztereomikroszkóppal végzett kísérletek}

A gyökér explantumokon, illetve a teljes növények gyökerén a sötétzöld morfogén gócok számát, valamint az első leveleken a trichómák jelenlétét/hiányát Olympus SZX12 sztereomikroszkóppal (Olympus Corporation, Sindzsuku, Tokió, Japán) vizsgáltuk fehér LED fényforrással (Photonic Optics, Bécs, Ausztria), hétszeres, tizenhatszoros, hússzoros nagyítások mellett. Fotók készítéséhez Olympus Camedia C7070 digitális kamerát használtunk (DScaler szoftver (4.1.15 verzió)).

\subsubsection{Pásztázó elektronmikroszkóppal végzett vizsgálatok}

Kísérleteinkhez JSM-7100F/LV pásztázó elektronmikroszkópot (JEOL Ltd., Akishima, Tokió, Japán) használtunk. Első lépésben a mintákat vákuum infiltráltuk és fixáltuk 100\%-os metanollal 20 percig, majd víztelenítettük 100\%-os etanollal 30 percig, friss $100 \%$-os etanollal egy éjszakán át. Másnap a mintákat a kritikus ponton kiszárítottuk, majd az elektronmikroszkóp mintatartóján rögzítettük. A bevonat nélküli leveleket és embriószerű struktúrákat visszaverődő elektronok detektálásával vizsgáltuk $15 \mathrm{kV}$ gyorsító feszültségnél és $35 \mathrm{~Pa}$ nyomásnál a mintakamrában.

\subsection{Molekuláris biológiai módszerek}

\subsubsection{RNS izolálás}

Az össz növényi RNS kivonáshoz a Quick-RNA ${ }^{\mathrm{TM}}$ Miniprep Kit-et (Zymo Research, Irvine, Kalifornia, Egyesült Államok) használtuk, a gyártó által javasolt protokoll szerint, mely egyben lehetővé teszi az RNS minták genomi DNS szennyezettségétől való megtisztítását. Az RNS mennyiségét a 260 nm-en mért optikai denzitás meghatározásával, NanoDrop ${ }^{\text {TM }}$ 2000/2000c spektrofotométeren ellenőriztük (Thermo Fisher Scientific, Waltham, Massachusetts, Egyesült 
Államok). A minták tisztaságára és minőségére az $\mathrm{OD}_{260} / \mathrm{OD}_{280}$ és az $\mathrm{OD}_{260} / \mathrm{OD}_{230}$ arányból következtettünk, illetve elektroforézissel (1\%-os agaróz gélben) ellenőriztük az esetleges degradációt.

\subsection{2 cDNS szintézis}

Az 500 ng - 1000 ng tisztított RNS mintákból a komplementer egyszálú DNS (cDNS) szintézisét a Precision nanoScript 2 RT kit (PrimerDesign Ltd., Chandler's Ford, Egyesült Királyság) reagenseinek alkalmazásával végeztük el, a gyártó utasítása szerint 20 percig $42{ }^{\circ} \mathrm{C}$-on, majd 10 percig $75{ }^{\circ} \mathrm{C}$-on $20 \mu \mathrm{l}$ végtérfogatban. Az átírt cDNS-eket kihígítottuk 1:10 arányban nukleázmentes AccuGENE ${ }^{\circledR}$ vízzel (Lonza, Verviers, Belgium). A cDNS minőségének ellenőrzését polimeráz láncreakció (PCR) technikával végeztük, kontrollként a GLYCERALDEHYDE-3PHOSPHATE DEHYDROGENASE gént (AtGAPDH; AT1G13440) használtuk. A PCR reakcióhoz Fermentas DreamTaq ${ }^{\mathrm{TM}}$ DNA Polymerase enzimet (Thermo Fisher Scientific) és Fermentas 10X DreamTaq ${ }^{\mathrm{TM}}$ puffert (Thermo Fisher Scientific) használtunk. A reakció 2 perces $95^{\circ} \mathrm{C}$-os hevítéssel kezdődött, majd 35 ciklus következett az alábbi paraméterekkel: $95{ }^{\circ} \mathrm{C} 30$ másodperc, $49{ }^{\circ} \mathrm{C} 30$ másodperc, végül $72{ }^{\circ} \mathrm{C} 30$ másodperc. A reakció 5 perces inkubációval zárult $72{ }^{\circ} \mathrm{C}$-on.

A használt primerek szekvenciái a következők voltak:

AtGAPDH_Fw:

5' ACTTGAagGGTGGTGCTAAA 3'

AtGAPDH_Rev:

5' ACATTCCGGTCAATTTTCCATT 3'

\subsubsection{Valós idejü kvantitatív polimeráz láncreakció (RT-QPCR)}

A génspecifikus primereket a Primer Express (Applied Biosystems, Foster City, Egyesült Államok) szoftver segítségével terveztük meg. A használt primerek listáját és szekvenciáját táblázatban foglaltuk össze (1. táblázat). A vizsgálni kívánt gének (CUC1 (AT3G15170), CUC2 (AT5G53950), ESR1 (AT1G12980), ESR2 (AT1G24590), LEC1 (AT1G21970), LEC2 (AT1G28300), FUS3 (AT3G26790), valamint a WIND1 (AT1G78080)) relatív expresszióját RT-QPCR segítségével, az Applied Biosystems cég ABI PRISM 7900HT Fast Real-Time szekvencia detektáló rendszerével (Thermo Fisher Scientific), valamint a qTOWER 2.0 (Analytic Jena AG, Life Science, Jéna, Németország) (14., 15. ábrákon szereplő eredmények) készülékekkel végeztük. Az adatok normalizálásához az AT2G41960 és UBIQUITIN 1 (UBQ1) háztartási géneket választottuk. A “The 
Bio-Analytic Resource for Plant Biology" (bar.u-toronto.ca; (Winter és mtsai., 2007) Arabidopsis Regeneration eFP browser alapján ez a két gén konstans módon expresszálódik az Arabidopsis gyökérből történő növényregenerációja során, illetve a növény egyéb szerveiben, szöveteiben. A valós idejü PCR során a DNS mennyiségének mérése fluoreszcens detektáláson alapul, amihez kísérleteink nagy részében kettős szálú DNS-hez kötődő fluoreszcens festéket, SYBR Green-t használtunk. A reakcióelegy végtérfogata $14 \mu \mathrm{l}$ volt, melyben $6 \mu$ lígított cDNS, $7 \mu 1$ PrecisionPLUS MasterMix with ROX premixed with SYBRGreen (PrimerDesign Ltd.), $0.5 \mu 1$ "forward" primer, $0.5 \mu \mathrm{l}$ "reverse" primer volt (az egyes oligonukleotidok $0.35 \mu \mathrm{M}$ végkoncentrációban voltak jelen). A reakció 10 perces $95{ }^{\circ} \mathrm{C}$-os hevítéssel kezdődött, majd 40 ciklus következett az alábbi paraméterekkel: $95{ }^{\circ} \mathrm{C} 15$ másodperc, $60{ }^{\circ} \mathrm{C} 1$ perc. A RT-QPCR lefutását követően a termék specifikusságát olvadási görbe detektálásával ellenőriztük az alábbi paraméterek segítségével: $95{ }^{\circ} \mathrm{C} 15$ másodperc, $60{ }^{\circ} \mathrm{C} 15$ másodperc, $95{ }^{\circ} \mathrm{C} 15$ másodperc.

Három technikai ismétlést végeztünk templátonként és primerenként, valamint ún. "non template control"-t (NTC) is alkalmaztunk kontrollként. Az adatok kiértékelését az SDS 2.3 szoftver (Life Technologies, Carlsbad, Kalifornia, Egyesült Államok) segítségével végeztük. A $\mathrm{C}_{\mathrm{T}}$ értékeket az RQ Manager 1.2 szoftver verzióval (Life Technologies) analizáltuk, majd Microsoft Excel 2010-be transzportáltuk. Az mRNS relatív transzkript szintjét az AT2G41960 és az UBQ1 (14., 15. ábrák) génekhez viszonyítva kalkuláltuk a (2) ${ }^{-\Delta \Delta C t}$ módszer segítségével.

\subsubsection{Statisztikai kiértékelés}

Az adatok statisztikai feldolgozásához és kiértékeléséhez a SigmaPlot v.12.0 (Systat Software Inc, San Jose, Kalifornia, Egyesült Államok) szoftver programját használtuk fel. A feltüntetett adatok minden esetben három független biológiai ismétlés átlag- és szórásértékei. A kontrolltól való szignifikáns különbségeket a varianciaanalízist (egyszempontos Analysis of variance (ANOVA)) követően a Duncan-féle teszttel (Duncan's new multiple range test (MRT)) állapítottuk meg. Az azonos betủvel nem jelölt átlagok szignifikánsan különböznek egymástól $\mathrm{P} \leq 0.05$ szinten. 


\begin{tabular}{|l|l|}
\hline Primer szekvenciák & Gén neve/AGI kód \\
\hline F: 5' -TTCTCTTGTGCCGCCATTTC - 3' & AtCUC1 (AT3G15170) \\
R: 5' -GCTTCTGTTGCTCTGTTCGT - 3' & AtCUC2 (AT5G53950) \\
\hline F: 5' - CTCCTTCCTCCGTCTCACTC - 3' & \\
\hline $\begin{array}{l}\text { F: 5' - GGGACAGTGGAGAAACAGGA - 3' } \\
\text { R: 5' - AACGATAAACCACCGTCTGC - 3' }\end{array}$ & AtESRl (AT1G12980) \\
\hline $\begin{array}{l}\text { F: 5' - GCTGACTTCCATGTCGAAGGA - 3' } \\
\text { R: 5' - TCTGCTGCATCTTAGCTGAATC - 3' }\end{array}$ & AtESR2 (AT1G24590) \\
\hline $\begin{array}{l}\text { F: 5' - GTTATGGTATGTTGGACCAATCC - 3' } \\
\text { R: 5' - TTCATCTTGACCCGACGAC - 3' }\end{array}$ & AtLEC1 (AT1G21970) \\
\hline $\begin{array}{l}\text { F: 5' - CGCCATGAATGGAAATTCGG - 3' } \\
\text { R: 5' - CCACGTACGCGTGATCCTGA - 3' }\end{array}$ & AtLEC2 (AT1G28300) \\
\hline $\begin{array}{l}\text { F: 5' - TGATACTCCCGAAGAAAGCC - 3' } \\
\text { R: 5' - CTATACTTGAAGGTCCAAACGTG - 3' }\end{array}$ & \\
\hline F: 5' - TGGCGGAGACTCAGAAACAG - 3' \\
R: 5' - GGCGACGAAACCTTCTTCTCA - 3' & AtFUS3 (AT3G26790) \\
\hline $\begin{array}{l}\text { F: 5' - TTCAATTAAAAGAGGGGAATGC - 3' } \\
\text { R: 5' - CTTTGTCTATCAGGACTTCATCCTC - 3' }\end{array}$ & \\
\hline $\begin{array}{l}\text { F: 5' - CGCAAGTGCTATGCTCGTCTT - 3' } \\
\text { R: 5' - GCCTCAACTGGTTGCTGTGA - 3' }\end{array}$ & \\
\hline
\end{tabular}

1. táblázat: A RT-QPCR során a transzkripciós szintek meghatározásához használt primerek jegyzéke. 


\section{EREDMÉNYEK}

\subsection{Arabidopsis in vitro gyökér alapú regenerációs rendszer}

\subsubsection{Kísérleti előzmények}

Arabidopsis gyökér alapú szövettenyészetekkel végzett munkák során korábban már megfigyelték a SE indukcióját, vagy legalábbis embriószerü struktúrák megjelenését (Márton és Browse, 1991; Mathur és mtsai., 1995; Wenck és Márton, 1995). Ebben a rendszerben az előzetesen folyadékkultúrában tenyésztett Col gyökerek felületén auxin indukciót (ARM I táptalaj) követően magas citokinin tartalmú (ARM IIr) táptalajon a gyökerek felületén embriószerü struktúrák képződtek. A rendszer adaptálása során azonban ettől eltérő reakciót tapasztaltunk: az auxin indukciót követően ARM IIr táptalajra helyezett gyökereken embrióképződés helyett kezdetben intenzív gyökérfejlődés, majd zöld kallusz megjelenése volt megfigyelhető (8. ábra).

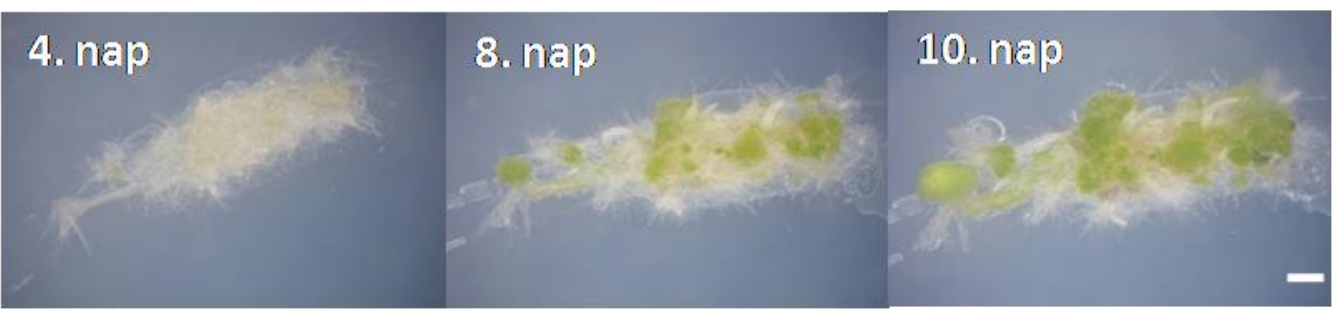

8. ábra: Columbia (Col) gyökér explantumok válasza Arabidopsis regeneration media IIr (ARM IIr) táptalajon Márton és Browse (1991) alapján.

Col gyökér explantumok sztereomikroszkópos képei ARM IIr táptalajon a 4., 8., 10. napokon (mérce: $1 \mathrm{~mm}$ ).

További 1 hét elteltével az explantumok felületén regenerátumok jelentek meg, melyek trichómával rendelkeztek (9. ábra). Miután az organogenezis, illetve a SE morfológiai markereként gyakran használatos az első levélszerü struktúrákon a trichómák meglétének (valódi levél, hajtás organogenezis), illetve hiányának (kotiledon, SE) vizsgálata (pl. Horstman és mtsai., 2017), feltételeztük, hogy a képződött regenerátumok indirekt hajtás organogenezisből származtak. 


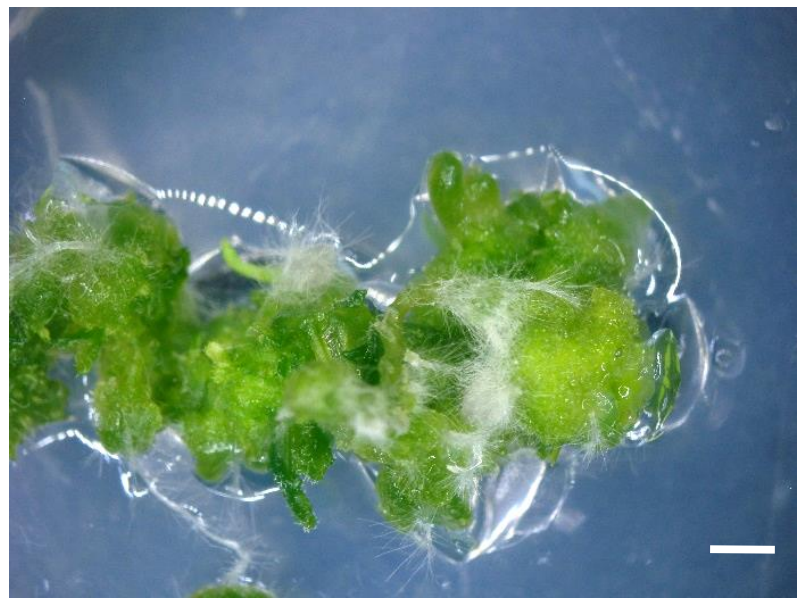

9. ábra: Col gyökér explantum válasza ARM IIr táptalajon Márton és Browse (1991) regenerációs protokollját alkalmazva.

Col gyökér explantum sztereomikroszkópos képe ARM IIr táptalajon a 18. napon (mérce: 1 mm).

\subsubsection{A rendszer optimalizálása}

Kezdetben folyadékkultúrát használtunk a gyökértenyészetek létrehozására, azonban miután folyadékkultúrában a gyökerek kora eltérő és ez a rendszer hatékonyságát, kiszámíthatóságát is negatív módon befolyásolta, továbbá mivel ezekben a kultúrákban fokozottan fennáll a különböző fertőzések kialakulásának esélye, a továbbiakban szilárd táptalajok használatára tértünk át. Az alkalmazott rendszer bemutatását a 4.1.2 fejezet tartalmazza.

\subsubsection{A citokinin megfelelő időben történő eltávolítása két regenerációs útvonal megjelenését indukálja}

\subsubsection{Sztereomikroszkóppal végzett morfológiai vizsgálatok}

Miután egyes esetekben az exogén auxint a tápközegből el kell távolítani ahhoz, hogy a SE meginduljon (Raghavan, 2004; Jiménez, 2005), megnéztük, hogy mi történik akkor, ha az auxin, majd citokinin indukciót követően a gyökér explantumokat hormonmentes tápközegre helyezzük. Azt is megvizsgáltuk, hogy van-e szerepe az időzítésnek, azaz annak, hogy mikor történik meg az explantumok átrakása citokinin tartalmú ARM IIr táptalajról HM táptalajra. Vizsgálataink alapján a 
leghatékonyabbnak a 4 napos citokinin indukció bizonyult (10. ábra, piros keret). A 4 napos citokinin indukció után HM lemezen a kalluszképződés korlátozódott és a gyökerek felületén zöld, globuláris struktúrák jelentek meg. További 6 nap elteltével ezek némelyike szomatikus embriószerü struktúrává fejlődött (10. ábra, fehér nyilak).

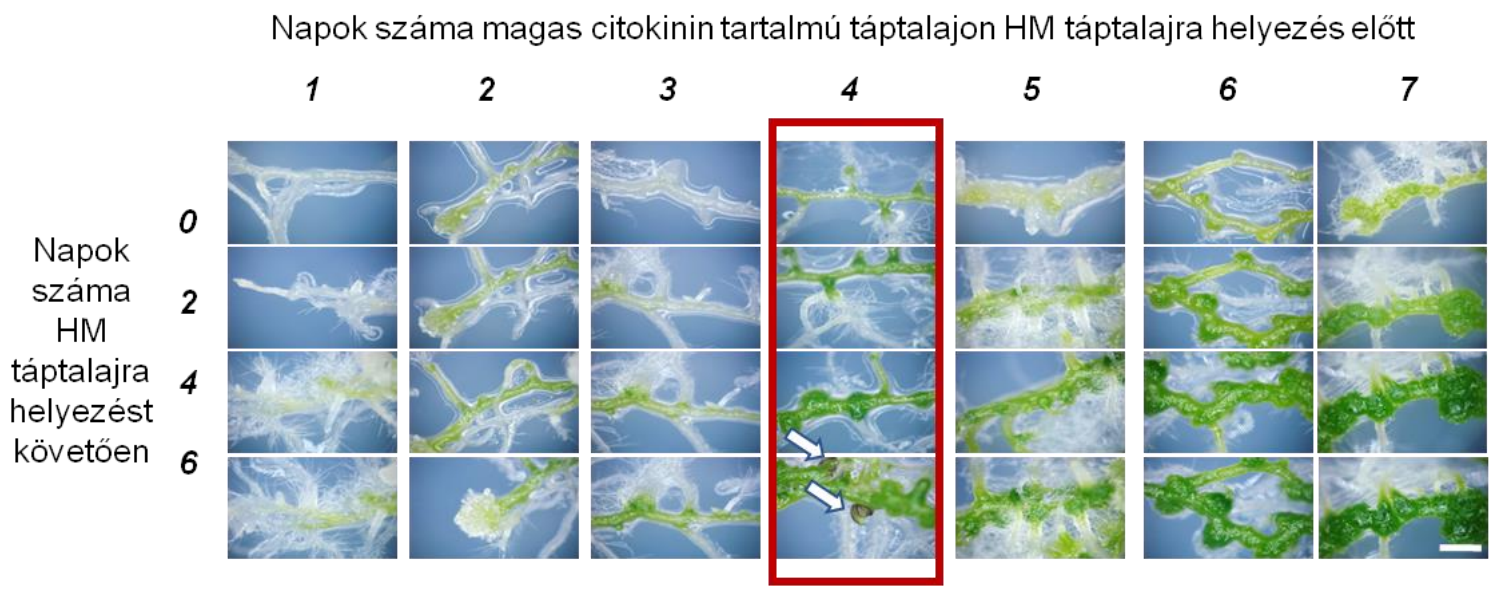

10. ábra: Előzetesen ARM IIr táptalajon 1-7 napig tenyésztett, majd hormonmentes (HM) lemezekre áthelyezett Col gyökér explantumok kalluszképződése és regenerációja.

A képek a HM lemezre helyezést követöen 0. napon, valamint 2, 4, 6 nap elteltével készültek. Fehér nyilak jelzik a regenerálódott szomatikus embriószerü struktúrákat, melyek 4 napig magas citokinin tartalmú médiumon (piros keret), majd 6 napig HM lemezen tenyésztett gyökér explantumokon jelentek meg (sztereomikroszkópos képek, mérce: $1 \mathrm{~mm}$ ).

További 2 hét elteltével a gyökér explantumok felületén regenerátumok alakultak ki (11. ábra C, D). A regenerálódott növények közel fele feltételezhetően embriogén eredetű volt, amit jelzett a trichómák hiánya a sziklevelek felszínén (11. ábra C, D; 12. ábra A; 2. táblázat). 


\begin{tabular}{|c|c|c|c|c|}
\hline Növényi anyag & $\begin{array}{c}\text { Regenerációs } \\
\text { gócok } \\
\text { száma/gyökér }\end{array}$ & $\begin{array}{c}\text { Regeneráció } \\
\text { gócokból } \\
(\%)^{\mathrm{b}}\end{array}$ & $\begin{array}{c}\text { Trichóma } \\
\text { nélküli } \\
\text { regenerátumok } \\
(\%)^{\mathrm{c}}\end{array}$ & $\begin{array}{c}\text { Trichómás } \\
\text { regenerátumok } \\
(\%)^{\mathrm{c}}\end{array}$ \\
\hline $\begin{array}{c}\text { Col gyökér } \\
\text { explantum }\end{array}$ & $\mathbf{8} \pm \mathbf{0 . 8}$ & $\mathbf{6 5 . 6 \pm 3 . 7}$ & $\mathbf{5 6 . 9 \pm 4 . 7}$ & $\mathbf{4 3 . 1 \pm 4 . 7}$ \\
\hline
\end{tabular}

\section{2. táblázat: Vad típusú Col gyökér explantumok regenerációs hatékonysága és típusa.}

${ }^{a}$ Zöld morfogén gócok gyökér explantumonként (hormonmentes lemezen 5. nap után számolva). Átlag standard hibája.

${ }^{b} A$ potenciális morfogén gócok azon százaléka, melyekböl teljes növény regenerálódott explantumonként. Átlag standard hibája.

'Azon regenerálódott növények százaléka, melyek valódi levelekkel/sziklevelekkel rendelkeztek trichómával/trichóma nélkül. Átlag standard hibája.

Ugyanebben a rendszerben, ha a gyökér explantumokat folyamatosan magas citokinin tartalmú ARM IIr táptalajon tartottuk, kezdetben intenzív kalluszképződés volt megfigyelhető (11. ábra E, F). További 2 hét elteltével trichómákkal rendelkező hajtások jelentek meg az explantumok felszínén (11. ábra G, H; 12. ábra B), utalva azok hajtás organogenezis eredetére. 

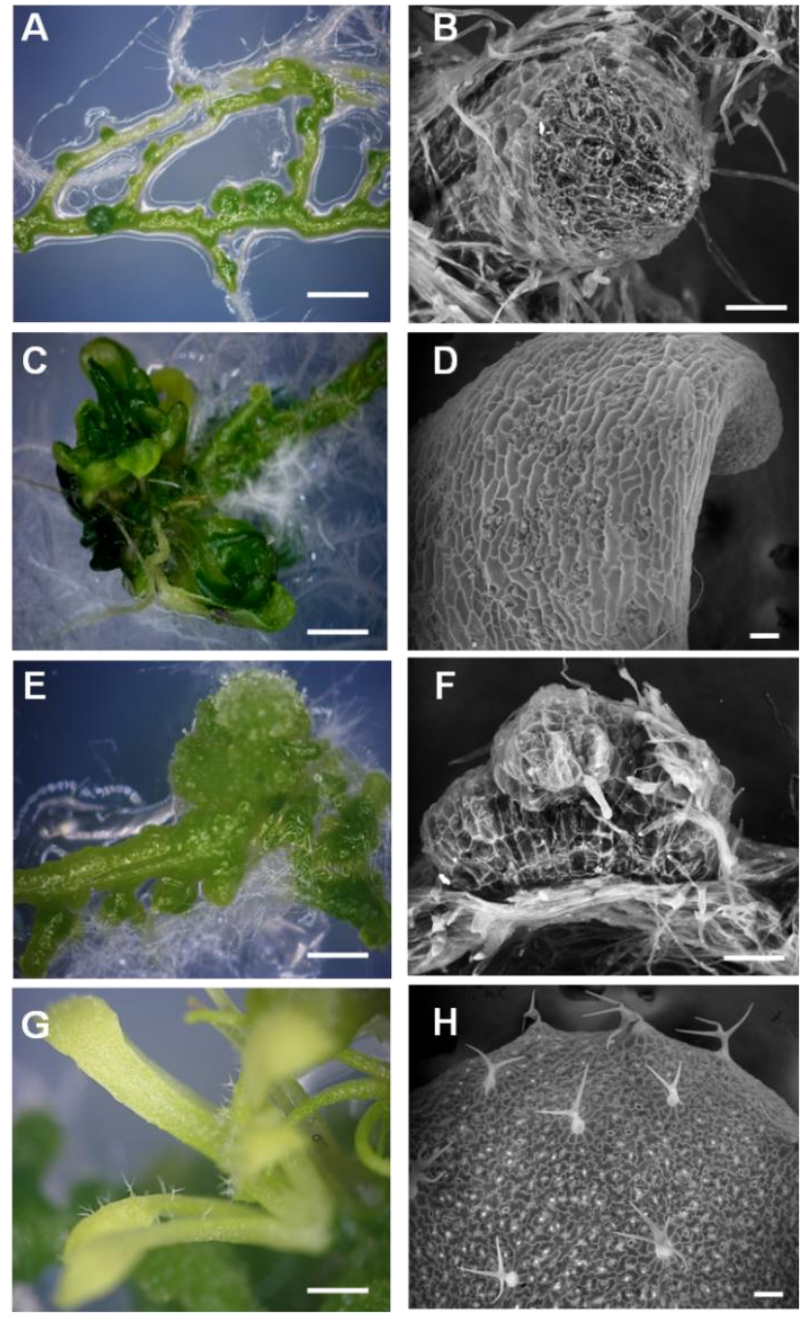

\section{1. ábra: Col gyökér explantumok regenerációja.}

Növények regenerációja HM lemezeken 4 napos citokinin indukciót követöen (A-D), illetve magas citokinin koncentráció folyamatos megléte mellett $(\boldsymbol{E}-\boldsymbol{H})$. Az átmeneti 4 napos citokinin indukciót követöen HM lemezeken 5 napig $(\boldsymbol{A}, \boldsymbol{B})$, valamint magas citokinin/alacsony auxin tartalmú ARM IIr táptalajon 9 napig (E, $\boldsymbol{F})$ tenyésztett gyökér explantumok $(\boldsymbol{A}, \boldsymbol{E})$ valamint azok morfogenikus régióinak képe $(\boldsymbol{B}, \boldsymbol{F}) . A$ regenerátumok leveleinek képe 2 héttel később $(\boldsymbol{C}, \boldsymbol{D}, \boldsymbol{G}, \boldsymbol{H})$. A képek sztereomikroszkóppal $(\boldsymbol{A}, \boldsymbol{C}, \boldsymbol{E}, \boldsymbol{G})$, illetve pásztázó elektronmikroszkóppal $(\boldsymbol{B}, \boldsymbol{D}, \boldsymbol{F}, \boldsymbol{H})$ készültek. A mércék $1 \mathrm{~mm}-\mathrm{t}(\boldsymbol{A}, \boldsymbol{C}, \boldsymbol{E}, \boldsymbol{G})$, valamint 100 $\mu m-t(\boldsymbol{B}, \boldsymbol{D}, \boldsymbol{F}, \boldsymbol{H})$ mutatnak. 

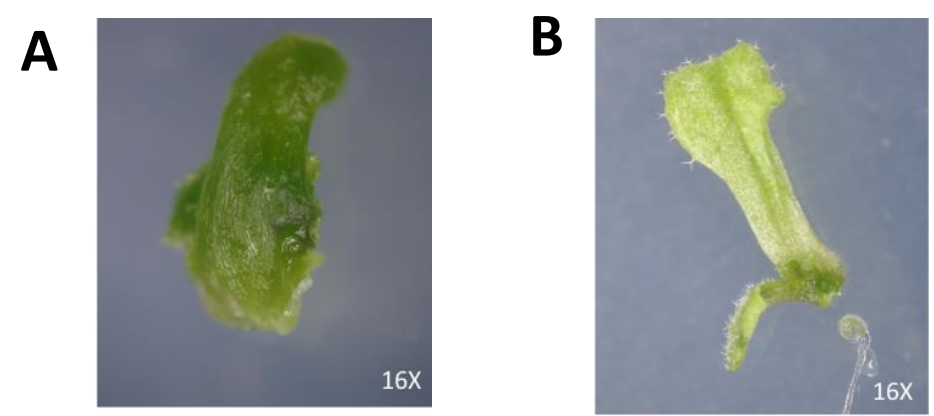

12. ábra: Col regenerált növényeinek sziklevele (SE) és valódi levele (hajtás organogenezis).

HM lemezeken 4 napos citokinin indukciót követöen Col gyökér explantumon megjelenö, SE eredményeként kialakult trichóma nélküli sziklevél $(\boldsymbol{A})$, illetve magas citokinin koncentráció folyamatos megléte mellett hajtás organogenezis útvonalon keresztül kialakult trichómával rendelkezö valódi levél (B) sztereomikroszkópos képei (nagyítás: 16x).

\subsubsection{Génkifejeződési vizsgálatok}

Annak bizonyítására, hogy az előzetesen auxin és citokinin indukált, HM lemezen levő gyökér explantumok felületén képződő trichóma nélküli regenerátumok SE eredményeképpen jöttek létre, megnéztük, hogyan változik az embriógenezis marker gének közül a $L E C 1$, a $L E C 2$ és a FUS3 relatív expressziós szintje (13. ábra). Azt tapasztaltuk, hogy a kontrollhoz képest mindhárom vizsgált gén expressziója megemelkedett.

Azonban, ha a gyökér explantumokat folyamatosan magas citokinin tartalmú táptalajon tartottuk, a vizsgált embriogén gének közül egyiknek sem növekedett az expressziós szintje, mely arra utal, hogy ebben az esetben nem SE, hanem hajtás organogenezis történt (13. ábra). 

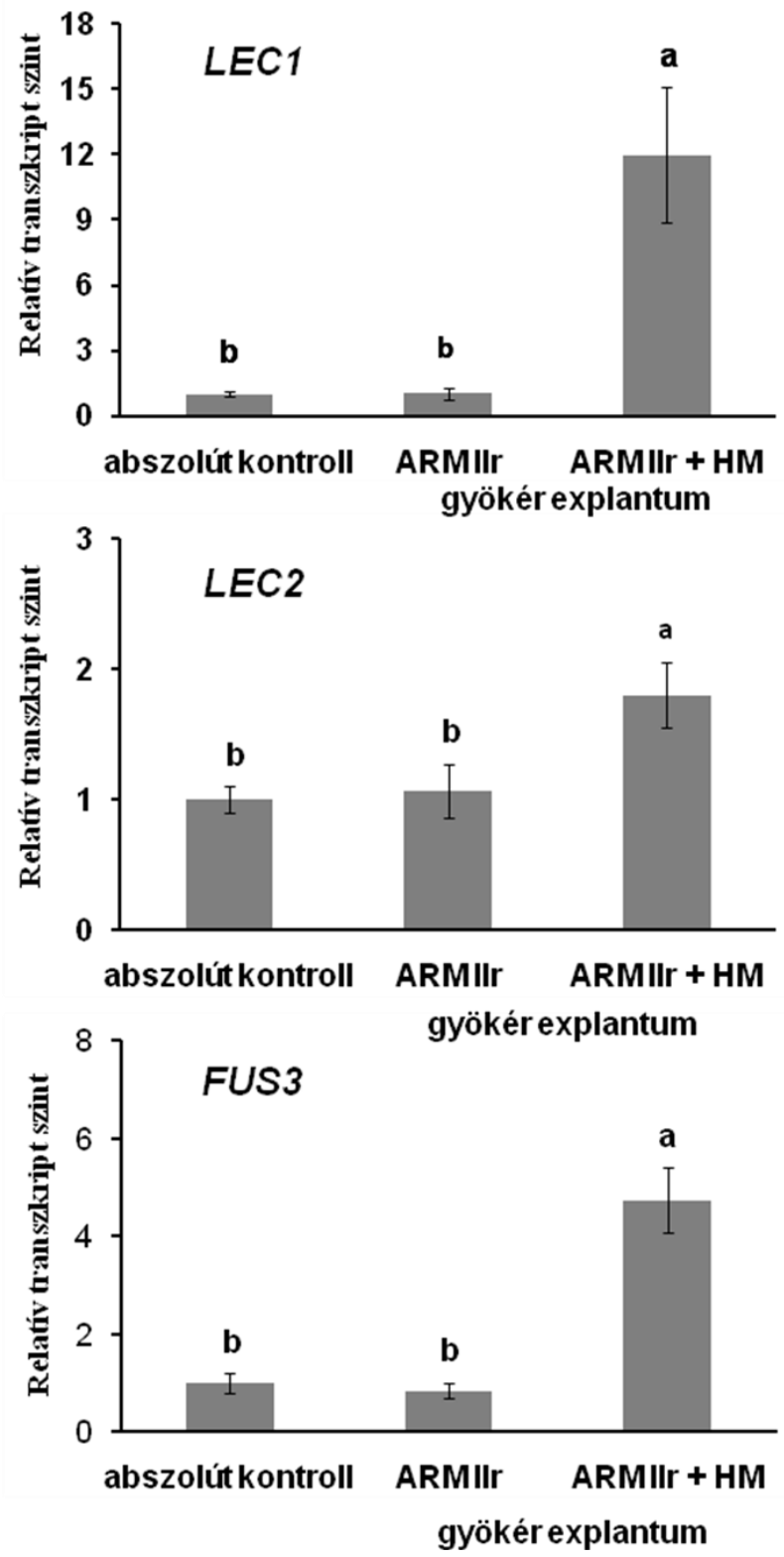

13. ábra: LEAFY COTYLEDON 1 (LEC1), LEAFY COTYLEDON 2 (LEC2), FUSCA 3 (FUS3) gének kifejeződése.

A LEC1, LEC2, FUS3 gének expresszióját 9 napja magas citokinin tartalmú lemezen levö (ARM IIr), valamint 5 napja HM lemezen levö, elözetesen 4 napig citokinin indukált (ARM IIr + HM) Col gyökér explantumokban, 1 hetes kezeletlen csíranövény gyökeréhez viszonyítva (abszolút kontroll=1) néztük. Az oszlopokon a hibasávok a standard hibát mutatják. Az egyszempontos varianciaanalízist követöen a Duncan-

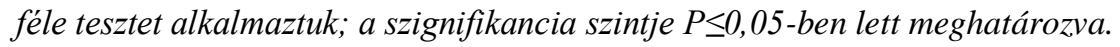


Ezt követően megvizsgáltuk, hogy a citokinin indukció első 4 napjában hogyan változik az organogenezisben részt vevő gének közül a CUC1, CUC2, ESR1, ESR2, illetve az embriógenezisben részt vevő $L E C 1, L E C 2$ és $F U S 3$ expressziós szintje. Azt tapasztaltuk, hogy míg a hajtás organogenezisben szerepet játszó gének expressziós szintje emelkedett (14. ábra), addig az embriógenezisben szerepet játszó gének csökkent expressziós szintet mutattak (15. ábra).
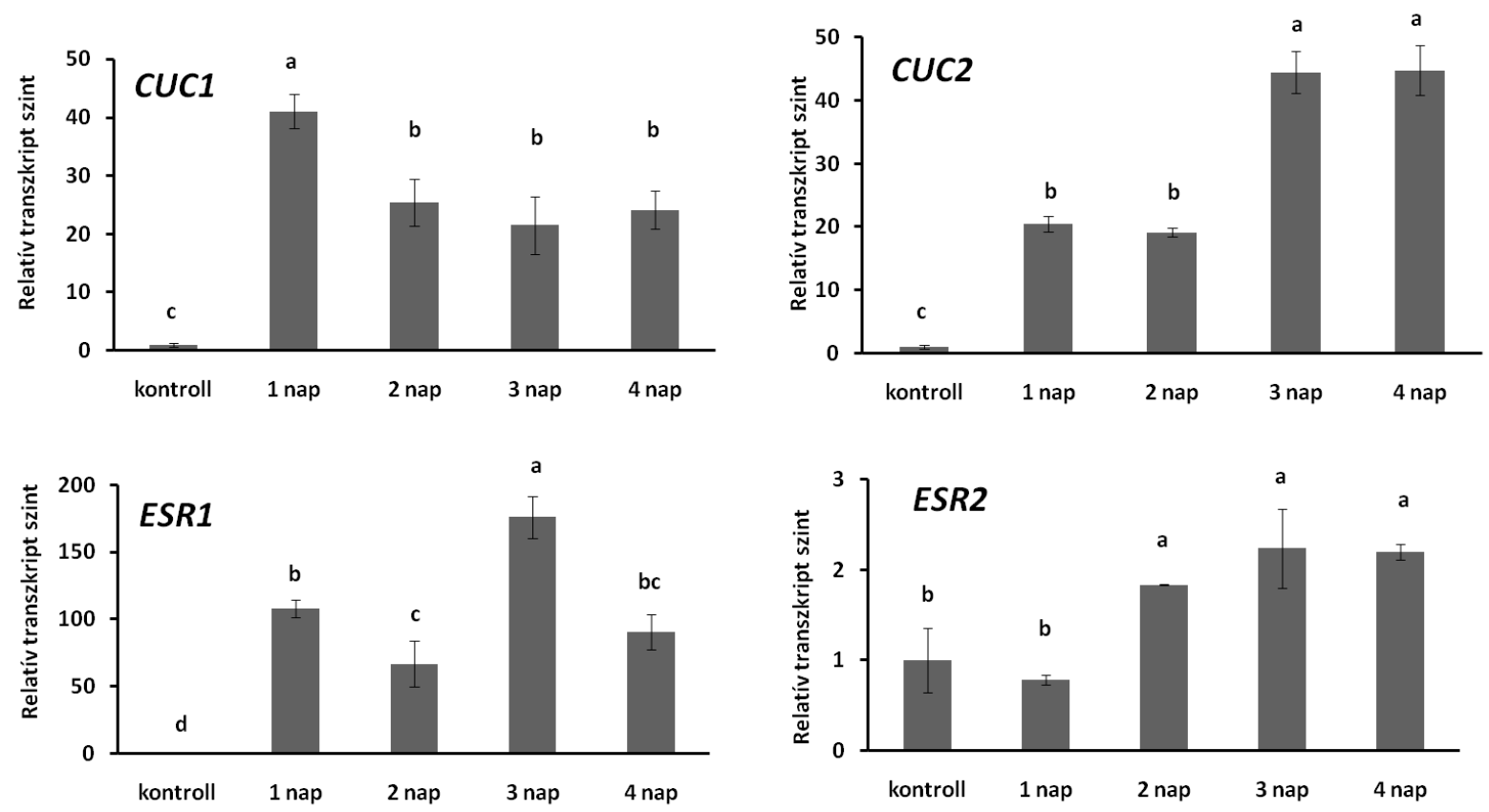

14. ábra: CUP-SHAPED COTYLEDON 1, 2 (CUC1, CUC2), ENHANCER OF SHOOT REGENERATION 1, 2 (ESR1, ESR2) gének kifejeződése.

A CUC1, CUC2, ESR1, ESR2 gének expresszióját 1-4 napja magas citokinin tartalmú ARM IIr lemezen levö Col gyökér explantumokban, 1 hetes kezeletlen csíranövény gyökeréhez viszonyítva (kontroll=1) vizsgáltuk. Az oszlopokon a hibasávok a standard hibát mutatják. Az egyszempontos varianciaanalizist követöen a Duncan-féle tesztet alkalmaztuk; a szignifikancia szintje P $\leq 0,05$-ben lett meghatározva. 


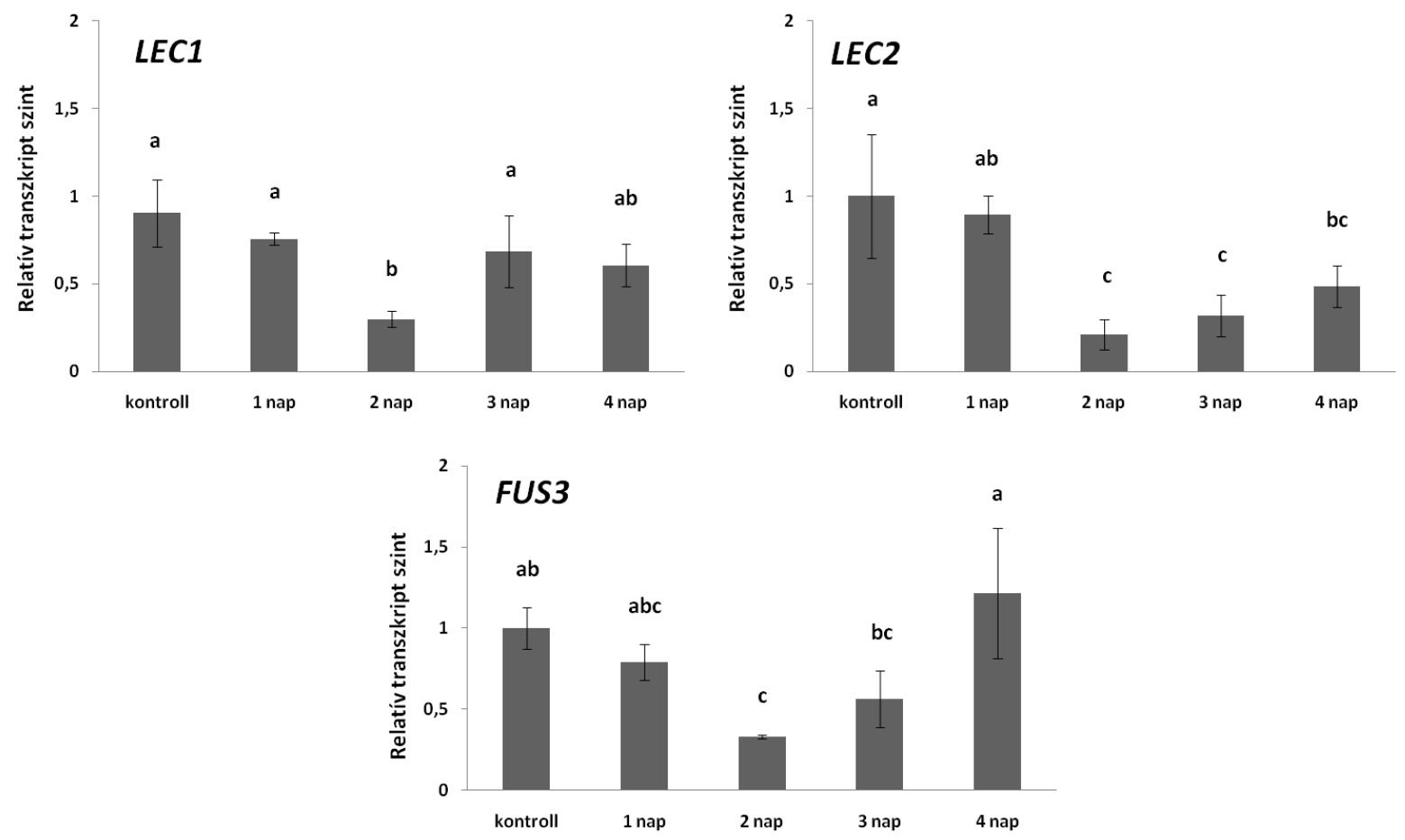

15. ábra: LEC1, LEC2, FUS3 gének kifejeződése.

A LEC1, LEC2, FUS3 gének expresszióját 1-4 napja magas citokinin tartalmú ARM IIr lemezen levö Col gyökér explantumokban, 1 hetes kezeletlen csíranövény gyökeréhez viszonyítva (kontroll=1) néztük. Az oszlopokon a hibasávok a standard hibát mutatják. Az egyszempontos varianciaanalizist követöen a Duncanféle tesztet alkalmaztuk; a szignifikancia szintje P $\leq 0,05$-ben lett meghatározva.

\subsubsection{3 lec1 mutáns vizsgálata}

Kíváncsiak voltunk arra is, hogy mi történik abban az esetben, ha lec1 mutáns csíranövény gyökereit tenyésztjük a fent bemutatott kísérleti rendszerben (16. ábra A, C; 3. táblázat). 


\begin{tabular}{|c|c|c|c|c|}
\hline Növényi anyag & $\begin{array}{c}\text { Regenerációs } \\
\text { gócok } \\
\text { száma/gyökér }\end{array}$ & $\begin{array}{c}\text { Regeneráció } \\
\text { gócokból }(\%)^{\mathrm{b}}\end{array}$ & $\begin{array}{c}\text { Trichóma } \\
\text { nélküli } \\
\text { regenerátumok } \\
(\%)^{\mathrm{c}}\end{array}$ & $\begin{array}{c}\text { Trichómás } \\
\text { regenerátumok } \\
(\%)^{\mathrm{c}}\end{array}$ \\
\hline $\begin{array}{c}\text { Col gyökér } \\
\text { explantum }\end{array}$ & $\mathbf{8} \pm \mathbf{0 . 8}$ & $\mathbf{6 5 . 6} \pm \mathbf{3 . 7}$ & $\mathbf{5 6 . 9} \pm \mathbf{4 . 7}$ & $\mathbf{4 3 . 1 \pm 4 . 7}$ \\
\hline $\begin{array}{c}\text { lec1 gyökér } \\
\text { explantum }\end{array}$ & $\mathbf{3 . 9 \pm 0 . 4}$ & $\mathbf{2 3 . 8} \pm \mathbf{6 . 9}$ & $\mathbf{0 . 0 \pm 0 . 0}$ & $\mathbf{1 0 0 \pm 0 . 0}$ \\
\hline
\end{tabular}

3. táblázat: Vad típusú Col és lec1 mutáns gyökér explantumok regenerációs hatékonysága és típusa.

${ }^{a}$ Zöld morfogén gócok gyökér explantumonként (hormonmentes lemezen 5. nap után számolva). Átlag standard hibája.

${ }^{b} A$ potenciális morfogén gócok azon százaléka, melyekböl teljes növény regenerálódott explantumonként. Átlag standard hibája.

'Azon regenerálódott növények százaléka, melyek valódi levelekkel/sziklevelekkel rendelkeztek trichómával/trichóma nélkül. Átlag standard hibája.

Lec1 gyökér explantumokat folyamatosan citokinin tartalmú táptalajon tartva (16. ábra A) a vad típushoz (16. ábra B) hasonló választ kaptunk, azaz zöldülést, kalluszképződést, vastagodást, majd később organogenezis eredetü hajtások megjelenését. Amennyiben a citokinin indukciót követő 4. napon HM táptalajra helyeztük a lecl gyökér explantumokat, a kallusz képződése korlátozódott és a potenciálisan morfogén lókuszok száma a vad típushoz (16. ábra D) képest közel 50\%-kal kevesebb volt (16. ábra C; 3. táblázat). Mindemellett lecl gyökerekből csupán trichómával rendelkező regenerátumok képződtek HM táptalajon (3. táblázat). 

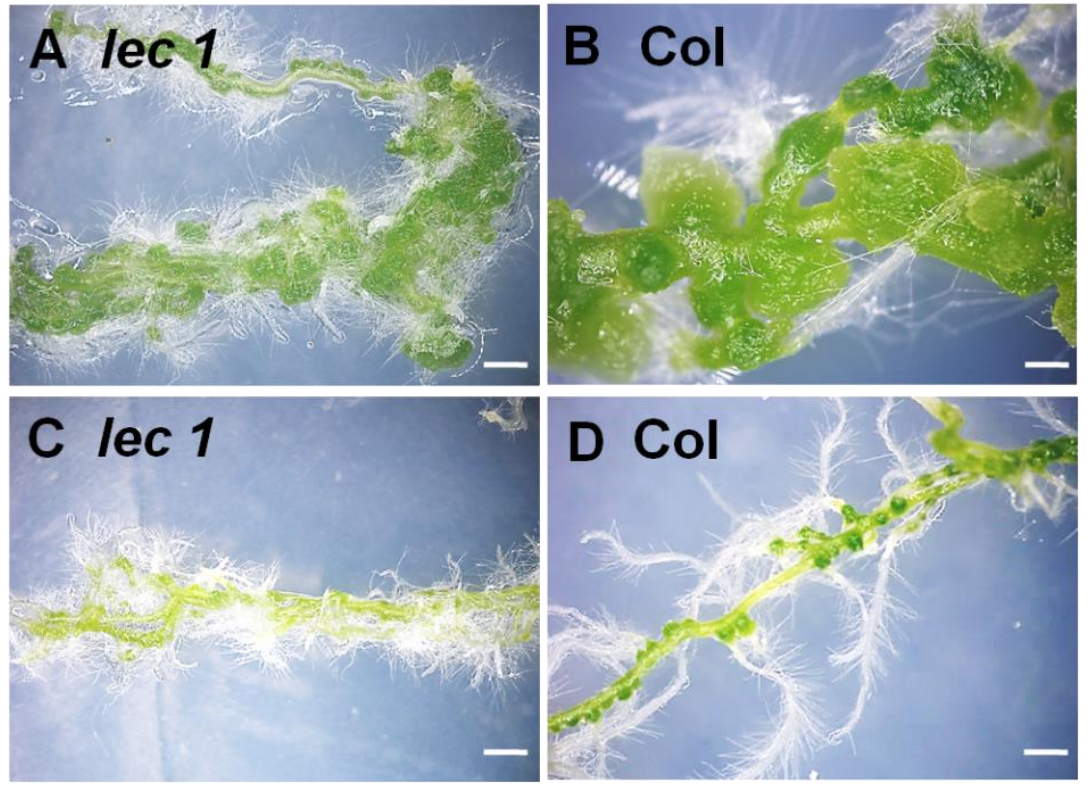

\section{6. ábra: Lec1 mutáns és vad típusú Col gyökér explantumok regenerációja.}

Az ábra a lecl gyökér explantumok $(\boldsymbol{A}, \boldsymbol{C})$, valamint a vad típusú Col gyökér explantumok (B, D) regenerációs hatékonyságát mutatja folyamatos magas citokinin koncentráció $(\boldsymbol{A}, \boldsymbol{B})$ esetén, valamint 4 napos citokinin indukciót követöen HM körülmények $(\boldsymbol{C}, \boldsymbol{D})$ alatt. A képek ARM IIr táptalajon 9 napig $(\boldsymbol{A}, \boldsymbol{B})$, valamint 4 napos citokinin indukciót követöen HM táptalajon 5 napig $(\boldsymbol{C}, \quad \boldsymbol{D})$ tenyésztett gyökér explantumokról készültek (sztereomikroszkópos képek, mérce $1 \mathrm{~mm}$ ). 


\subsubsection{A hajtáseredetü auxin hatása a gyökér regenerációs folyamataira}

\subsubsection{Sztereomikroszkóppal végzett morfológiai vizsgálatok}

Érdekes módon, ha kísérleti rendszerünkben teljes csíranövényeket használtunk gyökér explantumok helyett, elmaradt a regenerátum-képződés. Ha a teljes növényeket folyamatosan magas citokinin tartalmú táptalajon (ARM IIr) tartottuk, azok gyökerei megvastagodtak, zöldültek, de sem kalluszképződést, sem hajtásképződést nem tapasztaltunk (17. ábra A). Ha ezeket a növényeket HM táptalajra helyeztük a citokinin kezelést követő 4. napon, a vastagodás és a zöldülés is elmaradt (17. ábra B; 4. táblázat).

\begin{tabular}{|c|c|c|c|c|c|}
\hline Növényi anyag & TIBA & $\begin{array}{c}\text { Regenerációs } \\
\text { gócok } \\
\text { száma/gyökér }\end{array}$ & $\begin{array}{c}\text { Regeneráció } \\
\text { gócokból }(\%)^{\mathrm{b}}\end{array}$ & $\begin{array}{c}\text { Trichóma } \\
\text { nélküli } \\
\text { regenerátumok } \\
(\%)^{\mathrm{c}}\end{array}$ & $\begin{array}{c}\text { Trichómás } \\
\text { regenerátumok } \\
(\%)^{\mathrm{c}}\end{array}$ \\
\hline Col teljes növény & - & $\mathbf{0 . 0 \pm 0 . 0}$ & $\mathbf{0 . 0 \pm 0 . 0}$ & $\mathbf{0 . 0} \pm \mathbf{0 . 0}$ & $\mathbf{0 . 0 \pm 0 . 0}$ \\
\hline Col teljes növény & + & $\mathbf{6 . 8} \pm \mathbf{0 . 8}$ & $\mathbf{4 3 . 8 \pm 4 . 5}$ & $\mathbf{4 8 . 3} \pm \mathbf{3 . 9}$ & $\mathbf{5 1 . 7} \pm \mathbf{3 . 9}$ \\
\hline
\end{tabular}

4. táblázat: Vad típusú Col teljes növények gyökereinek regenerációs hatékonysága és típusa TIBA hozzáadása nélkül (-) vagy TIBA kezeléssel (+).

${ }^{a}$ Zöld morfogén gócok gyökér explantumonként (hormonmentes lemezen 5. nap után számolva). Átlag standard hibája.

${ }^{b} A$ potenciális morfogén gócok azon százaléka, melyekböl teljes növény regenerálódott explantumonként. Átlag standard hibája.

'Azon regenerálódott növények százaléka, melyek valódi levelekkel/sziklevelekkel rendelkeztek trichómával/trichóma nélkül. Átlag standard hibája.

Megfigyeléseink alapján feltételeztük, hogy a hajtásból a gyökérbe transzportálódó auxinnak hatása lehet az embrióképződés, illetve a hajtás organogenezis indukciójára. A hajtáseredetü auxin regenerációs potenciálra gyakorolt lehetséges hatásának vizsgálatára auxin 
transzport inhibítort, TIBA-t használtunk. A gátlószert alacsony olvadáspontú agaróz cseppben, 5 $\mu \mathrm{M}$ koncentrációban helyeztük az epikotil-hipokotil találkozási pontjára.

TIBA kezelés hatására helyreállt a regenerációs potenciál (17. ábra C, D; 4. táblázat). A gyökér explantumokhoz hasonlóan (17. ábra E, F) a TIBA kezelt csíranövények gyökerei csupán trichómával rendelkező hajtásokat regeneráltak magas citokinin tartalmú ARM IIr lemezeken. Amennyiben a TIBA kezelt növényeket az átmeneti 4 napos citokinin indukciót követően HM lemezeken tenyésztettük, a gyökerek felszínén kifejlődött regenerátumok megközelítőleg 50\%-a trichóma nélküli volt (4. táblázat).
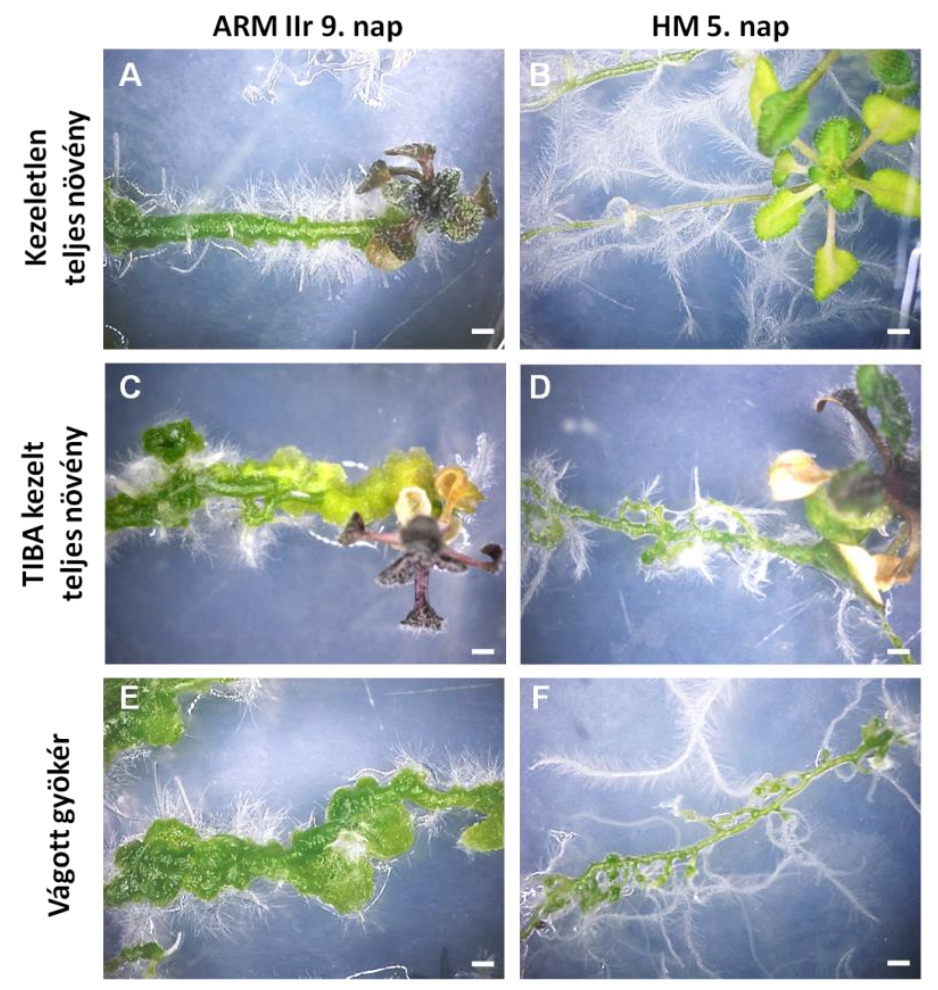

17. ábra: Col kezeletlen teljes növények, TIBA kezelt teljes növények és gyökér explantumok válaszai ARM IIr és HM táptalajokon.

Col teljes növények gyökerének (A-D), valamint kontrollként használt vágott gyökerek $(\boldsymbol{E}, \boldsymbol{F})$ növényregenerációja magas citokinin koncentrácójú ARM IIr táptalajon $(\boldsymbol{A}, \boldsymbol{C}, \boldsymbol{E})$, illetve átmeneti 4 napos citokinin indukciót követöen HM táptalajon $(\boldsymbol{B}, \boldsymbol{D}, \boldsymbol{F})$. Teljes növények egy részét $5 \mu M$ TIBA-val kezeltük agaróz csepp segítségével a hajtás és a gyökér találkozási pontján $(\boldsymbol{C}, \boldsymbol{D})$. A képek ARM IIr táptalajon a 9. napon $(\boldsymbol{A}, \boldsymbol{C}, \boldsymbol{E})$, valamint 4 napos citokinin indukciót követöen $H M$ táptalajon az 5. napon $(\boldsymbol{B}, \boldsymbol{D}, \boldsymbol{F})$ készültek (sztereomikroszkópos képek, mérce: $1 \mathrm{~mm}$ ). 


\subsubsection{Génkifejeződési vizsgálatok}

Ezután megnéztük, hogy TIBA kezelés hatására hogyan alakul az embriógenezisben részt vevő gének közül a LEC1, a LEC2 és a FUS3 expressziós szintje a gyökér explantumokhoz képest. Ezen markerek génekexpressziós szintje a vágott gyökér explantumokhoz hasonló mértékben megemelkedett (18. ábra), igazolva, hogy a hajtáseredetü auxin gyökérbe irányuló transzportjának gátlása elegendő a csíranövény gyökerében a regenerációs képesség kialakítására és hogy a keletkezett regenerátumok egy része SE eredményeképpen jött létre. Ez utóbbit az is jelezte, hogy a regenerátumok közel 50\%-ának az első levelei nem rendelkeztek trichómákkal (4. táblázat).

A sebzésről és a sebzés által indukált WIND1 transzkripciós faktorról kimutatták, hogy központi szerepük van a gyökér explantumok (vágott gyökerek) regenerációs potenciáljában (Iwase és mtsai., 2015). Az intakt csíranövények vágatlan gyökerei, ahogy azt a fentebbiekben mi is bemutattuk, nem regenerálnak hajtást auxin és citokinin indukciót követően. A WIND1 TF túltermelése a csíranövények gyökerében is lehetővé teszi a regenerációs folyamatok elindulását, hasonlóan a vágott gyökerekhez (Iwase és mtsai., 2015). Ezért megvizsgáltuk, miként változik a WIND1 expressziós szintje TIBA kezelés nélküli teljes növények gyökereiben, gyökér explantumokban, illetve TIBA kezelt teljes növények gyökereiben. A sebzéshez hasonlóan (gyökér explantumok), a TIBA kezelés által gátolt auxin transzportnak köszönhetően is magasabb WIND1 expressziós szintet figyeltünk meg teljes növények gyökerében - a TIBA kezelés eredményeként megnövekedett regenerációs potenciálnak megfelelően (18. ábra). Megfigyeléseink arra engednek következtetni, hogy mind a hajtás, mint auxin forrás eltávolítása, mind a hajtás-gyökér irányú auxin transzport TIBA általi blokkolása megnövekedett WIND1 expressziót és fokozott kallusz/hajtás/embrióképződést eredményez megfelelő induktív körülmények mellett a gyökérben. 

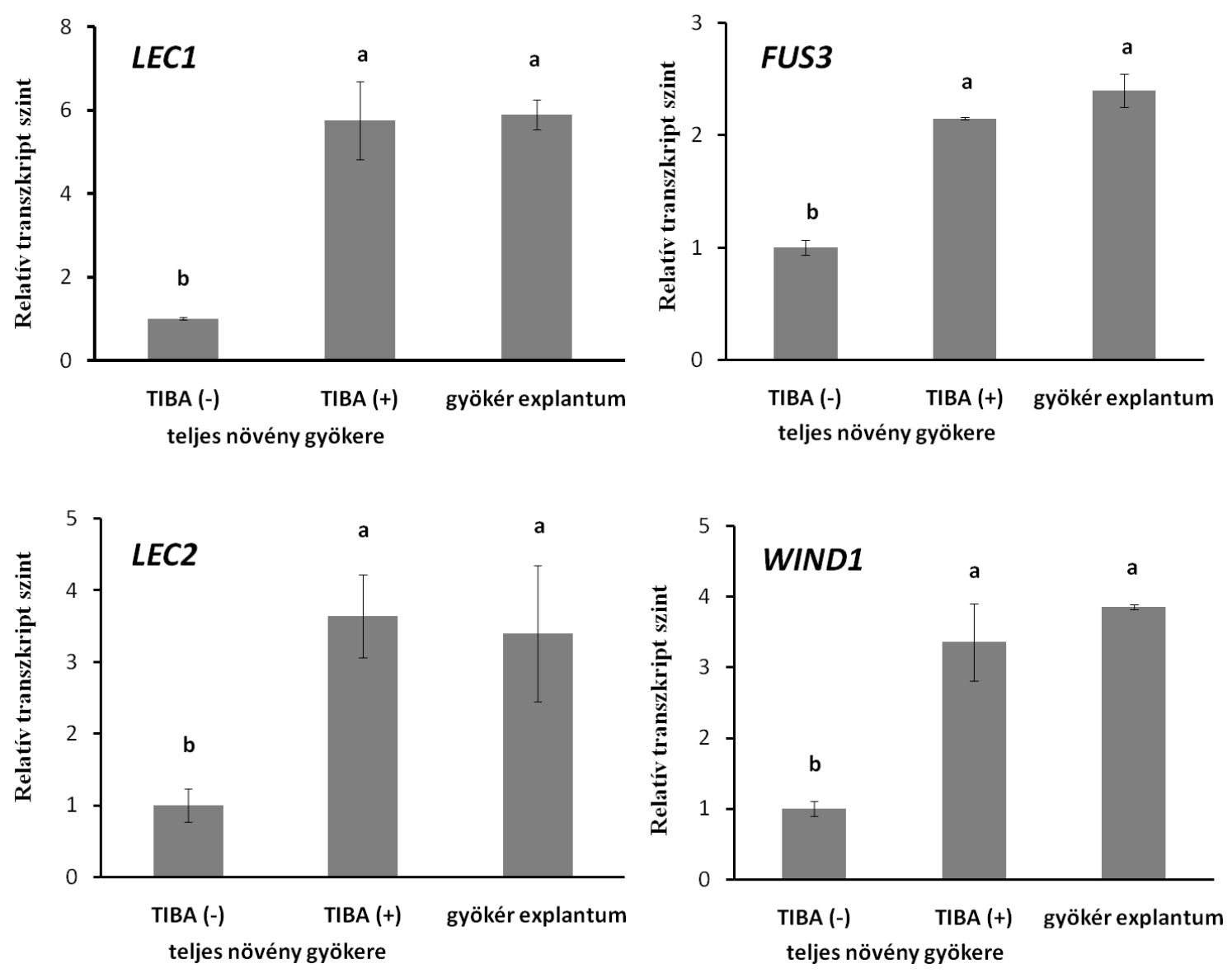

18. ábra: LEC1, LEC2, FUS3, WOUND-INDUCED DEDIFFERENTIATION 1 (WIND1) gének kifejeződése.

Vizsgáltuk a LEC1, LEC2, FUS3, WIND1 gének relatív transzkript szintjeit a citokinin indukciót követöen 5 napja HM lemezen levö TIBA kezelt (TIBA (+)) teljes növények gyökereiben, valamint a kezelés nélküli vágott gyökerekben (gyökér explantum), a HM lemezen 5 napja levö kezeletlen teljes növények gyökereiböl vett mintához viszonyítva (TIBA $(-)=1)$. Az oszlopokon a hibasávok a standard hibát mutatják. Az egyszempontos varianciaanalizist követöen a Duncan-féle tesztet alkalmaztuk; a szignifikancia szintje P $\leq 0,05$-ben lett meghatározva

\subsubsection{3 lec1 mutáns vizsgálata}

A TIBA kezelt lecl csíranövények gyökerei citokinin indukciós ARM IIr lemezeken, valamint az átmeneti 4 napos citokinin indukciót követően HM lemezeken is csupán trichómával rendelkező növényeket regeneráltak (5. táblázat), TIBA kezelés nélkül pedig a vad típushoz hasonlóan elmaradt a regeneráció. A lec1 mutánssal kapott eredmények megerősítették, hogy a 
hajtás eltávolítása ("sebzés") és a lokális TIBA kezelés, vagyis a hajtás-gyökér auxin transzport megakadályozása hasonló módon javítja a gyökér regenerációs képességét, függetlenül attól, hogy a regeneráció SE-t vagy hajtás organogenezist jelent.

\begin{tabular}{|c|c|c|c|c|c|}
\hline Növényi anyag & TIBA & $\begin{array}{c}\text { Regenerációs } \\
\text { gócok } \\
\text { száma/gyökér }\end{array}$ & $\begin{array}{c}\text { Regeneráció } \\
\text { gócokból }(\%)^{\mathrm{b}}\end{array}$ & $\begin{array}{c}\text { Trichóma } \\
\text { nélküli } \\
\text { regenerátumok } \\
(\%)^{\mathrm{c}}\end{array}$ & $\begin{array}{c}\text { Trichómás } \\
\text { regenerátumok } \\
(\%)^{\mathrm{c}}\end{array}$ \\
\hline lec1 teljes növény & - & $\mathbf{0 . 0 \pm 0 . 0}$ & $\mathbf{0 . 0} \pm \mathbf{0 . 0}$ & $\mathbf{0 . 0 \pm 0 . 0}$ & $\mathbf{0 . 0} \pm \mathbf{0 . 0}$ \\
\hline lec1 teljes növény & + & $\mathbf{3 . 3} \pm \mathbf{0 . 4}$ & $\mathbf{1 5 . 0 \pm 5 . 1}$ & $\mathbf{0 . 0 \pm 0 . 0}$ & $\mathbf{1 0 0 . 0 \pm 0}$ \\
\hline
\end{tabular}

\section{5. táblázat: lec1 mutáns teljes növények gyökereinek regenerációs hatékonysága és típusa TIBA} hozzáadása nélkül (-) vagy TIBA kezeléssel (+).

${ }^{a}$ Zöld morfogén gócok gyökér explantumonként (hormonmentes lemezen 5. nap után számolva). Átlag standard hibája.

${ }^{b} A$ potenciális morfogén gócok azon százaléka, melyekböl teljes növény regenerálódott explantumonként. Átlag standard hibája.

cAzon regenerálódott növények százaléka, melyek valódi levelekkel/sziklevelekkel rendelkeztek trichómával/trichóma nélkül. Átlag standard hibája. 


\section{EREDMÉNYEK ÉRTÉKELÉSE}

\subsection{A citokinin megfelelő időben történő eltávolítása két regenerációs útvonal megjelenését indukálja}

Míg a szomatikus embriógenezis (SE) legelterjedtebb indukálószere az auxin, különösen a mesterséges auxin (2,4-diklórfenoxi-ecetsav (2,4-D)) (Overbeek és mtsai., 1951), a citokininek SEre gyakorolt hatása változó (például Mujib és mtsai., 2016). A legtöbb rendszerben alacsony citokinin szintet alkalmaznak auxinnal együtt az embrió indukciójának elősegítése érdekében, míg más esetekben az exogén citokininek gátolják az auxin által indukált SE-t. Néhány rendszerben a citokininek hatékonynak bizonyultak az embrióképződés egyetlen indukálójaként (Sagare és mtsai., 2000; Gaj, 2004; Chung és mtsai., 2005). Arabidopsis-ban ugyanakkor még nem számoltak be a SE citokininnel történő indukciójáról.

A citokinineket (auxinnal vagy auxin nélkül) széles körben alkalmazzák de novo hajtásmerisztémák indukciójára in vitro. Az endogén citokinin szint növekedését eredményező mutációk vagy transzgének is segítik a hajtás kialakulását (Chaudhury és mtsai., 1993; Kakimoto, 2001; Catterou és mtsai., 2002; Sun és mtsai., 2003), míg a csökkent citokinin szintézishez vezető mutációk gátolják ezt a folyamatot (Cheng és mtsai., 2013).

Rendszerünkben az auxin (ARM I), majd citokinin (ARM IIr) indukciót követően egy megfelelő időintervallumban (4 napos citokinin indukció) HM tápközegre került Col gyökér explantumok felületén regenerálódott növények közel 50\%-a trichóma nélküli, kotiledonszerű első levelekkel rendelkezett (2. táblázat), mely feltételezi azok embriogén eredetét. A trichóma hiánya az elsőként megjelenő leveleken gyakorta használt morfológiai markere a SE-nek, bár ez a marker félrevezető is lehet, ha a levélszőrök késve jelennek meg (Horstman és mtsai., 2017).

Gyakran használják az embriogén fejlődési út markereként a LEC1 (Gaj és mtsai., 2005), valamint a LEC2 géneket (Wójcikowska és mtsai., 2013). A FUS3 expressziója nem köthető a SE egy bizonyos szakaszához, kifejeződése azonban specifikus az embriogén kultúrákban (Gaj, 2011). FUS3 hiányában a hajtásregeneráció hatékonysága nő, míg az embriógenezisé csökken (Gaj és mtsai., 2005). A citokininről kimutatták, hogy gátolja a SE-ben kulcs szereppel bíró LEC2 és FUS3 TF-ok expresszióját (Casson és Lindsey, 2006; Horstman és mtsai., 2017). 
Rendszerünkben a magas koncentrációjú külső citokinin eltávolítása valószínűleg egyfajta átkapcsolást indukált a két regenerációs útvonal között. Erre utalnak a génexpressziós adatok, melyek alapján a citokinin az organogenezis géneket (CUC1, CUC2, ESR1, ESR2) indukálja (14. ábra), míg az embriógenezis-kapcsolt gének (LEC1, LEC2, FUS3) kifejeződését csak az exogén citokinin eltávolítása után lehet kimutatni (13. ábra). Mindezek alapján az a hipotézisünk, hogy kezdetben hajtásregeneráció indukálódik, majd a citokinin eltávolítását követően a hajtás primordium embriószerü struktúrává (szomatikus embrió) transzdifferenciálódik, ám az átalakulásoknak csak egy része (közel fele) történik, ami magyarázza a hajtás primordiumok/embriók vegyes megjelenését.

Kísérleteink során a trichóma nélküli levelekkel rendelkező regenerátumok csupán olyan körülmények között jelentek meg, amikor az embriogén marker gének is indukálódtak, a direkt SEdefektív homozigóta lecl mutáns (Gaj és mtsai., 2005) gyökér explantumok felületén ugyanakkor nem jelentek meg. Azon megfigyelés, miszerint a lecl mutánsok esetén képződött regenerációs gócok száma lecsökkent a vad típushoz képest - a regenerátumok száma csak közel fele volt a vad típus esetén megfigyeltnek (3. táblázat) - azt jelzi, hogy a hajtásregeneráció - SE átkapcsolás gyorsan megtörténik és a LEC1 kifejeződését megelőzi. Feltehetően a külső citokinin eltávolítása hatással volt az endogén citokinin vagy auxin szintézisre és/vagy transzportra, befolyásolva a regenerációs útvonalat.

A szomatikus embriók nem mutattak egyértelműen bipoláris struktúrát rendszerünkben, melynek oka feltehetően az ARM IIr táptalajban található magas kezdeti citokinin szint és ezáltal a gyökér morfogenezis (gyökérmerisztéma-képződés) gátlása. Úgy tűnik, a citokinin eltávolításával ez a folyamat már nem fordítható vissza az embriógenezis-kapcsolt transzkripciós faktorok (LEC1, LEC2, FUS3) által sem.

A két regenerációs útvonal (hajtás organogenezis és SE) párhuzamos megjelenését leírták korábban alacsony koncentrációjú benziladeninnel kezelt Solanum carolinense explantumoknál, míg magasabb koncentráció alkalmazásakor csupán hajtás organogenezist figyeltek meg (Reynolds, 1986). Napraforgó (Helianthus annuus L.) szövettenyészetben a magas cukor koncentráció idézte elő a hajtás organogenezis - SE közötti átkapcsolást, melyet részben a tápközegböl történő csökkent citokinin felvételnek tulajdonítottak (Charrière és Hahne, 1998). Ezeket a megfigyeléseket magyarázhatja a citokinin SE-re gyakorolt gátló hatása.

Feltételezhetően az indirekt hajtás organogenezis és az indirekt SE ugyanazokkal a kezdeti lépésekkel rendelkeznek, legalábbis a hajtásmerisztéma kialakulását illetően (Su és mtsai., 2009; Cheng és mtsai., 2013; Su és Zhang, 2014; Su és mtsai., 2015). A hajtás primordium és a szomatikus embriók ugyanazon sejttípusból történő eredetét bizonyították már számos rendszerben, 
alátámasztva azt a tényt, mely szerint a két útvonal kezdeti lépései hasonlóságokat mutatnak (Bronner és mtsai., 1994; Yumbla-Orbes és mtsai., 2017). Az exogén/endogén hormon szintek időbeli változása lehetővé teheti mindkét útvonal párhuzamos megjelenését különböző, vagy akár ugyanazon regenerációs gócokban.

Számos fejlődésbiológiai rendszerben kimutatták, hogy a citokinin és az auxin kölcsönösen szabályozzák egymás szintjeit, továbbá megfigyelték, hogy a citokinin gátolja a poláris auxin transzportot (Pernisová és mtsai., 2011; Schaller és mtsai., 2015). Mivel a citokinin eltávolításával indukált hormonális változás térben és időben nem egységes, így kerülhet sor a két regenerációs útvonal párhuzamos jelenlétére. Feltételezhető, hogy ha a megfelelő endogén hormonális változásokat nagy hatékonysággal és egységesen tudnánk előidézni (pl. a citokinin és/vagy auxin szintet szabályozó megfelelő génkonstrukciók kifejeztetésével), akkor az átkapcsolás is nagyobb hatékonysággal történhetne meg.

Eredményeink továbbá arra is utalnak, hogy az Arabidopsis gyökér explantumok növényregenerációja meglehetősen rugalmas és még ismeretlen kísérleti körülmények között is könnyen megváltoztatható (Kareem és mtsai,. 2016). Ez megmagyarázhatja a különböző laboratóriumokban tapasztalt változó hatékonyságokat és eltérő megfigyeléseket (Márton és Browse, 1991; Park és mtsai., 1993; Valvekens és mtsai., 1995; Kareem és mtsai., 2016 és a jelen munka).

\subsection{A hajtáseredetü auxin gátló hatással van a gyökér regenerációs folyamataira}

Napraforgó zigotikus embriók esetén vizsgálták a magas citokinin koncentrációnak és a poláris auxin transzport gátlásának in vitro növényregenerációra gyakorolt hasonló hatását. Ezek az explantumok 3\%-os szacharózt tartalmazó citokinin tartalmú táptalajon hajtásokat regeneráltak, míg 12\%-os szacharózt tartalmazó citokinin tartalmú indukciós táptalajon szomatikus embriók jelentek meg (Bronner és mtsai., 1994). Kimutatták, hogy a megnövekedett szacharóz koncentrációnak köszönhetően csökkent a citokinin felvétele és megnövekedett az endogén auxin/citokinin aránya mindezek összefüggésben álltak az embriogén válasszal (Charrière és mtsai., 1999). Az auxin transzport gátlása magas koncentrációjú szacharózt tartalmazó indukciós táptalajban gátolta a SE-t, ugyanakkor a hajtás morfogenezist elősegítette (Charrière és Hahne, 1998), mintegy utánozva az alacsony exogén szacharóz és magasabb endogén citokinin koncentrációk hatását. Más kísérleti rendszerekben, a poláris auxin transzport gátlók alkalmazása gátolta a SE-t vagy morfogenikus 
rendellenességekhez vezetett (Schiavone és Cooke, 1987; Grzyb és mtsai., 2018), habár speciális esetekben ezek alacsony koncentrációja a folyamat elösegítését is eredményezheti (Chen és Chang, 2004). A hajtásból származó auxin valamilyen módon megzavarja tehát a gyökérben a külső citokinin kezeléssel kiváltott indirekt regenerációs folyamatokat.

Az auxin transzport gátló 2,3,5-trijód-benzoesav (TIBA) SE-re gyakorolt hatása függ a genotípustól, az explantum típusától, a fejlődés stádiumától és az inhibítor dózisától. Alkalmazása egy széles körben használt megközelítés, amellyel a hajtás eredetű auxinnak a gyökér funkciókra gyakorolt hatását vizsgálták (például Reed és mtsai., 1998; Guo és mtsai., 2005). Rendszerünkben az ép gyökerek a külső citokinin kezelésre differenciálódással válaszolnak (vastagabb, zöldebb főgyökér; 17. ábra A), ám az előbbi megközelítést alkalmazva, a gátlószert agaróz cseppben az epikotil-hipokotil találkozási pontjára helyezve azt tapasztaltuk, hogy a sebzés nélküli Arabidopsis teljes növények gyökeréből folyamatos citokinin kezelés hatására hajtásregeneráció indukálódott. Amennyiben a TIBA kezelt növényeket az átmeneti 4 napos citokinin indukciót követően HM lemezeken tenyésztettük, a gyökerek felszínén regenerátumok fejlődtek ki, melyek megközelítőleg 50\%-a trichóma nélküli volt. Ezen TIBA kezelt növények gyökerében a LEC1, a LEC2 és a FUS3 embriógenezis marker gének expressziós szintje a gyökér explantumokhoz hasonló mértékben megemelkedett (18. ábra), igazolva, hogy a hajtáseredetű auxin gyökérbe irányuló transzportjának gátlása rendszerünkben elegendő a csíranövény gyökerében a regenerációs képesség kialakítására és hogy a keletkezett regenerátumok egy része SE eredménye. Intakt növények gyökerei ugyanakkor TIBA kezelés nélkül nem mutattak regenerációt sem HM lemezeken, sem citokinin folyamatos megléte mellett.

$\mathrm{Az}$ indirekt hajtásregeneráció érdekes sajátsága Arabidopsis-ban, hogy csupán vágott gyökerekből hatékony, teljes növények esetén elmarad a regeneráció (Iwase és mtsai., 2015) (17. ábra A, B). Ugyanakkor az oldalgyökér primordium hajtásmerisztémává történő direkt konverziója magas exogén citokinin koncentráció mellett megfigyelhető teljes növények gyökerénél is (Chatfield és mtsai., 2013; Rosspopoff és mtsai., 2017). Továbbá, magas endogén citokinin koncentrációval bíró mutáns vagy transzgénikus növények intenzív hajtásregenerációt mutatnak in vitro gyökér explantumokban, de teljes növények gyökerében nem (Chaudhury és mtsai., 1993; Kakimoto, 2001; Catterou és mtsai., 2002; Sun és mtsai., 2003). Mindez összhangban állhat azzal, hogy az átmeneti kalluszképződés első lépései az indirekt regeneráció során megegyeznek az oldalgyökerek képződésének kezdeti lépéseivel (Atta és mtsai., 2009), amihez pedig szükséges a hajtáscsúcsból a gyökér felé történő auxin transzport megléte (Reed és mtsai., 1998). 
A stresszkezelések - beleértve a sebzést - szorosan összefüggnek az in vitro növényregeneráció hatékony indukciójával (Zavattieri és mtsai., 2010; Iwase és mtsai., 2011a; 2011b; Ikeuchi és mtsai., 2013; Fehér, 2015; Iwase és mtsai., 2015; Sugimoto, 2015; Ikeuchi és mtsai., 2016). A sebzésről kimutatták, hogy a WIND1 transzkripciós faktor aktiválásán keresztül regenerációra képes kallusz kialakulásához vezet Arabidopsis gyökerekből (Iwase és mtsai., 2011a; 2011b; 2015; Ikeuchi és mtsai., 2016). A sebzés és a sebzés által indukált WIND1 TF, valamint a regenerációban fontos két fitohormon (auxin, citokinin) kapcsolatát vizsgálva megállapították többek között, hogy az endogén auxin szint nem változott jelentősen sebzett Arabidopsis hipokotilokban (Iwase és mtsai., 2017) és a WIND1 túltermelésnek sem volt megfigyelhető hatása a belső auxin szintre (Ikeda és Ohme-Takagi, 2014; Iwase és mtsai., 2017). Ugyanakkor kimutatták, hogy a WIND1 túltermelés aktiválta a citokinin szintézist és válaszokat (Iwase és mtsai., 2017).

Nemrégiben bebizonyosodott, hogy a WIND1 ektópiás expressziója fokozta a gyökér explantumokból történő de novo hajtásregenerációt. Ezenkívül a WIND1 expressziója megkerülheti a sebzés és az auxin elökezelés szükségességét: a WIND1-et kifejező intakt növények gyökerei reagálhatnak a hajtás kialakulását kiváltó körülményekre (Iwase és mtsai., 2015). A sebzésről ezért azt állították, hogy „elengedhetetlen a hajtások gyökerekből történő regenerálódásához Arabidopsis thaliana szövettenyészetekben” (Iwase és mtsai., 2015).

A HM lemezre helyezett intakt növények gyökerében az endogén citokinin szintézist/jelátvitelt szabályozó WIND1 gén nem aktív (18. ábra; Iwase és mtsai., 2017), a gyökérbe irányuló auxin transzport gátlása viszont kiváltja a WIND1 kifejeződését (18. ábra) HM közegben, ami feltehetően az endogén citokinin szint/érzékenység szabályozásán keresztül regenerációt tesz lehetővé átmeneti külső citokinin kezelés hatására. Kísérleteink arra is rávilágítottak, hogy a WIND1 transzkripciós faktor génjét a sebzés feltehetően éppen az endogén auxin transzport, illetve auxin szint megváltoztatásával indukálhatja.

Összességében elmondhatjuk, hogy rendszerünkben a hajtás, mint fő auxin forrás eltávolítása vágott gyökerek esetén, valamint az auxin transzport gátlása teljes növények esetén WIND1 expresszió emelkedését idézte elő (18. ábra), aminek eredményeképpen megnőtt a hajtás/kallusz/embrió regeneráció hatékonysága (4. táblázat). A sebzés gyökér explantumok citokinin-indukált hajtás/embrió regenerációjára gyakorolt hatása utánozható a hajtásból a gyökérbe irányuló auxin transzport gátlásával intakt növények gyökereiben. A hajtásból származó auxin valamilyen módon megzavarja tehát a gyökérben a külső citokinin kezeléssel kiváltott indirekt regenerációs folyamatokat, valamilyen módon csökkenti az intakt növények gyökerének regenerációs képességét, illetve ezirányú citokinin válaszát. Mindezen megfigyelések segíthetnek 
abban, hogy meghatározzuk azokat a kondíciókat, melyek segítik a gyökerekből kiinduló növényregeneráció indukcióját más fajok esetén is. 


\section{KÖSZÖNETNYILVÁNÍTÁS}

Szeretném őszinte hálámat és köszönetemet kifejezni elsőként csoportvezetőnknek, főnökömnek, Prof. Dr. Fehér Attilának, ki lehetővé tette, hogy kutatócsoportjában kezdhettem el a doktori fokozat megszerzéséhez vezető utat. Köszönöm támogatását, türelmét, szakmai segítségét elméletben és gyakorlatban egyaránt, mellyel végig kísérte munkámat.

Köszönetemet és tiszteletemet szeretném kifejezni mindkét témavezetőmnek, Prof. Dr. Fehér Attilának és Pichererné Dr. Gémes Katalinnak, köszönöm több éves útmutatásukat, tanításukat, a dolgozatommal kapcsolatos minden részletre kiterjedő és lelkiismeretes javítási munkájukat, javaslataikat.

Külön köszönettel és hálával tartozok Pichererné Dr. Gémes Katalinnak, „lab-anyának” a közös manuális és elméleti munkákért, a tapasztalatokért, hogy bármikor számíthattam rá szakmai és személyes vonatkozásban egyaránt, köszönöm mindig pozitív hozzáállását és ennek átadását.

Köszönöm Dr. Ormos Pál volt és Dr. Nagy Ferenc jelenlegi főigazgató, valamint Dr. Vass Imre igazgató uraknak, hogy a Szegedi Biológiai Központban biztosították munkámhoz a feltételeket.

Nagyon köszönöm opponenseimnek lelkiismeretes és precíz bírálati munkájukat, észrevételeiket, javaslataikat, amik hozzájárultak a dolgozatom végleges formájának kialakulásához, továbbá köszönettel tartozok a Doktori Bizottságom minden tagjának, hogy védésem lebonyolításához munkájukkal hozzájárultak.

Külön köszönetet szeretnék mondani Benkő Péternek a rendszer optimalizálása során általa végzett TIBA kezeléssel kapcsolatos kísérleteiért. Peti számos jó tanáccsal segítette további munkáimat és a kísérletek elvégzésekor mindig segítő kezet nyújtott.

Kaszler Nikolettnek is szeretnék hatalmas köszönetet mondani. Niki mindig önzetlenül állt/ült mellém munkám során, segített átlendülni személyes és szakmai akadályokon egyaránt. Külön köszönöm, hogy barátomként tekinthetek rá.

A „régi” Funkcionális Sejtbiológia csoport minden volt és jelenlegi tagjának (Dr. Valkai Ildikónak, Dr. Kenesi Erzsébetnek, Lajkó Dézinek, Ménesi Dalmának, Borbély Petinek, a legjobb laboránsnak, Nagy Rózának, valamint Koósné Majzik Hedvignek) köszönöm ötleteiket, hogy bármikor, bármilyen kérdéssel fordulhattam hozzájuk, továbbá hogy nekik köszönhetően mindig vidáman teltek a munkanapok.

Szintén szeretnék köszönetet mondani a „régi” Növényi Növekedés Molekuláris Szabályozása csoport korábbi és jelenlegi tagjainak, elsőként Dr. Magyar Zoltánnak, valamint Dr. Pettkó- 
Szandtner Aladárnak, Dr. Molnár Eszternek, Vaskó-Leviczky Tündének, Deli Mártának, Őszi Erikának, Dudásné Kovács Anitának, Nagy Viktornak.

A mikroszkópos kísérletek során nyújtott lelkiismeretes segítséget külön köszönöm Dr. Ferhan Ayaydinnak és a Mikroszkópos Sejtanalízis Laboratórium eddigi és jelenlegi kollégáinak, Kószó Zsuzsannának, Valkonyné Kelemen Ildikónak.

Köszönöm Dr. Domonkos Ildikónak a munkáját a lézeres pásztázó elektronmikroszkópos kísérleteknél.

Köszönöm Károlyi Mariannak a hivatalos ügyek mindig pontos, precíz intézését, Balla Mariannnak összes segítségét a laboratóriumi munkák zökkenőmentes lebonyolításához.

Köszönöm a Szegedi Tudományegyetem Növénybiológiai Tanszék munkatársainak a segítséget, külön köszönetem Dr. Mainé Dr. Csiszár Joláné, továbbá Dr. Gallé Ágnesé, Dr. Horváth Edité, Dr. Bela Krisztináé a RT-QPCR kísérleteknél adott segítségükért, Véseiné Dr. Szőllősi Rékáé a metszéseknél nyújtott segítségéért, valamint Dr. Kolbert Zsuzsannáé.

Öszinte hálával tartozom szüleimnek, kik gyermekkorom óta a tanulás szeretetére és a tudás iránti vágyra, annak tiszteletére neveltek. Támogatásuk, bíztatásuk az egyik legfontosabb motiváció számomra a mai napig. Köszönöm gondoskodásukat, türelmüket Ph. D. éveim alatt.

Külön köszönetet szeretnék mondani testvéremnek, Bernula Péternek, aki a közös pályaválasztásunknak köszönhetően a munkámmal kapcsolatos igen hasznos tanácsaival, meglátásaival járult hozzá jelenlegi munkámhoz és minden nap biztosította számomra a családi légkört a közös munkahelyi ebédek alkalmával. Külön köszönöm a dolgozatom hibáinak javítását neki.

Köszönöm Áginak, rokonaimnak, gyermekkori barátaimnak, Krisztinek és Szilvinek, az egyetemi évek során megismert nagyon kedves barátoknak, Németh Editnek, valamint közeli és távoli ismerőseimnek érdeklődésüket, lelkesítésüket.

Végül, de nem utolsósorban páromnak, Szekeres Ferencnek tartozok köszönettel, aki mindenben támogatott, továbbá nyugodt családi légkört biztosított dolgozatom elkészítésének ideje alatt.

A munkám elvégzését biztosító pályázatok az alábbiak voltak: NKFI-6 K 108802, GINOP-2.3.215-2016-00001. 


\section{IDÉZETT KÖZLEMÉNYEK}

1. Aida, M., Beis, D., Heidstra, R., Willemsen, V. A., Blilou, I., Galinha, C., Nussaume, L. és mtsai. (2004). The PLETHORA genes mediate patterning of the Arabidopsis root stem cell niche. Cell, 119:109-120.

2. Aida, M., Ishida, T., Tasaka, M. (1999). Shoot apical meristem and cotyledon formation during Arabidopsis embryogenesis: interaction among the CUP-SHAPED COTYLEDON and SHOOT MERISTEMLESS genes. Development, 126:1563-1570.

3. Andersen, S. V., Buechel, S., Zhao, Z., Ljung, K., Novák, O., Busch, W. és mtsai. (2008). Requirement of B2-type cyclin-dependent kinases for meristem integrity in Arabidopsis thaliana. Plant Cell, 20:88-100.

4. Aragão, V. P. M., de Souza Ribeiro, Y. R., Reis, R. S., Macedo, A. F., Floh, E. I. S., Silveira, V., Santa-Catarina, C. (2016). In vitro organogenesis of Cedrela fissilis Vell. (Meliaceae): the involvement of endogenous polyamines and carbohydrates on shoot development. Plant Cell Tiss Organ Cult, 124:611-620.

5. Atta, R., Laurens, L., Boucheron-Dubuisson, E., Guivarc'h, A., Carnero, E., Giraudat-Pautot, V. és mtsai. (2009). Pluripotency of Arabidopsis xylem pericycle underlies shoot regeneration from root and hypocotyl explants grown in vitro. Plant J, 57:626-644.

6. Bai, B., Su, Y. H., Yuan, J., Zhang, X. S. (2013). Induction of somatic embryos in Arabidopsis requires local YUCCA expression mediated by the down-regulation of ethylene biosynthesis. Mol Plant, 6:1247-1260.

7. Banno, H., Ikeda, Y., Niu, Q. W., Chua, N. H. (2001). Overexpression of Arabidopsis ESR1 induces initiation of shoot regeneration. Plant Cell, 13:2609-2618.

8. Basu, S. K., Datta, M., Sharma, M., Kumar, A. (2011). Haploid production technology in wheat and some selected higher plants. Australian Journal of Crop Science, 5(9):1087-1093.

9. Braybrook, S. A., Harada, J. J. (2008). LECs go crazy in embryo development. Trends Plant Sci, 13:624-630.

10. Braybrook, S. A., Stone, S. L., Park, S., Bui, A. Q., Lee, B. H., Fischer, R. L. és mtsai. (2006). Genes directly regulated by LEAFY COTYLEDON2 provide insight into the control of embryo maturation and somatic embryogenesis. Proc Natl Acad Sci USA, 103:3468-3473.

11. Bronner, R., Jeannin, G., Hahne, G. (1994). Early cellular events during organogenesis and somatic embryogenesis induced on immature zygotic embryos of sunflower (Helianthus annuus). Can J Bot, 72:239-248. 
12. Burgess, J. (1985). An introduction to plant cell development. Cambridge University Press Cambridge, pp. 129-153.

13. Capron, A., Chatfield, S., Provart, N., Berleth, T. (2009). Embryogenesis: Pattern Formation from a Single Cell. The Arabidopsis Book, pp. 1-28.

14. Casson, S. A., Lindsey, K. (2006). The turnip mutant of Arabidopsis reveals that LEAFY COTYLEDON1 expression mediates the effects of auxin and sugars to promote embryonic cell identity. Plant Physiol, 142:526-541.

15. Catterou, M., Dubois, F., Smets, R., Vaniet, S., Kichey, T., Van Onckelen, H. és mtsai. (2002). hoc: an Arabidopsis mutant overproducing cytokinins and expressing high in vitro organogenic capacity. Plant J, 30:273-287.

16. Charrière, F., Hahne, G. (1998). Induction of embryogenesis versus caulogenesis on in vitro cultured sunflower (Helianthus annuus L.) immature zygotic embryos: role of plant growth regulators. Plant Sci, 137:63-71.

17. Charrière, F., Sotta, B., Miginiac, É., Hahne, G. (1999). Induction of adventitious shoots or somatic embryos on in vitro cultured zygotic embryos of Helianthus annuus: variation of endogenous hormone levels. Plant Physiol Biochem, 37:751-757.

18. Chatfield, S. P., Capron, R., Severino, A., Penttila, P.-A., Alfred, S., Nahal, H., Provart, N. J. (2013). Incipient stem cell niche conversion in tissue culture: using a systems approach to probe early events in WUSCHEL-dependent conversion of lateral root primordia into shoot meristems. Plant J, 73:798-813.

19. Chaudhury, A. M., Letham, S., Craig, S., Dennis, E. S. (1993). amp1- a mutant with high cytokinin levels and altered embryonic pattern, faster vegetative growth, constitutive photomorphogenesis and precocious flowering. Plant J, 4:907-916.

20. Che, P., Gingerich, D. J., Lall, S., Howell, S. H. (2002). Global and hormone-induced gene expression changes during shoot development in Arabidopsis. Plant Cell, 14:2771-2785.

21. Che, P., Lall, S., Howell, S. H. (2007). Developmental steps in acquiring competence for shoot development in Arabidopsis tissue culture. Planta, 226:1183-1194.

22. Che, P., Lall, S., Howell, S. H. (2008). Acquiring competence for shoot development in Arabidopsis: ARR2 directly targets A-type ARR genes that are differentially activated by CIM preincubation. Plant Signal Behav, 3:99-101.

23. Che, P., Lall, S., Nettleton, D., Howell, S. H. (2006). Gene expression programs during shoot, root, and callus development in Arabidopsis tissue culture. Plant Physiol, 141(2):620-637.

24. Chen, J. T., Chang, W. C. (2004). TIBA affects the induction of direct somatic embryogenesis from leaf explants of Oncidium. Plant Cell Tiss Organ Cult, 79:315-320. 
25. Cheng, Z. J., Wang, L., Sun, W., Zhang, Y., Zhou, C., Su, Y. H. és mtsai. (2013). Pattern of auxin and cytokinin responses for shoot meristem induction results from the regulation of cytokinin biosynthesis by AUXIN RESPONSE FACTOR3. Plant Physiol, 161:240-251.

26. Chung, H. H., Chen, J. T., Chang, W. C. (2005). Cytokinins induce direct somatic embryogenesis of Dendrobium chiengmai pink and subsequent plant regeneration. Vitr Cell Dev Biol - Plant, 41:765-769.

27. Curaba, J., Moritz, T., Blervaque, R., Parcy, F., Raz, V., Herzog, M., Vachon, G. (2004). AtGA3ox2, a key gene responsible for bioactive gibberellin biosynthesis, is regulated during embryogenesis by LEAFY COTYLEDON2 and FUSCA3 in Arabidopsis. Plant Physiol, 136:3660-3669.

28. Daimon, Y., Takabe, K., Tasaka, M. (2003). The CUP SHAPED COTYLEDON genes promote adventitious shoot formation on calli. Plant Cell Physiol, 44:113-121.

29. Depta, H., Eisele, K. H., Hertel, R. (1983). Specific inhibitors of auxin transport - action on tissue segments and in vitro binding to membranes from maize coleoptiles. Plant Science Letters, 31:181-192.

30. Dong, J. Z., Dunstan, D. I. (1999). Cloning and characterization of six embryogenesisassociated cDNAs from somatic embryos of Picea glauca and their comparative expression during zygotic embryogenesis. Plant Mol Biol, 39:859-864.

31. Duclercq, J., Sangwan-Norreel, B., Catterou, M., Sangwan, R. S. (2011). De novo shoot organogenesis: From art to science. Trends Plant Sci, 16:597-606.

32. Dudits, D., Heszky, L. (2014). Szomatikus és géntechnológiai módszerek. In: Dudits, D. és Heszky, L. Növényi biotechnológia és géntechnológia. pp. 134-223. Agroinform Kiadó, Budapest.

33. Durgaprasad, K., Roy, M. V., Venugopal, M. A., Kareem, A., Raj, K., Willemsen, V., Mähönen, A. P. és mtsai. (2019). Gradient Expression of Transcription Factor Imposes a Boundary on Organ Regeneration Potential in Plants. Cell Reports, 29(8):453-463.

34. Elhiti, M., Stasolla, C. (2011). Ectopic expression of the Brassica SHOOT MERISTEMLESS attenuates the deleterious effects of the auxin transport inhibitor TIBA on somatic embryo number and morphology. Plant Sci, 180:383-390.

35. Endrizzi, K., Moussian, B., Haecker, A., Levin, J. Z., Laux, T. (1996). The SHOOT MERISTEMLESS gene is required for maintenance of undifferentiated cell in Arabidopsis shoot and floral meristem and acts at a different regulatory level than the meristem genes WUSCHEL and ZWILLE. Plant J, 10:967-979. 
36. Fehér, A. (2005). Why Somatic Plant Cells Start to form Embryos? In. Mujib, A., Samaj, J. (eds). Plant Cell Monographs (2). Somatic Embryogenesis. Springer-Verlag Berlin Heidelberg. pp. 85-101.

37. Fehér, A. (2015). Somatic embryogenesis - Stress-induced remodeling of plant cell fate. Biochimica et Biophysica Acta - Gene Regul Mech, 1849(4):385-402.

38. Fehér, A. (2019). Callus, Dedifferentiation, Totipotency, Somatic Embryogenesis: What These Terms Mean in the Era of Molecular Plant Biology? Front Plant Sci, 10:536.

39. Fehér, A., Bernula, D., Gémes, K. (2016). The Many Ways of Somatic Embryo Initiation. In: V.M. Loyola-Vargas, N. Ochoa-Alejo (Eds.), Somat. Embryog. Fundam. Asp. Appl., Springer International Publishing, Cham, 2016. pp. 23-37.

40. Fehér, A., Pasternak, T. P., Dudits, D. (2003). Transition of somatic plant cells to an embryogenic state. Plant Cell Tiss Organ Cult, 74:201-228.

41. Feldmann, K. A., Marks, M. D. (1986). Rapid and efficient regeneration of plants from explants of Arabidopsis thaliana. Plant Sci, 47:63-69.

42. Gaj, M. D. (2001). Direct somatic embryogenesis as a rapid and efficient system for in vitro regeneration of Arabidopsis thaliana. Plant Cell Tiss Organ Cult, 64:39-46.

43. Gaj, M. D. (2004). Factors influencing somatic embryogenesis induction and plant regeneration with particular reference to Arabidopsis thaliana (L.) Heynh. Plant Growth Regul, 43:27-47.

44. Gaj, M. D. (2011). Somatic embryogenesis and plant regeneration in the culture of Arabidopsis thaliana (L.) Heynh. immature zygotic embryos. Methods Mol Biol, 710:229-256.

45. Gaj, M. D., Zhang, S., Harada, J. J., Lemaux, P. G. (2005). Leafy cotyledon genes are essential for induction of somatic embryogenesis of Arabidopsis. Planta, 222: 977-988.

46. Gallois, J. L., Nora, F. R., Mizukami, Y., Sablowski, R. (2004). WUSCHEL induces shoot stem cell activity and developmental plasticity in the root meristem. Genes Dev, 18:375-380.

47. Galston, A. W. (1947). The effect of 2,3,5-triiodobenzoic acid on the growth and flowering of soybeans. American Journal of Botany, 34:356-360.

48. Gazzarrini, S., Tsuchiya, Y., Lumba, S., Okamoto, M., McCourt, P. (2004). The transcription factor FUSCA3 controls development timing in Arabidopsis through the hormones gibberellin and abscisic acid. Dev Cell, 7:373-385.

49. Gliwicka, M., Nowak, K., Balazadeh, S., Mueller-Roeber, B., Gaj, M. D. (2013). Extensive modulation of the transcription factor transcriptome during somatic embryogenesis in Arabidopsis thaliana. PLoS ONE 8 (2013), e69261. 
50. Gordon, S. P., Heisler, M. G., Reddy, G. V., Ohno, C., Das, P., Meyerowitz, E. M. (2007). Pattern formation during de novo assembly of the Arabidopsis shoot meristem. Development, 134:3539-3548.

51. Grzyb, M., Kalandyk, A., Mikuła, A. (2018). Effect of TIBA, fluridone and salicylic acid on somatic embryogenesis and endogenous hormone and sugar contents in the tree fern Cyathea delgadii Sternb. Acta Physiol Plant, 40(1):1-11.

52. Guillotin, B., Birnbaum, K. D. (2020). Just passing through: The auxin gradient of the root meristem. In: Curr Top in Dev Biol. Academic Press Inc., 2020.

53. Guo, Y., Chen, F., Zhang, F., Mi, G. (2005). Auxin transport from shoot to root is involved in the response of lateral root growth to localized supply of nitrate in maize. Plant Sci, 169:894900.

54. Hand, M. L., Koltunow, A. M. G. (2014). The Genetic Control of Apomixis: Asexual Seed Formation. Genetics, 197(2):441-450.

55. Heszky, L. (2003). Az ivaros szaporodás biotechnológiája. In: Dudits, D. és Heszky, L. (ed) Növényi biotechnológia és géntechnológia, pp. 57-96. Agroinform, Budapest.

56. Hibara, K., Takada, S., Tasaka, M. (2003). CUC1 gene activates the expression of SAM-related genes to induce adventitious shoot formation. Plant J, 36:687-696.

57. Horstman, A., Bemer, M., Boutilier, K. (2017). A transcriptional view on somatic embryogenesis. Regeneration, 4:201-216.

58. Huang, B. C., Yeoman, M. M. (1983). Formation of somatic embryos in tissue cultures of Arabidopsis thaliana. Arab Inf Service, 20:73-78.

59. Hwang, I., Sheen, J. (2001). Two-component circuitry in Arabidopsis cytokinin signal transduction. Nature, 413:383-389.

60. Ikeda, M., Ohme-Takagi, M. (2014). TCPs, WUSs, and WINDs: families of transcription factors that regulate shoot meristem formation, stem cell maintenance, and somatic cell differentiation. Front Plant Sci, 5:3-6.

61. Ikeda, Y., Banno, H., Niu, Q. W., Howell, S. H., Chua, N. H. (2006a). The ENHANCER OF SHOOT REGENERATION2 gene in Arabidopsis regulates CUP-SHAPED COTYLEDON1 at the transcriptional level and controls cotyledon development. Plant Cell Physiol, 47:1443-1456.

62. Ikeda, M., Umehara, M., Kamada, H. (2006b). Embryogenesis-related genes; Its expression and roles during somatic and zygotic embryogenesis in carrot and Arabidopsis. Plant Biotechnology, 23:153-161.

63. Ikeda-Iwai, M., Satoh, S., Kamada, H. (2002). Establishment of a reproducible tissue culture system for the induction of Arabidopsis somatic embryos. J Exp Bot, 53:1575-1580. 
64. Ikeda-Iwai, M., Umehara, M., Satoh, S., Kamada, H. (2003). Stress-induced somatic embryogenesis in vegetative tissues of Arabidopsis thaliana. Plant J, 34:107-114.

65. Ikeuchi, M., Iwase, A., Rymen, B., Lambolez, A., Kojima, M., Takebayashi, Y. és mtsai. (2017). Wounding triggers callus formation via dynamic hormonal and transcriptional changes. Plant Physiol, 175:1158-1174.

66. Ikeuchi, M., Ogawa, Y., Iwase, A., Sugimoto, K. (2016). Plant regeneration: cellular origins and molecular mechanisms. Development, 143:1442-1451.

67. Ikeuchi, M., Sugimoto, K., Iwase, A. (2013). Plant callus: mechanisms of induction and repression. Plant Cell, 25:3159-3173.

68. Inoue, T., Higuchi, M., Hashimoto, Y., Seki, M., Kobayashi, M., Kato, T. és mtsai. (2001). Identification of CRE1 as a cytokinin receptor from Arabidopsis. Nature, 409:1060-1063.

69. Ivanova, A., Velcheva, M., Denchev, P., Atanassov, A., Van Onckelen, H. (1994). Endogenous hormone levels during direct somatic embryogenesis in Medicago falcata. Physiol Plant, 92:8589.

70. Iwase, A., Harashima, H., Ikeuchi, M., Rymen, B., Ohnuma, M., Komaki, S. és mtsai. (2017). WIND1 promotes shoot regeneration through transcriptional activation of ENHANCER OF SHOOT REGENERATION1 in Arabidopsis. Plant Cell, 29:54-69.

71. Iwase, A., Mita, K., Nonaka, S., Ikeuchi, M., Koizuka, C., Ohnuma, M. H. és mtsai. (2015). WIND1-based acquisition of regeneration competency in Arabidopsis and rapeseed. J Plant Res, 128:389-397.

72. Iwase, A., Mitsuda, N., Koyama, T., Hiratsu, K., Kojima, M., Arai, T. és mtsai. (2011a). The AP2/ERF transcription factor WIND1 controls cell dedifferentiation in Arabidopsis. Curr Biol, 21:508-514.

73. Iwase, A., Ohme-Takagi, M., Sugimoto, K. (2011b). WIND1 A key molecular switch for plant cell dedifferentiation. Plant Signal Behav, 6:1943-1945.

74. Jiménez, V. M. (2001). Regulation of in vitro somatic embryogenesis with emphasis on to the role of endogenous hormones. R Bras Fisiol Veg, 13(2):196-223.

75. Jiménez, V. M. (2005). Involvement of Plant Hormones and Plant Growth Regulators on in vitro Somatic Embryogenesis. Plant Growth Regul, 47:91-110.

76. Jiménez, V. M., Bangerth, F. (2001a). Endogenous hormone concentrations and embryogenic callus development in wheat. Plant Cell Tiss Organ Cult, 67:37-46.

77. Jiménez, V. M., Bangerth, F. (2001b). Endogenous hormone levels in explants and in embryogenic and non-embryogenic cultures of carrot. Physiol Plant, 111:389-395. 
78. Jiménez, V. M., Bangerth, F. (2001c). Hormonal status of maize initial explants and of the embryogenic and non-embryogenic callus cultures derived from them as related to morphogenesis in vitro. Plant Sci, 160:247-257.

79. Jiménez, V. M., Thomas, C. (2006). Participation of plant hormones in determination and progression of somatic embryogenesis. In: Somatic Embryogenesis, A. Mujid és J. Samaj, szerk. (Berlin: Springer-Verlag), pp. 103-118.

80. Jung, J. H., Park, C. M. (2007). MIR166/165 genes exhibit dynamic expression patterns in regulating shoot apical meristem and floral development in Arabidopsis. Planta, 225:13271338.

81. Kagaya, Y., Toyoshima, R., Okuda, R., Usui, H., Hattori, T. (2005). LEAFY COTYLEDON1 controls seed storage protein genes through its regulation of FUSCA3 and ABSCISIC ACID INSENSITIVE3. Plant Cell Physiol, 46:399-406.

82. Kakimoto, T. (1996). CKI1, a histidine kinase homolog implicated in cytokinin signal transduction. Science, 274:982-985.

83. Kakimoto, T. (2001). Identification of plant cytokinin biosynthetic enzymes as dimethylallyl diphosphate: ATP/ADP isopentenyl transferases. Plant Cell Physiol, 42:677-685.

84. Kareem, A., Durgaprasad, K., Sugimoto, K., Du, Y., Pulianmackal, A. J., Trivedi, Z. B. és mtsai. (2015). PLETHORA genes control regeneration by a two-step mechanism. Curr Biol, 25:1017-1030.

85. Kareem, A., Radhakrishnan, D., Wang, X., Bagavathiappan, S., Trivedi, Z. B., Sugimoto, K., Prasad, K. (2016). Protocol: A method to study the direct reprogramming of lateral root primordia to fertile shoots. Plant Methods, 12:1-14.

86. Kasha, K. J., Hu, T. C., Oro, R., Simion, E., Shim, Y. S. (2001). Nuclear fusion leads to chromosome doubling during mannitol pretreatment of barley (Hordeum vulgare L.) microspores. J Exp Bot, 52:1227-1238.

87. Kikuchi, A., Sanuki, N., Higashi, K., Koshiba, T., Kamada, H. (2006). Abscisic acid and stress treatment are essential for the acquisition of embryogenic competence by carrot somatic cells. Planta, 223:637-645.

88. Kornet, N., Scheres, B. (2009). Members of the GCN5 histone acetyltransferase complex regulate PLETHORA-mediated root stem cell niche maintenance and transit amplifying cell proliferation in Arabidopsis. Plant Cell, 21:1070-1079.

89. Kroj, T., Savino, G., Valon, C., Giraudat, J., Parcy, F. (2003). Regulation of storage protein gene expression in Arabidopsis. Development, 130:6065-6073. 
90. Ledwoń, A., Gaj, M. D. (2009). LEAFY COTYLEDON2 gene expression and auxin treatment in relation to embryogenic capacity of Arabidopsis somatic cells. Plant Cell Rep, 28:1677-1688.

91. Ledwoń, A., Gaj, M. D. (2011). LEAFY COTYLEDON1, FUSCA3 expression and auxin treatment in relation to somatic embryogenesis induction in Arabidopsis. Plant Growth Regul, 65:157-167.

92. Lee, K., Park, O. S., Choi, C. Y., Seo, P. J. (2019). Arabidopsis TRITHORAX4 Facilitates Shoot Identity Establishment during the Plant Regeneration Process. Plant Cell Physiol, 60(4):826-834.

93. Leibfried, A., To, J. P., Busch, W., Stehling, S., Kehle, A., Demar, M. és mtsai. (2005). WUSCHEL controls meristem function by direct regulation of cytokinin-inducible response regulators. Nature, 438:1172-1175.

94. Lin, X., Hwang, G. J., Zimmerman, J. L. (1996). Isolation and characterization of a diverse set of genes from carrot somatic embryos. Plant Physiol, 112:1365-1374.

95. Liu, J., Hu, X., Qin, P., Prasad, K., Hu, Y., Xu, L. (2018). The WOX11-LBD16 pathway promotes pluripotency acquisition in callus cells during de novo shoot regeneration in tissue culture. Plant Cell Physiol, 59:734-743.

96. Liu, T., Reinhart, B. J., Magnani, E., Huang, T., Kerstetter, R., Barton, M. K. (2012). Of blades and branches: understanding and expanding the Arabidopsis ad/abaxial regulatory network through target gene identification. Cold Spring Harb Symp Quant Biol, 77:31-45.

97. Lotan, T., Ohto, M., Yee, K. M., West, M. A., Lo, R., Kwong, R. W. és mtsai. (1998). Arabidopsis LEAFY COTYLEDON1 is sufficient to induce embryo development in vegetative cells. Cell, 93:1195-1205.

98. Luo, Y., Koop, H. U. (1997). Somatic embryogenesis in cultured immature zygotic embryos and leaf protoplasts of Arabidopsis thaliana ecotypes. Planta, 202:387-396.

99. Mähönen, A. P., Higuchi, M., Törmäkangas, K., Miyawaki, K., Pischke, M. S., Sussman, M. R. és mtsai. (2006). Cytokinins regulate a bidirectional phosphorelay network in Arabidopsis. Curr Biol, 16:1116-1122.

100. Maraschin, S. F., De Priester, W., Spaink, H. P., Wang, M. (2005). Androgenic switch: an example of plant embryogenesis from the male gametophyte perspective. J Exp Bot, 417:1711-1726.

101. Márton, L., Browse, J. (1991). Facile transformation of Arabidopsis. Plant Cell Rep, 10(5):235-239. 
102. Mason, M. G., Mathews, D. E., Argyros, D. A., Maxwell, B. B., Kieber, J. J., Alonso, J. M. és mtsai. (2005). Multiple type-B response regulators mediate cytokinin signal transduction in Arabidopsis. Plant Cell, 17:3007-3018.

103. Mathur, J., Koncz, C., Szabados, L. (1995). A simple method for isolation, liquid culture, transformation and regeneration of Arabidopsis thaliana protoplasts. Plant Cell Rep, $14: 221-226$.

104. Matsuo, N., Makino, M., Banno, H. (2011). Arabidopsis ENHANCER OF SHOOT REGENERATION (ESR)1 and ESR2 regulate in vitro shoot regeneration and their expressions are differentially regulated. Plant Sci, 181:39-46.

105. Mayer, K. F. X., Schoof, H., Haecker, A., Lenhard, M., Jürgens, G., Laux, T. (1998). Role of WUSCHEL in regulating stem cell fate in the Arabidopsis shoot meristem. Cell, 95:805815.

106. Meinke, D. W., Franzmann, L. H., Nickle, T. C., Yeung, E. C. (1994). Leafy Cotyledon Mutants of Arabidopsis. Plant Cell, 6(8):1049-1064.

107. Meng, W. J., Cheng, Z. J., Sang, Y. L., Zhang, M. M., Rong, X. F., Wang, Z. W. és mtsai. (2017). Type-B ARABIDOPSIS RESPONSE REGULATORs Specify the Shoot Stem Cell Niche by Dual Regulation of WUSCHEL. Plant Cell, 29:1357-1372.

108. Michalczuk, L., Cooke, T. J., Cohen, J. D. (1992). Auxin levels at different stages of carrot somatic embryogenesis. Phytochemistry, 31(4):1097-1103.

109. Mujib, A., Ali, M., Tonk, D., Isah, T., Zafar, N. (2016). Embryogenesis in Ornamental Monocots: Plant Growth Regulators as Signalling Element. In: Somat. Embryog. Ornamentals Its Appl., Springer India, New Delhi, pp. 187-201.

110. Murashige, T., Skoog, F. (1962). A revised medium for rapid growth and bioassays with tobacco tissue cultures. Physiol Plant, 15:473-497.

111. Nawy, T., Lukowitz, W., Bayer, M. (2008). Talk global, act local - patterning the Arabidopsis embryo. Curr Opin Plant Biol, 11:28-33.

112. Negin, B., Shemer, O., Sorek, Y., Williams, L. E. (2017). Shoot stem cell specification in roots by the WUSCHEL transcription factor. PLoS ONE, 12(4), e0176093.

113. Nishiwaki, M., Fujino, K., Koda, Y., Masuda, K., Kikuta, Y. (2000). Somatic embryogenesis induced by the simple application of abscisic acid to carrot (Daucus carota L.) seedlings in culture. Planta, 211:756-759.

114. O'Neill, C. M., Mathias, R. J. (1993). Regeneration of plants from protoplasts of Arabidopsis thaliana L. cv. Columbia (C24), via direct embryogenesis. J Exp Bot, 44:15791585. 
115. Overbeek, J. V., Blondeau, R., Horne, V. (1951). Difference in activity between 2,4dichlorophenoxyacetic acid and other auxins, and its significance in herbicidal action. Plant Physiol, 26:687-696.

116. Ozawa, S., Yasutani, I., Fukuda, H., Komamine, A., Sugiyama, M. (1998). Organogenic reponses in tissue culture of srd mutants of Arabidopsis thaliana. Development, 125:135142.

117. Park, S. K., Kim, B. C., Chang, S. S., Choi, H. J., Lee, S. Y., Nam, H. G., Kim, D. U. (1993). Facile Transformation of Root Explants of Arabidopsis thaliana L. Heynh. with a Direct Shooting Medium. Mol Cells, 3(4):427-431.

118. Pasternak, T. P., Prinsen, E., Ayaydin, F., Miskolczi, P., Potters, G., Asard, H., Fehér, A. (2002). The Role of Auxin, pH, and Stress in the Activation of Embryogenic Cell Division in Leaf Protoplast-Derived Cells of Alfalfa 1. Plant Physiol, 129(4):1807-1819.

119. Pernisová, M., Klima, P., Horak, J., Valkova, M., Malbeck, J., Soucek, P. és mtsai. (2009). Cytokinins modulate auxin-induced organogenesis in plants via regulation of the auxin efflux. Proc Natl Acad Sci USA, 106:3609-3614.

120. Pernisová, M., Kuderová, A., Hejátko, J. (2011). Cytokinin and auxin interactions in plant development: metabolism, signalling, transport and gene expression. Curr Protein Pept Sci, 12:137-147.

121. Pillon, E., Terzi, M., Baldan, B., Mariani, P., Schiavo, F. L. (1996). A protocol for obtaining embryogenic cell lines from Arabidopsis. Plant J, 9:573-577.

122. Pulianmackal, A. J., Kareem, A. V., Durgaprasad, K., Trivedi, Z. B., Prasad, K. (2014). Competence and regulatory interactions during regeneration in plants. Front Plant Sci, $5(142): 1-16$

123. Raghavan, V. (2004). Role of 2,4-dichlorophenoxyacetic acid (2,4-D) in somatic embryogenesis on cultured zygotic embryos of Arabidopsis: Cell expansion, cell cycling, and morphogenesis during continuous exposure of embryos to 2,4-D. Am J Bot, 91(11):1743-1756.

124. Rashid, S. Z., Yamaji, N., Kyo, M. (2007). Shoot formation from root tip region: a developmental alteration by WUS in transgenic tobacco. Plant Cell Rep, 26:1449-1455.

125. Reed, R. C., Brady, S. R., Muday, G. K. (1998). Inhibition of auxin movement from the shoot into the root inhibits lateral root development in Arabidopsis. Plant Physiol, 118:1369-1378.

126. Reinert, J. (1959). Über die Kontrolle der Morphogenese und die Induktion von Adventiv embryonen an Gewebekulturen aus Karotten. Planta, 53:318-333. 
127. Reynolds, T. L. (1986). Somatic embryogenesis and organogenesis from callus cultures of Solanum carolinense. Am J Bot, 73:914-918.

128. Rider, S. D., Henderson, J. (2003). Coordinate repression of regulators of embryonic identity by PICKLE during germination in Arabidopsis. Plant J, 35:33-43.

129. Rihan, H. Z., Kareem, F., El-Mahrouk, M. E., Fuller, M. P. (2017). Artificial Seeds (Principle, Aspects and Applications). Agronomy, 7(4):71.

130. Rosspopoff, O., Chelysheva, L., Saffar, J., Lecorgne, L., Gey, D., Caillieux, E. és mtsai. (2017). Direct conversion of root primordium into shoot meristem relies on timing of stem cell niche development. Development, 144:1187-1200.

131. Sagare, A. P., Lee, Y. L., Lin, T. C., Chen, C. C., Tsay, H. S. (2000). Cytokinin-induced somatic embryogenesis and plant regeneration in Corydalis yanhusuo (Fumariaceae) - a medicinal plant. Plant Sci, 160:139-147.

132. Sakai, H., Honma, T., Aoyama, T., Sato, S., Kato, T., Tabata, S. és mtsai. (2001). ARR1, a transcription factor for genes immediately responsive to cytokinins. Science, 294:15191521.

133. Sang, Y. L., Cheng, Z. J., Zhang, X. S. (2018). Plant stem cells and de novo organogenesis. New Phytol, 218:1334-1339.

134. Sangwan, R. S., Bourgeois, Y., Dubois, F., Sangwan-Norreel, B. S. (1992). In vitro regeneration of Arabidopsis thaliana from cultured zygotic embryos and analysis of regenerates. J Plant Physiol, 140:588-595.

135. Santos-Mendoza, S. M., Dubreucq, B., Miquel, M., Caboche, M., Lepiniec, L. (2005). LEAFY COTYLEDON2 activation is sufficient to trigger the accumulation of oil and seed specific mRNAs in Arabidopsis leaves. FEBS Lett, 579:4666-4670.

136. Schaller, G. E., Bishopp, A., Kieber, J. J. (2015). The yin-yang of hormones: cytokinin and auxin interactions in plant development. Plant Cell, 27:44-63.

137. Schiavone, F. M., Cooke, T. J. (1987). Unusual patterns of somatic embryogenesis in the domesticated carrot: developmental effects of exogenous auxins and auxin transport inhibitors. Cell Differ, 21:53-62.

138. Scholl, R. L., May, S. T., Ware, D. H. (2000). Seed and Molecular Resources for Arabidopsis. Plant Physiol, 124:1477-1480.

139. Schoof, H., Lenhard, M., Haecker, A., Mayer, K. F., Jurgens, G., Laux, T. (2000). The stem cell population of Arabidopsis shoot meristems in maintained by a regulatory loop between the CLAVATA and WUSCHEL genes. Cell, 100:635-644. 
140. Servet, C., Conde, E., Silva, N., Zhou, D. X. (2010). Histone acetyltransferase AtGCN5/HAG1 is a versatile regulator of developmental and inducible gene expression in Arabidopsis. Mol Plant, 3:670-677.

141. Shang, B., Xu, C., Zhang, X., Cao, H., Xin, W., Hu, Y. (2016). Very-long-chain fatty acids restrict regeneration capacity by confining pericycle competence for callus formation in Arabidopsis. Proc Natl Acad Sci USA, 113(18):5101-5106.

142. Shin, J., Bae, S., Seo, P. J. (2020). De novo shoot organogenesis during plant regeneration. J Exp Bot, 71(1):63-72.

143. Skoog, F., Miller, C. O. (1957). Chemical regulation of growth and organ formation in plant tissues cultured in vitro. Symp Soc Exp Biol, 11:118-130.

144. Solís-Ramos, L. Y., Andrade-Torres, A., Sáenz Carbonell, L. A., Oropeza Salín, C. M., Castańo de la Serna, E. (2012). Somatic Embryogenesis in Recalcitrant Plants. In: Embryogenesis. Dr.Ken-Ichi Sato (Ed.), ISBN: 978-953-51-0466-7, InTech, Available from: http://www.intechopen.com/books/embryogenesis/somatic-embryogenesis-inrecalcitrant-plants

145. Song, Y. (2013). Insight into the mode of action of 2,4-dichlorophenoxyacetic acid (2,4-D) as an herbicide. J Integr Plant Biol, 56:106-113.

146. Sprunck, S., Baumann, U., Edwards, K., Langridge, P., Dresselhaus, T. (2005). The transcript composition of egg cells changes significantly following fertilization in wheat (Triticum aestivum L.). Plant J, 41:660-672.

147. Steward, F. C., Mapes, M. O., Mears, K. (1958). Growth and organized development of cultured cells. 11. Organization in cultures grown from freely suspended cells. Amer J Bet, 45:705-708.

148. Stone, S. L., Braybrook, S. A., Paula, S. L., Kwong, L. W., Meuser, J., Pelletier, J. és mtsai. (2008). Arabidopsis LEAFY COTYLEDON2 induces maturation traits and auxin activity: implications for somatic embryogenesis. Pro Natl Acad Sci USA, 105:3151-3156.

149. Stone, S. L., Kwong, L. W., Yee, K. M., Pelletier, J., Lepiniec, L., Fischer, R. L. és mtsai. (2001). LEAFY COTYLEDON2 encodes a B3 domain transcription factor that induces embryo development. Proc Natl Acad Sci USA, 98:11806-11811.

150. Su, Y. H., Liu, Y. B., Bai, B., Zhang, X. S. (2015). Establishment of embryonic shoot-root axis is involved in auxin and cytokinin response during Arabidopsis somatic embryogenesis. Front Plant Sci, 5(792):1-9. 
151. Su, Y. H., Su, Y. X., Liu, Y. G., Zhang, X. S. (2013). Abscisic acid is required for somatic embryo initiation through mediating spatial auxin response in Arabidopsis. Plant Growth Regul, 69:167-176.

152. Su, Y. H., Zhang, X. S. (2014). The hormonal control of regeneration in plants. Curr Top Dev Biol, 108:35-69.

153. Su, Y. H., Zhao, X. Y., Liu, Y. B., Zhang, C. L., O’Neill, S. D., Zhang, X. S. (2009). Auxin-induced WUS expression is essential for embryonic stem cell renewal during somatic embryogenesis in Arabidopsis. Plant J, 59:448-460.

154. Sugimoto, K. (2015). Plant cell reprogramming as an adaptive strategy. J Plant Res, 128:345-347.

155. Sugimoto, K., Jiao, Y., Meyerowitz, E. M. (2010). Arabidopsis regeneration from multiple tissues occurs via a root development pathway. Dev Cell, 18:463-471.

156. Sun, J., Niu, Q.-W., Tarkowski, P., Zheng, B., Tarkowska, D., Sandberg, G. és mtsai. (2003). The Arabidopsis AtIPT8/PGA22 gene encodes an isopentenyl transferase that is involved in de novo cytokinin biosynthesis. Plant Physiol, 131:167-176.

157. Suzuki, M., McCarty, D. R. (2008). Functional symmetry of the B3 network controlling seed development. Curr Opin Plant Biol, 11:548-553.

158. Terzi, M., Lo Schiavo, F. (1990). Somatic embryogenesis. In: BHAJWANI, S.S. (Ed.) Plant Tissue Culture: Applications and Limitations. Amsterdam, Elsevier, pp. 54-66.

159. Thomson, K. S., Hertel, R., Müller, S., Tavares, J. E. (1973). 1-N-naphthylphthalamic acid and 2,3,5-triiodobenzoic acid: In-vitro binding to particulate cell fractions and action on auxin transport in corn coleoptiles. Planta, 109:337-352.

160. Tian, X., Zhang, C., Xu, J. (2018). Control of Cell Fate Reprogramming Towards De Novo Shoot Organogenesis. Plant Cell Physiol, 59:713-719.

161. Touraev, A., Ilham, A., Vicente, O., Heberle-Bors, E. (1995). Stress-induced microspore embryogenesis in tobacco: an optimized system for molecular studies. Plant Cell Rep, 15:561-565.

162. Valvekens, D., Van Gysel, A., Van Montagu, M., Van Lijsebettens, M. (1995). Transformation of Arabidopsis thaliana Using Root Explants. In: Gene Transfer to Plants. Springer Berlin Heidelberg, Berlin, Heidelberg, pp. 5-10.

163. Valvekens, D., Van Montagu, M., Van Lijsebettens, M. (1988). Agrobacterium tumefaciens-mediated transformation of Arabidopsis thaliana root explants by using kanamycin selection. Proc Natl Acad Sci USA, 85:5536-5540. 
164. Venglat, S. P., Xiang, D., Kushalappa, K., Keller, W., Palmer, D., Selvara, G., Datla, R. (2005). OBPC Symposium: Maize 2004 \& Beyond Developmental and molecular genetics of embryogenesis in plants. In Vitro Cell Dev Biol - Plant, 41:378-387.

165. Vlachonasios, K. E., Thomashow, M. F., Triezenberg, S. J. (2003). Disruption mutations of ADA2b and GCN5 transcriptional adaptor genes dramatically affect Arabidopsis growth, development, and gene expression. Plant Cell, 15:626-638.

166. Wang, H., Guo, J., Lambert, K. N., Lin, Y. (2007). Developmental control of Arabidopsis seed oil biosynthesis. Planta, 226:773-783.

167. Wenck, R. A., Márton, L. (1995). Large scale protoplast isolation and plant regeneration of Arabidopsis thaliana. BioTechniques, 18:640-643.

168. Winter, D., Vinegar, B., Nahal, H., Ammar, R., Wilson, G. V., Provart, N. J. (2007). An "Electronic Fluorescent Pictograph" browser for exploring and analyzing large-scale biological data sets. PLoS One, 2:e718.

169. Wójcikowska, B., Jaskóła, K., Gąsiorek, P., Meus, M., Nowak, K., Gaj, M. D. (2013). LEAFY COTYLEDON2 (LEC2) promotes embryogenic induction in somatic tissues of Arabidopsis, via YUCCA-mediated auxin biosynthesis. Planta, 238(3):425-440.

170. Woodward, A. W., Bartel, B. (2005). Auxin: Regulation, action, and interaction. Ann Bot, 5:707-735.

171. Wu, Y., Haberland, G., Zhou, C., Koop, H. K. (1992). Somatic embryogenesis, formation of morphogenic callus and normal development in zygotic embryos of Arabidopsis thaliana in vitro. Protoplasma, 169:89-96.

172. Xu, L., Huang, H. (2014). Genetic and epigenetic controls of plant regeneration. Curr Top Dev Biol, 108:1-33.

173. Yarbrough, J. A. (1932). Anatomical and developmental studies of the foliar embryos of Bryophyllum calcynum. Am J Bot, 19:443-453.

174. Yazawa, K., Takahata, K., Kamada, H. (2003). Isolation of the gene that encodes carrot leafy cotyledon1 and expression analysis during somatic and zygotic embryogenesis. Plant Physiol Biochem, 42:215-223.

175. Yumbla-Orbes, M., da Cruz, A. C. F., Pinheiro, M. V. M., Rocha, D. I., Batista, D. S., Koehler, A. D. és mtsai. (2017). Somatic embryogenesis and de novo shoot organogenesis can be alternatively induced by reactivating pericycle cells in Lisianthus (Eustoma grandiflorum (Raf) Shinners) root explants. In Vitro Cell Dev Biol, 53:209-218. 
176. Zavattieri, M. A., Frederico, A. M., Lima, M., Sabino, R., Arnholdt-Schmitt, B. (2010). Induction of somatic embryogenesis as an example of stress-related plant reactions. Electron J Biotechnol, 13:1-9.

177. Zhang, S., Wong, L., Meng, L., Lemaux, P. G. (2002). Similarity of expression patterns of knotted1 and ZmLEC1 during somatic and zygotic embryogenesis in maize (Zea mays L.). Planta, 215:191-194.

178. Zhang, T. Q., Lian, H., Zhou, C. M., Xu, L., Jiao, Y., Wang, J. W. (2017). A Two-Step Model for de Novo Activation of WUSCHEL during Plant Shoot Regeneration. Plant Cell, 29:1073-1087.

179. Zhang, Z., Zhang, X. (2012). Argonautes compete for miR165/166 to regulate shoot apical meristem development. Curr Opin Plant Biol, 15:652-658.

180. Zhao, Y. (2014). Auxin biosynthesis. The Arabidopsis book / American Society of Plant Biologists 12, $\mathrm{e} 0173$.

181. Zheng, Q., Zheng, Y., Perry, S. E. (2013a). AGAMOUS-Like15 promotes somatic embryogenesis in Arabidopsis and soybean in part by the control of ethylene biosynthesis and response. Plant Physiol, 161:2113-2127.

182. Zheng, Q., Zheng, Y., Perry, S. E. (2013b). Decreased GmAGL15 expression and reduced ethylene synthesis may contribute to reduced somatic embryogenesis in a poorly embryogenic cultivar of Glycine max. Plant Signal Behav, 8:8-11.

183. Zimmerman, J. L. (1993). Somatic embryogenesis: a model for early development in higher plants. Plant Cell, 5:1411-1423.

184. Zimmerman, P. W., Hitchcock, A. E. (1942). Flowering habit and correlation of organs modified by triiodobenzoic acid. Contr Boyce Thompson Inst, 12:491-496.

185. Zuo, J., Niu, Q. W., Frugis, G., Chua, N. H. (2002). The WUSCHEL gene promotes vegetative-to-embryonic transition in Arabidopsis. Plant J, 30:349-359. 


\section{ÖSSZEFOGLALÁS}

Munkánk során célunk volt egy olyan in vitro gyökér alapú regenerációs kísérleti rendszer kidolgozása, mely lehetővé teszi az organogenezis és a SE kezdeti lépéseinek tanulmányozását és összehasonlítását Arabidopsis thaliana növényen. Ebben a rendszerben a regenerációs folyamatok vizsgálatához teljes csíranövényt, illetve gyökér explantumokat használtunk, melyeket szilárd táptalajon tenyésztettünk. Az oldalgyökér képződést auxinnal, a hajtásmerisztéma képződést pedig citokininnel indukáltuk. Ha auxin indukciót követően a gyökér explantumokat magas citokinin tartalmú táptalajon tartottuk, hajtás organogenezis történt. Ha azonban az auxin, majd citokinin indukciót követően egy megfelelő idő intervallumban (4 nap) a gyökereket hormonmentes tápközegre helyeztük, a gyökerek felületén közel 50-50\%-ban embriogén, illetve organogén eredetü regenerátumok is megjelentek. A SE folyamatát a trichómák meglétének hiánya az első leveleken (SE morfológiai markere), illetve az embriógenezisben részt vevő gének (LEC1, LEC2, FUS3) megnövekedett expressziója támasztotta alá. A SE további bizonyítékaként említendő, hogy a SEben gátolt lecl homozigóta mutáns gyökér explantumokat a vad típusú növényekhez hasonlóan kezelve/tenyésztve csupán hajtás organogenezist figyeltünk meg.

Eredményeink alapján feltételezzük, hogy a külsőleg alkalmazott citokinin megfelelő időben történő eltávolítása egyfajta átkapcsolást indukál a hajtás organogenezis és a SE útvonalak között. Hipotézisünk, hogy kezdetben hajtásregeneráció indukálódik, majd a citokinin eltávolítását követően a hajtás primordium embriószerü struktúrává transzdifferenciálódik, ám mivel a primordiumok fejlődése nem szinkronizált, nem mindegyik esetében tud lezajlani az átalakulás.

Érdekes módon, ha gyökér explantumok helyett a teljes növényeket folyamatosan magas citokinin tartalmú táptalajon (ARM IIr) tartottuk, azok gyökerei megvastagodtak, zöldültek, de esetükben sem kalluszképződést, sem hajtásképződést nem tapasztaltunk. Átmeneti citokinin indukció után hormonmentes táptalajra helyezve a növényeket még vastagodás, kalluszosodás sem történt. Mivel a teljes csíranövények gyökerével szemben a gyökér explantumok nagyfokú regenerációs képességet mutattak, figyelmünk a sebzés, valamint a hajtásból gyökérbe irányuló auxin transzport regenerációs folyamatokra gyakorolt hatásának vizsgálatára terelődött. Az epikotilhipokotil találkozási pontjára cseppentett auxin transzport inhibítor (TIBA, $5 \mu \mathrm{M}$ ) tartalmú agaróz csepp segítségével hormonmentes lemezeken tenyésztett teljes növények gyökerén is indukálható volt a regeneráció, a vágott gyökerekhez hasonlóan a regenerátumok közel fele embriogén eredetü volt. 
Az intakt növények gyökerével ellentétben, gyökér explantumokban a sebzés és a sebzés által indukált WIND1 transzkripciós faktor központi szerepet játszik a regenerációs potenciál megnövekedésében (Iwase és mtsai., 2015). Kísérleti rendszerünkben mind a hajtás - mint auxin forrás - eltávolítása, mind a hajtás-gyökér irányú auxin transzport TIBA kezelés általi blokkolása a teljes növények gyökerében megnövekedett WIND1 expressziót és fokozott kallusz/hajtás/embrióképződést eredményezett megfelelő induktív körülmények alatt. Az endogén, hajtás - gyökér irányú auxin transzport gátlása tehát imitálja a sebzés hatását (hajtás eltávolítása) a gyökerekből történő növényregenerálás során. A hajtásból származó auxin pedig valamilyen módon csökkenti az intakt növények gyökerének regenerációs képességét, illetve citokinin válaszát.

A kapott eredmények lehetővé teszik a növényi regenerációs folyamatok hátterében húzódó szabályozó mechanizmusok pontosabb megértését, ami pedig elvezethet a növények vegetatív szaporítását lehetővé tevő regenerációs rendszerek hatékonyságának növeléséhez gazdasági szempontból jelentős fajok esetében is. 


\section{SUMMARY}

Our aim was to establish an in vitro root-culture-based regeneration system to study the initiation steps of organogenesis and somatic embryogenesis in Arabidopsis thaliana. Whole seedlings or root explants were used in this system. To induce regeneration processes, low auxin concentration followed by a strong temporal cytokinin treatment was used. In a possible scenario, low auxin concentration induces the formation of lateral root primordia that starts to transdifferentiate into shoot meristem in the presence of cytokinin. If the root explants were kept on the medium containing cytokinin, organogenesis occurred. However, if the root explants were transferred onto a hormone-free medium at a right time (after 4 days), approximately half of the regenerated plantlets were formed through somatic embryogenesis.

The process of somatic embryogenesis was verified by the absence of trichomes on the first leaves (which is a morphological marker of somatic embryogenesis) and the enhanced expression level of three embryogenic marker genes (LEC1, LEC2, FUS3). Furthermore, culturing root explants of the embryogenesis-pathway-defective lecl mutant under the same culture regime only shoot organogenesis could be observed.

Based on our results, we hypothesize that timely removal of exogenously applied cytokinin is a very important factor in determining the regeneration pathway. Our hypothesis is that shoot regeneration is induced initially and after removal of cytokinin, the shoot primordia transdifferentiate into embryonic-like structures, but since the development of the shoot primordia is not synchronized, not all of them is competent for the transdifferentiation.

Interestingly, the above described regeneration system was inefficient when whole seedlings were used instead of root explants. Roots of whole seedlings cultured on high cytokinin medium thickened and became green but failed to regenerate calli and shoots. When the seedlings were removed to hormone-free medium after four-days cytokinin induction, even the thickening and greening of the root did not take place.

Root explants exhibit a high regeneration potential in contrast to the roots of whole seedlings. Therefore our attention turned to the role of wounding and the auxin transport from the shoot to the root on the regeneration processes. The potential role of shoot-derived auxin on the regeneration potential of the root was tested using the auxin transport inhibitor TIBA. $5 \mu \mathrm{M}$ TIBA in a low gelling temperature agarose drop was applied to the shoot-to-root junction of seedlings. TIBA application restored the regeneration potential of the seedling roots cultured on hormone-free medium, and nearly half of the regenerated plantlets formed through somatic embryogenesis. 
Wounding and the wound-induced expression of the WIND1 transcription factor are considered to have a central role in the increased regeneration potential of root explants (Iwase et al., 2015).

In our experimental system, both the removal of the shoot as an auxin source and the blocking of auxin transport from the shoot to the root by TIBA treatment resulted in increased WIND1 expression in the roots of whole seedlings in agreement with the increased competence for callus/shoot/embryo formation under appropriate inductive conditions. Thus, the effect of wounding on cytokinin-mediated shoot/embryo regeneration from roots could be mimicked by blocking the endogenous auxin transport from the shoot apex. The auxin transport from the shoot somehow reduces the regeneration ability and the cytokinin response of roots of intact plants.

The obtained results could help to better understand the regulatory background of plant regeneration processes making possible to set up more effective regeneration systems even in the case of economically relevant plant species. 


\section{SAJÁT KÖZLEMÉNYEK}

MTMT azonosító: 10051208

\section{Tudományos folyóiratcikkek}

\section{A dolgozat alapjául szolgáló közlemény (külföldi kiadású szakfolyóiratban):}

Bernula, D., Benkő, P., Kaszler, N., Domonkos, I., Valkai, I., Szőllősi, R., Ferenc, G., Ayaydin, F., Fehér, A., Gémes, K. (2020).

Timely removal of exogenous cytokinin and the prevention of auxin transport from the shoot to the root affect the regeneration potential of Arabidopsis roots.

Plant Cell Tiss Organ Cult, 140(2):327-339.

doi: 10.1007/s11240-019-01730-3

$\operatorname{IF}(2018): 2.200$

Egyéb közlemény (külföldi kiadású szakfolyóiratban):

Barna, B., Gémes, K., Domoki, M., Bernula, D., Ferenc, G., Bálint, B., Nagy, I., Fehér, A. (2018). Arabidopsis NAP-related proteins (NRPs) contribute to the coordination of plant growth, developmental rate, and age-related pathogen resistance under short days.

Plant Sci, 267:124-134.

doi:10.1016/j.plantsci.2017.11.006

Nyilvános idézők összesen: 3 Független: 3 Függő: 0 Idézett közlemények száma: 7

PMID: 29362091

IF(2018): 3.785

Egyéb közlemény (hazai kiadású szakfolyóiratban idegen nyelven):

Ördög, A., Bernula, D., Wodala, B. (2014).

The effect of xanthan gum as an elicitor on guard cell function and photosynthesis in Vicia faba. Acta Biologica Szegediensis, 58(1):21-26. 


\section{Könyvrészlet (idegen nyelvü):}

Fehér, A., Bernula, D., Gémes, K. (2016).

The Many Ways of Somatic Embryo Initiation. In: Loyola-Vargas VM, Ochoa-Alejo N (szerk.)

Somatic Embryogenesis: Fundamental Aspects and Applications. Dordrecht, Hollandia: Springer, (2016) pp: 23-37. (ISBN: 978-3-319-33704-3)

\section{Poszterek}

Borák, N., Ördög, A., Bernula, D., Wodala, B. (2014).

Photosynthetic activity of poplar lines under copper stress.

11th Congress of the Hungarian Society of Plant Biology, 27-29 August, 2014, Szeged, Biological Research Centre. BOOK OF ABSTRACTS, pp: 68.

Bernula, D., Fehér, A., Gémes, K. (2016).

In Vitro Somatic Embryogenesis on Arabidopsis Root Explants.

VISCEA International Conference - „Plant Cells in Vitro: Theory and Practice”, 8-9 February, 2016, Vienna. Programme and Abstracts, pp: 36.

Bernula, D., Fehér, A., Gémes, K. (2016).

In Vitro Somatic Embryogenesis on Arabidopsis Root Explants.

Fiatal Biotechnológusok Országos Konferenciája „FIBOK 2016”. 2016. március 21-22., Gödöllő, Szent István Egyetem. Program és összefoglalók, pp: 84.

Bernula, D., Gémes, K., Benkő, P., Domonkos, I., Ferenc, G., Ayaydin, F., Fehér, A. (2017). $\mathrm{Az}$ auxin gátolja a szomatikus embriógenezis folyamatát indukált Arabidopsis gyökéren.

A Magyar Növénybiológiai Társaság XII. Kongresszusa, 2017. augusztus 30.-szeptember 1., Szeged, Szegedi Biológiai Kutatóközpont. PROGRAM - ÖSSZEFOGLALÓK, pp: 42. (ISBN: 978963-12-9736-2)

Bernula, D., Gémes, K., Benkő, P., Domonkos, I., Ferenc, G., Ayaydin, F., Fehér, A. (2017). How to induce somatic embryogenesis in Arabidopsis roots?

STRAUB-DAYS, 24-25 May, 2017, Szeged, Biological Research Centre. 
Benkő, P., Bernula, D., Domonkos, I., Fehér, A., Gémes, K. (2018).

Inhibitory effect of auxin on plant regeneration from cytokinin-induced Arabidopsis roots.

STRAUB-DAYS, 10-11 May, 2018, Szeged, Biological Research Centre.

Benkő, P., Bernula, D., Domonkos, I., Fehér, A., Gémes, K. (2018).

In vitro somatic embryogenesis on Arabidopsis root explants. I. The role of hormones.

3rd National Conference of Young Biotechnologists, 28-29 March, 2018, Budapest, Eötvös Loránd University, Faculty of Science. Book of Abstracts, pp: 111.

Kaszler, N., Bernula, D., Szepesi, Á., Fehér, A., Gémes, K. (2018).

Role of polyamines during plant regeneration of Arabidospsis thaliana.

STRAUB-DAYS, 10-11 May, 2018, Szeged, Biological Research Centre.

Kaszler, N., Bernula, D., Szepesi, Á., Fehér, A., Gémes, K. (2018).

In vitro plant regeneration from Arabidopsis root explants. II. The effect of polyamines.

3rd National Conference of Young Biotechnologists, 28-29 March, 2018, Budapest, Eötvös Loránd University, Faculty of Science. Book of Abstracts, pp: 121.

Benkő, P., Fehér, A., Gémes, K., Bernula, D. (2019).

Somatic embryogenesis: inhibitory effect of shoot derived auxin on cytokinin-induced Arabidopsis roots.

VISCEA International Conference - „Plant Cells \& Tissues in Vitro”, 1-2 July, 2019, Vienna. Programme and Abstracts, pp: 27.

Kaszler, N., Bernula, D., Szepesi, Á., Fehér, A., Gémes, K. (2019).

Polyamines affected regeneration processes in Arabidopsis.

VISCEA International Conference - „Plant Cells \& Tissues in Vitro”, 1-2 July, 2019, Vienna. Programme and Abstracts, pp: 26.

\section{Egyéb közlemények}

Wodala, B., Borák, N., Bernula, D., Ördög, A. (2013).

Impact of PEG-induced osmotic stress on the photosynthesis of three Poplar lines studied by gasexchange, chlorophyll fluorescence and P700 absorbance. 
HUSRB/1002/214/036"OXIT", Characterization and oxidative stress tolerance in plants: from models to trees, BOOK OF FINAL REPORT, pp: 24-37.

Wodala, B., Borák, N., Bernula, D., Ördög, A. (2013).

Impact of zinc and copper stress onthe photosynthesis of three Poplar lines studied by gasexchange, chlorophyll fluorescence and P700 absorbance.

HUSRB/1002/214/036"OXIT", Characterization and oxidative stress tolerance in plants: from models to trees, BOOK OF FINAL REPORT, pp: 38-49. 


\section{Nyilatkozat}

Mint az alábbi közlemény felelős szerzője igazolom, hogy Bernula Dóra Ph. D. jelölt jelentős mértékben hozzájárult az alábbi tudományos publikáció létrehozásához és tézisében közölt eredményeit más $\mathrm{Ph}$. D. értekezésben nem használjuk fel:

Bernula, D., Benkő, P., Kaszler, N., Domonkos, I., Valkai, I., Szőllősi, R., Ferenc, G., Ayaydin, F., Fehér, A., Gémes, K. (2020).

Timely removal of exogenous cytokinin and the prevention of auxin transport from the shoot to the root affect the regeneration potential of Arabidopsis roots.

Plant Cell Tiss Organ Cult, 140(2):327-339.

doi: $10.1007 / \mathrm{s} 11240-019-01730-3$

IF(2018): 2.200

Szeged,

Pichererné Dr. Gémes Katalin egyetemi adjunktus Szegedi Tudományegyetem, Természettudományi és Informatikai Kar, Növénybiológiai Tanszék 